Ceotechnical En wronmential Aspects of Geothermal power Ceneration at hebers inperial valley, calfornta

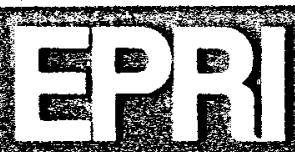

BPमा $=72299$

Project 580 Ioplct Heport 1 4opical heport 1

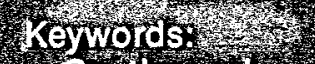
Geothermal capology ceophysics Hyarogeology 4.

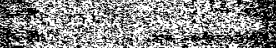

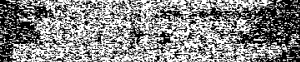
H.t. +6.

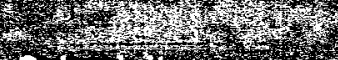
Seismicity Subsicence Environment

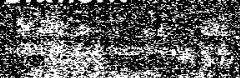

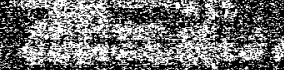

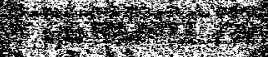
3ry

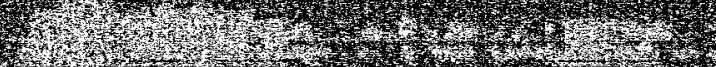

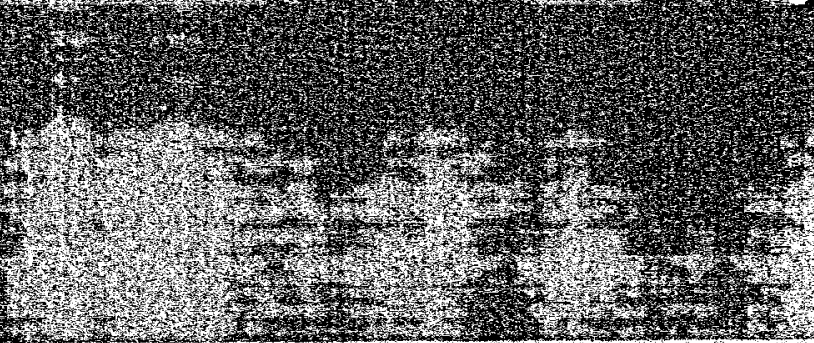

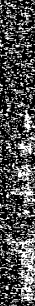




\section{DISCLAIMER}

This report was prepared as an account of work sponsored by an agency of the United States Government. Neither the United States Government nor any agency Thereof, nor any of their employees, makes any warranty, express or implied, or assumes any legal liability or responsibility for the accuracy, completeness, or usefulness of any information, apparatus, product, or process disclosed, or represents that its use would not infringe privately owned rights. Reference herein to any specific commercial product, process, or service by trade name, trademark, manufacturer, or otherwise does not necessarily constitute or imply its endorsement, recommendation, or favoring by the United States Government or any agency thereof. The views and opinions of authors expressed herein do not necessarily state or reflect those of the United States Government or any agency thereof. 


\section{DISCLAIMER}

Portions of this document may be illegible in electronic image products. Images are produced from the best available original document. 


\title{
GEOTECHNICAL ENVIRONMENTAL ASPECTS OF GEOTHERMAL POWER GENERATION AT HEBER, IMPERIAL VALLEY, CALIFORNIA
}

\author{
EPRI ER-299 \\ (Research Project 580) \\ Topical Report I \\ October 1976 \\ Prepared by \\ Geonomics, Inc. \\ 3165 Adeline Street \\ Berkeley, California 94703
}

Prepared for

Electric Power Research Institute

3412 Hillview Avenue

Palo Alto, California 94304

Project Manager

Vasel W. Roberts 


\section{LEGAL NOTICE}

This report was prepared by Geonomics, Inc. for Holt/Procon, as an account of work sponsored by the Electric Power Research Institute, Inc. (EPRI). Neither EPRI, members of EPRI, Geonomics, Inc. for Holt/Procon, nor any person acting on behalf of either: (a) makes any warranty or representation, express or implied, with respect to the accuracy, completeness, or usefulness of the information contained in this report, or that the use of any information, apparatus, method, or process disclosed in this report may not infringe privately owned rights; or (b) assumes any liabilities with respect to the use of, or for damages resulting from the use of, any information, apparatus, method, or process disclosed in this report. 
ABSTRACT

This report presents a portion of the results from a one-year feasibility study sponsored by the Electric Power Research Institute (EPRI) to assess the feasibility of constructing a 25-50 MWe geothemal power plant using low salinity hydrothermal fluid as the energy source.

The impact of power generation from hydrothemal resources on subsurface water flow, seismicity and subsidence are of acute interest in the determination of the environmental acceptance of geothermal energy. At the same time, the experience and data bases in these areas are very limited.

The objective of the project was to assess the technical, geotechnical, environmeñtal and economic feasibility of producing electricity from hydrothermal resources like those known to exist in the United States. The objective of this part of the study was to investigate the geotechnical aspects of geothermal power generation and their relationship to environmental impacts in the Imperial Valley of California.

This report discusses geology, geophysics, hydrogeology, seismicity and subsidence in terms of the availability of data, state-of-the-art analytical techniques, historical and technical background and interpretation of current data. It also discusses estimates of the impact of these geotechnical factors on the enviramment in the Imperial Valley, if geothermal development proceeds. 
The following reports from this same study are being considered for publication by EPRI:

- "Comparison of Hydrothemal Reservoirs in the Western United States"

- $\quad$ "Reservoir Engineering and Aspects of Geothermal Site Selection at Heber, California and Valles Caldera, New Mexico"

- "Energy Conversion and Economics for Geothermal Power Generation at Heber, California; Valles Caldera, New Mexico; and Raft River, Idaho - Case Studies"

- "Preliminary Environmental Assessments of Geothermal Power Generation at Heber, California"

- Geotechnical Environmental Aspects of Geothermal Power Generation at Heber, California"

- Socioeconomic Environmental Aspects of Geothermal Power Generation at Heber, California" 


\section{TABLE OF CONTENTS}

\begin{tabular}{lc} 
List of Figures & Page \\
List of Tables & vii \\
Summary & xi \\
General Setting & xiii \\
Geology and Geophysics & 1 \\
Hydrology & 5 \\
Seismicity and Subsidence & 18 \\
\hline Conclusions and Recommendations & 28 \\
Bibliography & 71 \\
\hline
\end{tabular}




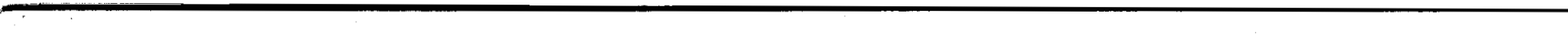




\section{IIST OF FIGURES}

Number

Page

1 Regional Setting of the Imperial Valley

2 General Geologic Map of the Ifperial Valley

3 Depth to Basement Isopach Map

4 Bouguer Gravity for the Imperial Valley

5 Crustal Gravity Modeling Across the Imperial Valley

6 Tectonic Setting of the Salton Trough

7 Schematic Model for the Evolutionary Development of the Salton. Trough

8. Thermal Gradient Map of the Imperial Valley

9 Electrical Resistivity Map for the Valley

10 East-West Resistivity Cross Section from Heber to Yuma

11 Location of Earthquake Epicenters in the Imperial Valley for the Period June 1, 1973 Through May 31, 1974

12 Network of Benchmarks Established in 1970 During the U.C. - Riverside, Imperial Valley Geothermal Project

13 Network of First Order Vertical Control and 2-Year Change in Elevation, 1972-1974

14 Geothermal Areas of Local Vertical and Horizontal Control

15 California-Nevada Earthquakes, Magnitude 6 and Over, 1903-1956

16 Iarge Earthquakes in the California Region

17 Epicenters of Earthquake Events in Southern California 36 of Magnitude 4 or Greater from 1932 Through 1972 


\section{IIST OF FIGURES}

Number

Page

18 Imperial Valley Earthquake, 1940. Map Showing Iocation of Fault, Instrumental Epicenter, Etc.

19 Seismographic Stations in Northern Baja California, Mexico (FHM, EGM, SFP) and Southermmost Stations of Cal Tech Network in Sauthern California (BAR, GIA)

20 Vertical Distribution of Hypocenters for Earthquakes Occurring Along the Brawley Fault

21 Epicenters of Earthquakes of the Brawley Swarm, January 1975

22 Depths of Earthquake Hypocenters' for Events of the Brawley Swarm, January 1975

23 Epicenters of Injection-Induced Earthquakes at Rangely, Colorado

24 Smoothed Strain Release Map of Southern California from 1933 Through 1963

25 Recurrence Curve for Earthquakes in the Imperial Valley Region, 1933-1972

26 Attenuation of Maximum Rock Acceleration with Increasing Distance from Causative Fault, $M=6.5$

27 Attenuation of Maximu Rock Acceleration with Increasing Distance from Causative Fault, $M=7.0$

28 Attenuation of Maximum Rock Acceleration with Increasing Distance from Causative Fault, $M=7.5$

29 Attenuation of Maximum Rock Acceleration with Increasing Distance from Causative Fault, $M=8.0$

30 Variation of Maximum Acceleration with Earthquake Magnitude and Distance from Causative Fault

31 Ground Accelerations Recorded at El Centro (N-S

Component) in El Centro Earthquake of 1940 


\section{IIST OF FIGURES}

Number

Page

32 Comparison of Maximum Acceleration in Rock

59 and Stiff Soil Deposits for Earthquake Magnitude 7

61

33 Ranges of Maximm Accelerations in Rock

62

34 Attenuation Equations for Magnitude 6.5 Compared to Data from Strong Mbtion Stations Recording San Fernando Earthquake - February 9, 1971.

35 Geodetic Measurement in the Imperial Valley from 1934 to 1967 


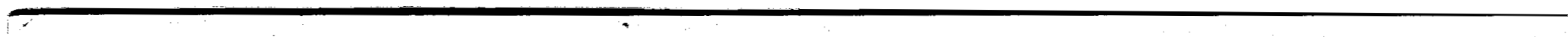




\section{LIST OF TABLES}

Number

Page

1 Average Colorado River Water at Lake Havasu 22

2 Basin-Edge Waters (East Mesa) 22

3. Average Shallow Inperial Valley Water 22

4. Typical Geothermal Brine, Mesa 6-1 22

5 Salton Sea Brines Hypersaline Brine.at the Shell 23 IID No. 2 Well

6. Chemical Quality of Water, Heber Geothermal 25 Reservoir - Imperial Valley, California

7 Analysis of Geothermal Water fram Cerro Prieto, 26 B.C. , Mexio 

SUMMARY

The objective of the "Feasibility study for a Iow Salinity Hydrothermal Plant" was to assess the technical, geotechnical, economic and environmental feasibility of constructing a $50 \mathrm{MWe}$ demonstration plant for a low salinity hydrothemal reservoir and to describe the environmental impacts of such a facility. At this point, the Heber, California site has been recommended to the Electric Power Research Institute (EPRI) as the most feasible location for the geothermal plant. The binary process has been recommended as the most feasible conversion process.

This report discusses the Imperial Valley with regand to:

- Geology and Geophysics

- Hydrogeology

- Seismicity and Subsidence

The Imperial valley is an area of high regional heat flow, intensive crustal deformation, high seismicity and subsidence and numerous geothermal anomalies. It is one of the most seismically active areas in the United states. The sediments at the Heber Anomaly are dominantly Quatenary deltaic sands and shales derived from Colorado River sources and persist to a depth of $2.5 \mathrm{~km}$ $(8,203 \mathrm{ft})$. The basement at Heber is at a depth of approximately $7 \mathrm{~km}$ $(22,967 \mathrm{ft})$.

The Imperial Fault separates brackish central valley waters from fresher waters to the east and thus explains some of the incomplete groundwater mixing. Deep clay deposits separate shallow and deep groundwater systems 
and tend to make the central valley waters saltier and more stagnant than eastern or western waters. It has also been noted that artesian waters exist only east of the Alamo River.

With regard to chemical constituents, the principal Imperial Valley waters can be categorized as:

- Basin-edge waters which strongly resemble Colorado River source waters

- Shallow Central Valley waters which are somewhat more saline and richer in carbonate

- Deep valley waters which tend to be more saline but resemble basin-edge waters in ionic ratio

- Hydrothermal water which tends to have elevated silica, $\mathrm{pH}$, metal salts and salinity

- Hypersaline geothermal brines which contain unusually high salinities and are confined to the Salton Buttes.

The geothermal brines of the Imperial Valley do not differ greatly from deep waters in the area except for the addition of metal salts and the dissolution of carbonates. The shallow groundwater at Heber is vastly different from the deeper hydrothermal waters which is probably due to the presence of the clay cap rock. Geothermal waters are produced at a depth of 600 to 1,900 m $(1,968$ to $6,232 \mathrm{ft})$ with sodium chloride being the dominant dissolved constituent. The pH of these waters varies from 6.8 to 7.4. Silica concentrations are low enough to avoid scaling at the well bore and surface pipes. Trial production and injection operations at Heber have not shown any corrosion or scaling problems to date.

It has been estimated that between 50 to 60 producing wells and 20 to 30 injection wells will be required for a 200 MWe net electricity plant at 
Heber. A development of this nature could alter the underground water flow pattern. However, considering the effective hydrologic separation between the geothermal reservoir and the shallow groundwater system at Heber, the only likely changes are the diversion of deep water from other areas and increased salinity of deep aquifers through salt water reinjection. The projected extent of such changes is minor.

Only traces of hydrogen sulfide have been reported from wells and the amount of other nonoondensable gases in the Heber geothermal water is minimal. However, this is not the case with the noncondensable gases at the Cerro Prieto, Mexico geothermal facility which contains $\mathrm{CO}_{2}$ and $\mathrm{H}_{2} \mathrm{~S}$ concentrations of $1,000 \mathrm{ppm}$ and $300 \mathrm{ppm}$, respectively.

The United States Geological Survey (U.S.G.S.) and California Institute of Technology (Cal Tech) have permanent seismic monitoring stations located throughout the Imperial Valley. These organizations also have portable seismic monitoring equipment that can be moved to an area after a large magnitude event and record the sequence of after-shocks. Chevron oil Company plans to establish a closely spaced seismic net to gather information on background seismicity and the relationship the proposad geothermal production might have on seismic activity. This project is scheduled to begin in 1975 and will run continuously throughout the period of power production.

The U.S. Coast and Geodetic Survey in cooperation with the U.S.G.S. has developed an extensive program to monitor ground motion through the Imperial Valley. This program calls for triangulation and leveling surveys throughout the valley every two years and more frequently if geothermal production 
becomes a reality in the valley. In addition, a private leveling survey was completed by Chevron Oil Company in the Heber area. The 1974-1975 survey measured the relative elevation change in the Heber area for a period of one year.

As stated previously, the Imperial Valley is characterized by a high level of seismic activity and a large amount of strain release. Since 1900, 12 earthquakes have registered greater than Magnitude 6 on the Richter Scale. A large concentration of seismic events has occurred in the Salton Trough along faults of the San Andreas System. Smaller shocks and earthquake swarms are also very common for faults in the San Andreas System. The Imperial Valley fault system is moving right laterally at the cumulative rate of approximately $8.0 \mathrm{~cm} / \mathrm{yr}(3.1 \mathrm{in} / \mathrm{yr})$. This is a 20-year average and is by no means occurring at a constant rate. Earthquakes occurring along the San Andreas Fault System typically have focal depths of 5-8 km (3-5 mi), which is approximately the basement-sediment interface. A limiting depth for hypocenters in the valley is about 12-15 km (6-9 mi) because at depths greater than this, sufficiently high temperatures cause the rocks to move plastically in response to stress. In the geothermal areas of the valley, this limiting depth is lower.

Several studies have shown that there is a correlation between microearthquake activity and geothermal anomalies. In the Imperial valley, the correlation is unusually high. High levels of microearthquake activity are found at Salton Buttes, North Brawley and East Mesa. To date, it is unknown whether such a relationship also exists at Heber. In any case, several remarks can be made about earthquakes in the Valley's geothemal areas: 
- Shocks are generally smaller in magnitude and more frequent in geothermal areas than other areas in the same tectonic setting.

- Faults related to the microearthquakes may serve as conduits for circulating brines. At the Salton Buttes, for example, it was observed that $\mathrm{CO}_{2}$ wells began emitting large quantities of gas just after earthquakes in the 1930's.

- Earthquake focal depths are usually shallower in geothermal areas than in areas outside, implying that microearthquakes are related to geothermal processes. Also, the amplitude of earthquakes within geothermal areas appears to be smaller than outside.

The possibility of triggering earthquakes by geothermal production and reinjection is of same concem. Although existing producing fields at the Geysers, California and Wairakei, New Zealand have long been associated with earthquake activity, production has not been hampered by earthquakes and no associations have been drawn between geothermal production and earthquake activity. Regional tectonics, the stress field and the rock properties at Heber are vastly different from those areas that have experienced earthquakes due to fluid injection fram oil field and waste injection wells.

In the Heber area the effect that production might have on earthquake activity may only be speculated. Withdrawal of fluids may alter the deep groundwater pattern and perhaps even the surface flow rate. The effect of these alterations on the tectonic stress regime is unknown. Any attempt to determine these effects, and the effects of fluid reinjection, will require several years of continuous seismic and geodetic monitoring during which background seismicity and the location of active faults must be established. 
The Imperial Valley is an area of high regional strain release and the Heber area is part of this high belt. The Heber region could expect between 64 and 256 equivalent Magnitude 3 earthquakes every 30 years. The same amount of strain would be released by 10-40 Magnitude 4, 2-10 Magnitude 5 or 0.25 to 2.0 Magnitude 6 earthquakes, or by aseismic creeping. Adequate data do not exist on the local stress pattern and the strength of the formation at Heber to allow predictions regarding possible injection-induced seismicity. However, it appears unlikely that injection of waste brine will significantly increase seismicity in the Heber area; no faults have been detected as yet under Heber and the increase in pore pressure around injection wells will not be excessive because of the relatively high permeability of the Heber reservoir. If a major earthquake cccurs, it will most likely occur along one of the major active faults in the area. The location of the more active faults with respect to the proposed plant location is as follows:

\begin{tabular}{lc}
\multicolumn{1}{c}{ Fault } & Distance to Plant Site, km (mi) \\
\cline { 2 - 3 } Imperial & $11(6.8)$ \\
Brawley & $23(14.3)$ \\
San Andreas & $38(23.6)$ \\
Elsinore & $27(16.8)$ \\
San Jacinto & $6.5(4.0)$
\end{tabular}

The Imperial county and the Los Angeles County Building codes recommend a design acceleration of $0.25 \mathrm{~g}$ for an area classified as Zone 3 (high seismic hazard). According to those codes, the Heber area is classified as Zone 3. However, the U.S. Department of the Anmy publication "Seismic Design of Buildings" defines Heber as a class 4 (extremely hazardous) area and recommends that buildings be designed for an acceleration of $0.375 \mathrm{~g}$. This design is 50 percent more conservative than that required by the Imperial 
County regulations. Due to the proximity of these faults to the proposed plant site, the more conservative design criteria of $0.375 \mathrm{~g}$ seems to be justified.

Ground subsidence and lateral movement have been observed at other sites where fluid withdrawal has not been acocmpanied by fluid reinjection. In the Imperial Valley, however, ground motion and subsidence exist as part of the tectonic background. The valley is moving horizontally in a complex manner with the central portion of the Valley subsiding at a rate of about $1.5 \mathrm{~cm}$ (0.6 in) per year relative to the surrounding mountains. A recent leveling survey by Chevron Oil Company suggests that the Heber area is moving up slightly with respect to El Centro, but the dominant motion has been a downward tilting northward and eastward. Land subsidence problems related to the proposed geothermal development at Heber can only be speculated at this time. Because of the fact that the geothermal fluid would be reinjected after heat extraction, any subsidence due to brine production is likely to be small and most likely no larger than that due to tectonic causes. The effect of subsidence is not likely to prove a significant enviromental concern.

At this time, reliable estimates of future subsidence in the area of the Heber geothermal reservoir cannot be made until the reservoir has been operated for a period of time and the corresponding land survey results studied. Without this information, results from computer models are considered to be the next best source of information available, provided that the input reservoir parameters properly represent the reservoir. 
There are other means for estimating future subsidence. One such method has been developed by Geertsma and by Raghaven and Miller. In operating the Heber reservoir, the rate of fluid injection and fluid production will be the same and the overburden pressure has been assumed to be fixed. Geonomics has indicated in the past that the reservoir pressure drop due to the production of water for a $200 \mathrm{Mwe}$ plant will be on the order of 6.8 - 20.4 atm (100-300 psia) around the well bores. Away from the wells, the pressure drop will be much smaller. An average pressure drop for the entire reservoir should be less than $6.8 \mathrm{~atm}$ (100 psia). The overall net productive thickness of the reservoir has been assumed to be $734 \mathrm{~m}(2,408 \mathrm{ft})$. Using these data, the compaction was estimated at $0.12 \mathrm{~m}(0.4 \mathrm{ft})$. Assuming the reservoir has the shape of a cylindrical disc of constant thickness with its axis vertical and without considering the variation of drawdown pressures with respect to time or for any time lag in subsidence, the subsidence has been estimated to be $0.21 \mathrm{~m}(0.7 \mathrm{ft})$. Considering the gross assumptions that have been used, these values are at best only an indication of the possible true magnitude and should be considered to be conservative. The true average value is probably less. The subsidence possibility is minimal over most of the reservoir, but localized subsidence around the producing wells can be significant.

As a result of the above study, the following conclusions and recommendations can be made:

- Geothermal development at Heber is not likely to have any adverse impact on the shallow groundwater resource of the area. 
- Corrosion, scaling and presence of noncondensable gases should prove to be minimal for the Heber geothermal project.

- The Heber area lies in a general region of high seismicity and strain release.

- No fault has yet been mapped directly under the Heber area. The stress condition and the strength of the rocks at Heber are not known. Until such data are available, it is difficult to assess the possibility of increased seismicity due to geothermal activity.

- The Heber area is subsiding and tilting northeastward due to tectonic causes. The fluctuating subsidence rate is not great and should present no serious problems.

- Geothemal development activity at Heber should have a small effect on subsidence compared to that due to existing tectonic causes.

- Design of the structures should incorporate acceleration and resonance spectra which are available for the 1940 earthquake. A combined local soil test analysis and seismic structural response should be made as part of any detailed structural design. The design acceleration should not be less than $0.375 \mathrm{~g}$.

- Baseline data should be obtained by monitoring the Heber area for seismicity and subsidence before power production begins. It is also desirable to have a permanent monitoring system throughout the life of the power plant. 
GENERAL SETTING

The Heber geothermal prospect lies in the south-central Imperial Valley of southeastem California (Figure No. 1). This valley forms a part of a broad elongate, northwest-trending depression in southern california and Mexico called the Salton Trough. Some $250 \mathrm{~km}$ (155 mi ) long and 30 to $70 \mathrm{~km}$ (19 to $44 \mathrm{mi}$ ) wide, the Salton Trough ranges in elevation from $50 \mathrm{~m}$ (164 ft) at The Colorado River Delta near the international border to $-75 \mathrm{~m}$ (-246 ft) at the Salton Sea. Bordering the trough to the west are the $1.5 \mathrm{~km}(4,922 \mathrm{ft})$ high Peninsular Ranges while to the east lie the $0.5-1.0 \mathrm{~km}(1,641-3,281 \mathrm{ft})$ high Chocolate and Orocopia Mountains; the Gulf of California is to the south and the San Bernardino Mountains are located to the north.

The Imperial valley is a gently northwand-sloping valley surficially covered with playa deposits in its center and alluvial fans and aeolian dumes on its flanks. It lies largely below sea level and is protected from the filf of California waters by the natural dam formed by the Colorado River Delta. The naturally arid valley was transformed into a rich agricultural district at the turn of the century by the introduction of colorado River water through an extensive system of irrigation canals. The northern end of the valley, which is the lowest part of the depression, contains a $1,200 \mathrm{sq} \mathrm{km}$ (463 sq $\mathrm{mi}$ ) body of saline water, generally less than $4.6 \mathrm{~m}$ (15 ft) deep, called the Salton Sea. The sea was formed in 1905 when a 


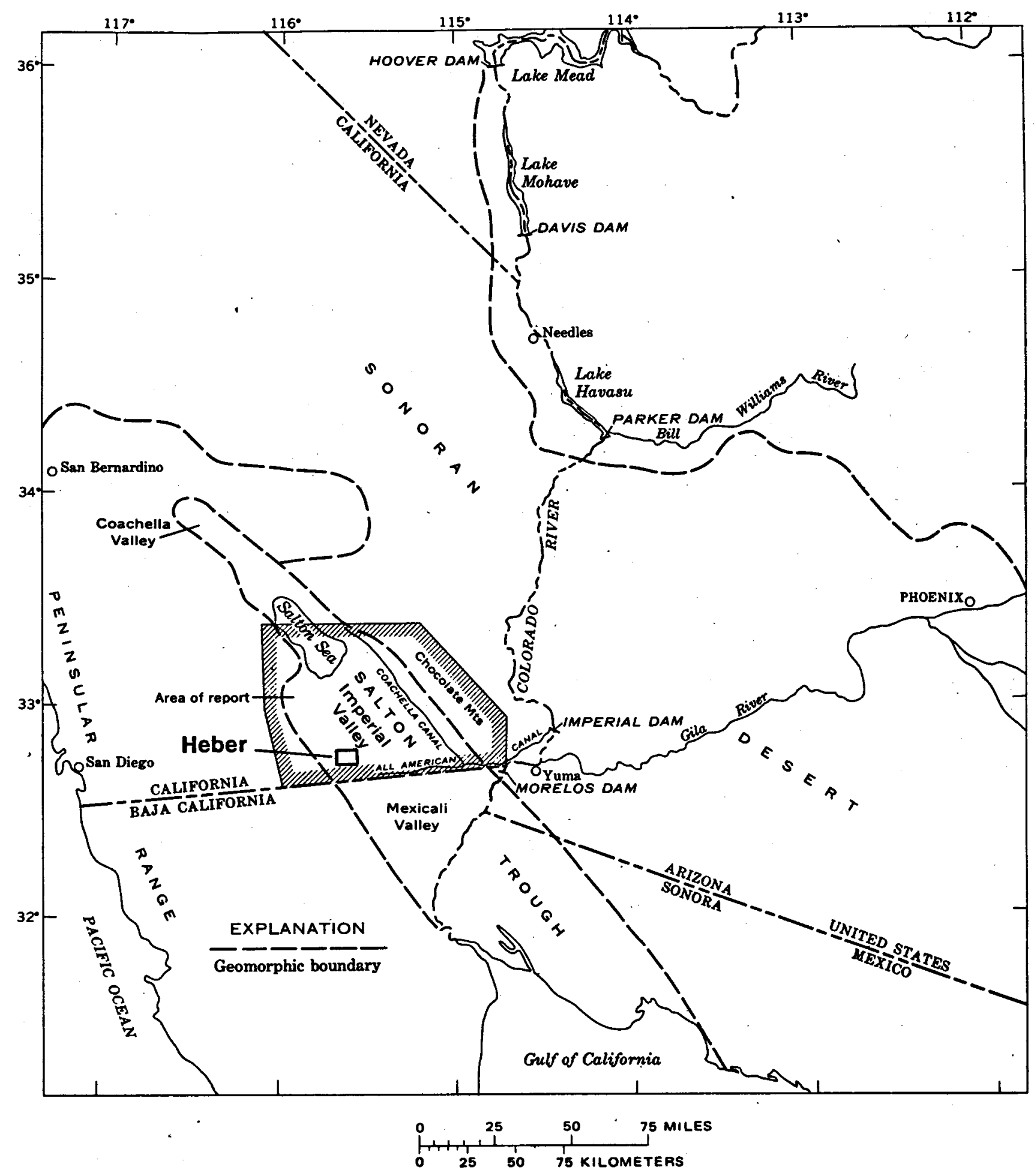

FIGURE NO.I

REGIONAL SETtiNG OF THE IMPERIAL VALLEY(38) 
break in the Colorado River Delta was enlanged by flood waters into a breach $1 \mathrm{~km}(3,281 \mathrm{ft})$ wide and $15 \mathrm{~m}$ (49 ft) deep that required two years of massive cormmity effort to bring under control.

The Heber geothermal area lies just south of El Centro in an extensive array of cultivated fields (Figure No. 2). It is a very flat region with an elevation near sea level and has no rock outcroppings.

The climate of the Imperial valley is characterized by low rainfall, high humidity due to high evapotranspiration, high winds and hot summers. Maximum temperatures commonly exceed $46 \mathrm{C}$ (116 F) in July and August. Winter minimus seldom get below o C (32 F). The average annual precipitation is approximately $7.1 \mathrm{~cm}(2.8 \mathrm{in})$, most of which occurs during summer thunderstorms. 


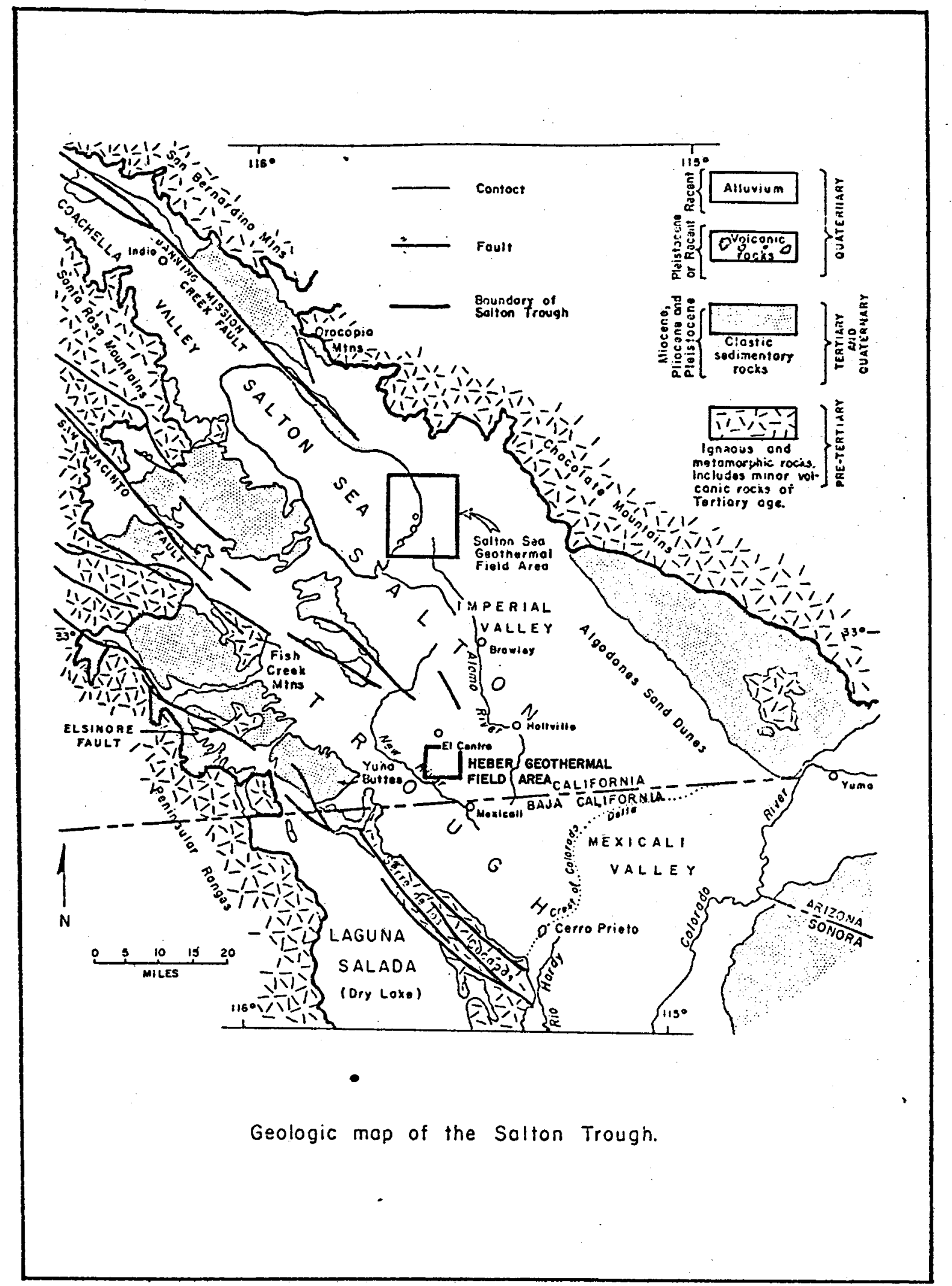

FIGURE NO. 2

GENERAL GEOLOGIC MAP OF THE IMPERIAL VALLE (54) 
GEOLOGY AND GEDPHYSICS

\section{SALTON TROUGH}

The Salton Trough is a complex rift valley of Miocene Age that forms the landward extension of the Gulf of California (17). The Trough is filled to great depths with fluvial, lacustrine and marine deposits of Tertiary and Quatemary age which are primarily derived from colorado River sources and intermittent marine incursions $(13,47,68)$. The Peninsular Ranges to the west are composed chiefly of Cretaceous southern California batholith granites 00 ) while the Chooolate and 00000pia Mountains to the east contain Mesozoic and older granitic and metamorphic rocks (18).

Unlike most rift valleys, the Salton Trough is bounded by active strikeslip faults trending obliquely to its axis, causing the observed rifting usually due to normal fault motion (18). Seismic refraction surveys (5) show that the trough is $6-7 \mathrm{~km}(3.7-4.4 \mathrm{mi})$ deep in the central Imperial Valley (Figure No. 3), but despite this great thickness of low density sediments, the trough has a positive Bouguer gravity (Figures 4 and 5). This implies that the crust beneath the Salton Trough is either thinner or denser than normal continental crust, or both. Gravity modeling by Meidav and Rotstein (43) suggests that the crust in the Imperial Valley may be as thin as $14 \mathrm{~km}(8.7 \mathrm{mi})$. 


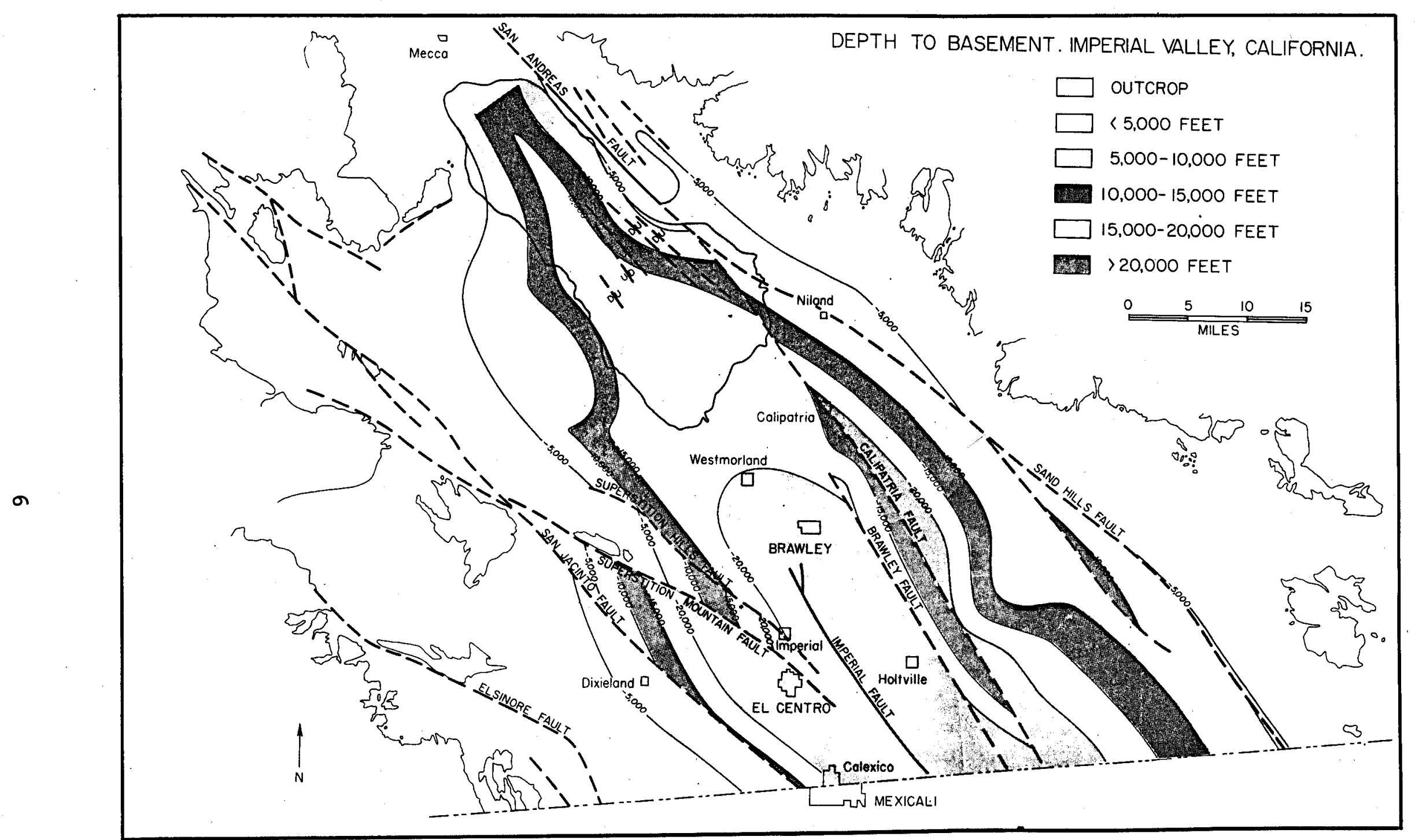

FIGURE NO.3

DEPTH TO BASEMENT ISOPACH MAP (55) 


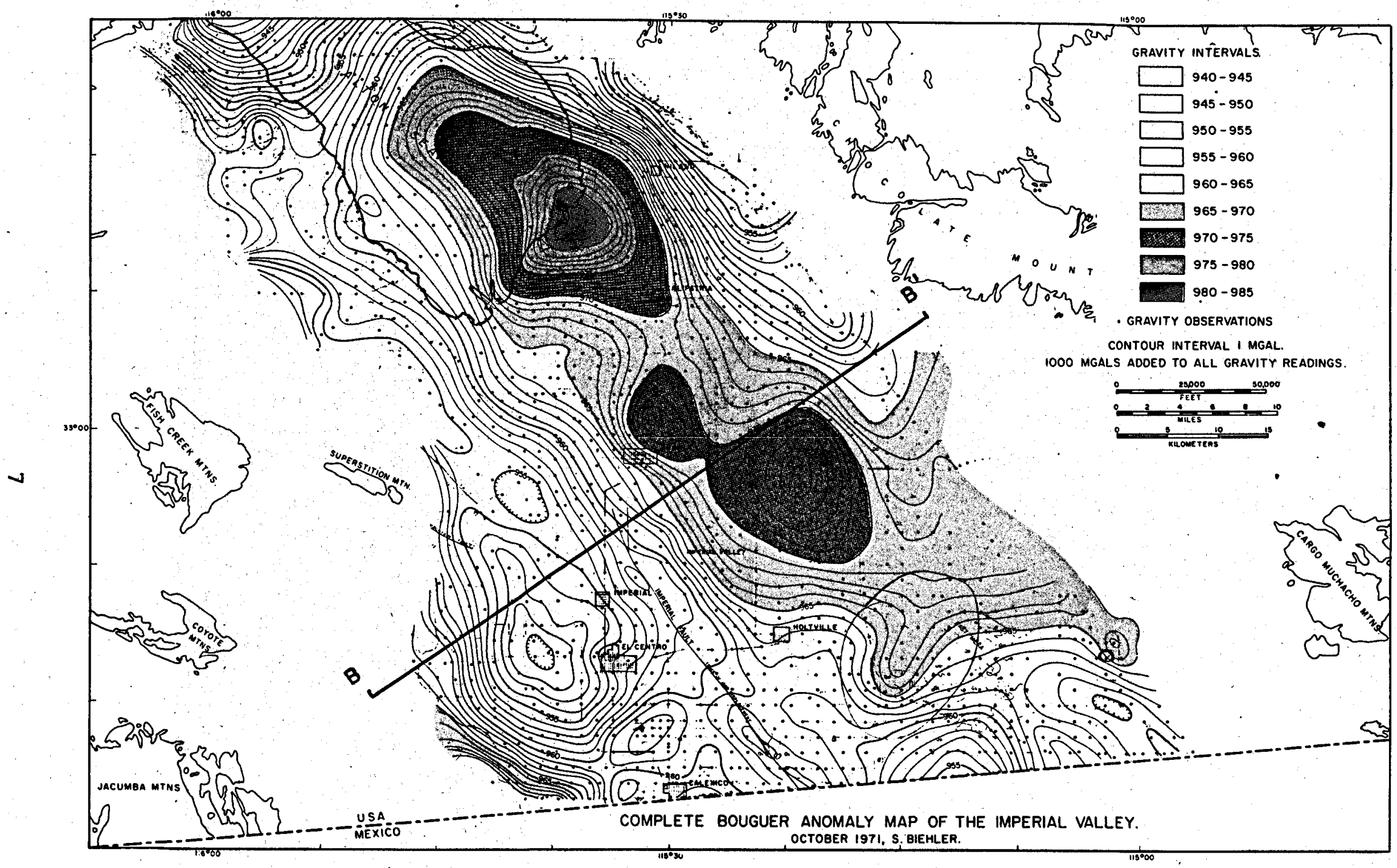

FIGURE NO. 4

BOUGUER GRAVITY FOR THE IMPERIAL VALLEY (6) 

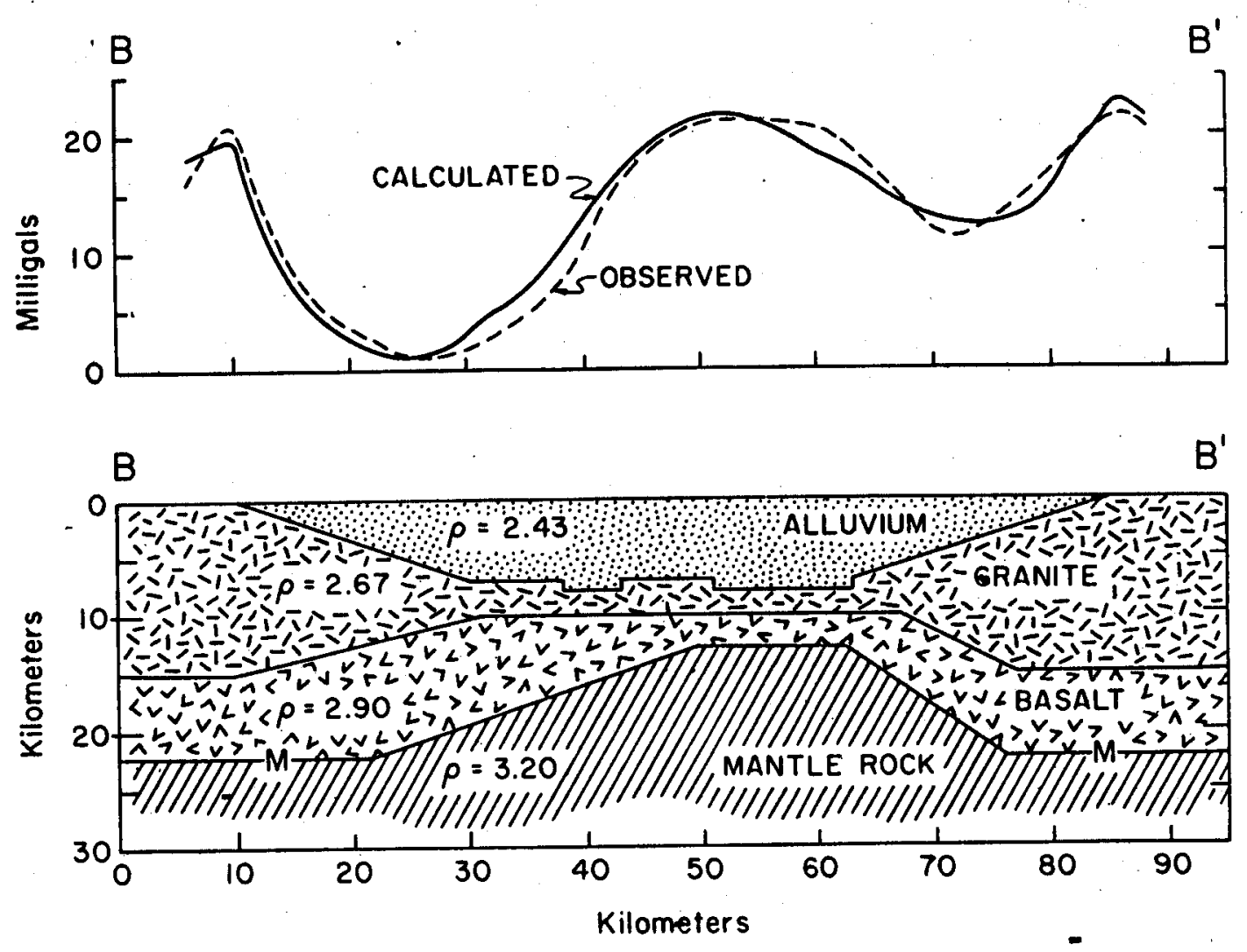

FIGURE NO. 5

CRUSTAL GRAVITY MODELING ACROSS THE IMPERIAL VALLEY (43) 
In a general sense, the existence of the Salton Trough may be explained with plate tectonic models. The observed crustal thinning and basification may be accounted for by the fact that the Salton Trough comprises a part of the active Pacific-North American Plate Boundary, Figure No. 6: (23). The structure of the trough may be largely controlled by the East Pacific rise, an oceanographic spreading center that extends up through the Gulf of California. An evolutionary model for the development of the trough in this framework is given in Figure No. 7 which shows how a thinner, denser crust may be forming under the Salton Trough by processes analogous to coeanic crustal spreading.

\section{IMPERTAL VALIEY}

The Imperial Valley is the most tectonically active part of the Salton Trough. It is an area of high regional heat flow (55), intensive crustal deformation (18), high seismicity and subsidence activity $(26,27)$ and numerous geothermal ancmalies (11).

The Imperial Valley is one of the most seismically active areas in the United States $(2,26,27$. The seismic activity has taken the form of both the classical main shock-aftershock sequences and swarm activity. Numerous active strike-slip faults of the San Andreas system trend into the valley and most of the observed seismic activity occurs along these. The San Andreas fault which bounds the valley to the east (Figure No. 3) and the Elsinore, San Jacinto, and Superstition Hills faults which lie at the western boundaries of the valley are presently less active than the central valley faults $(2,26,27$. These faults, which include the Imperial 


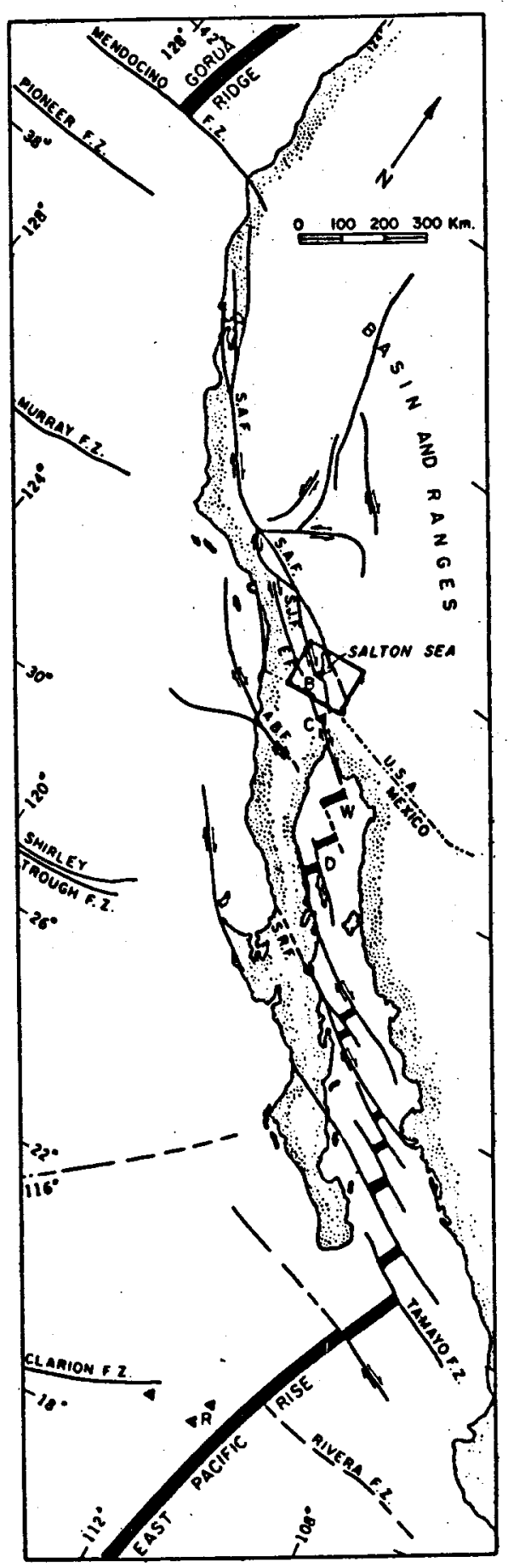

FIGURE NO. 6

TECTONIC SETtING OF THE SALTON TROUGH (23) 


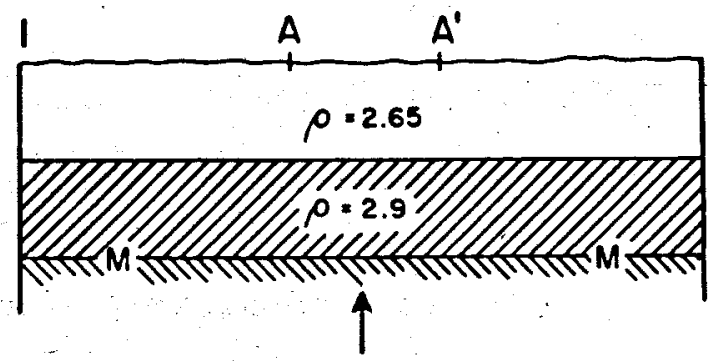

HEATING
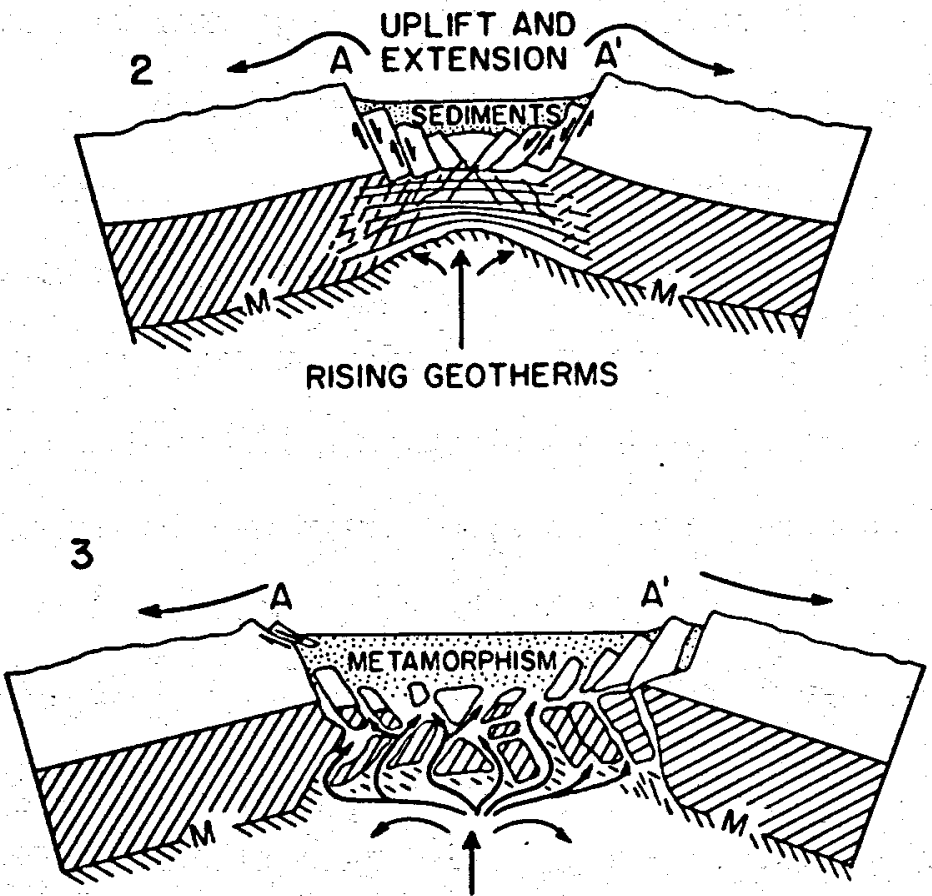

BASALT MAGMA RISING

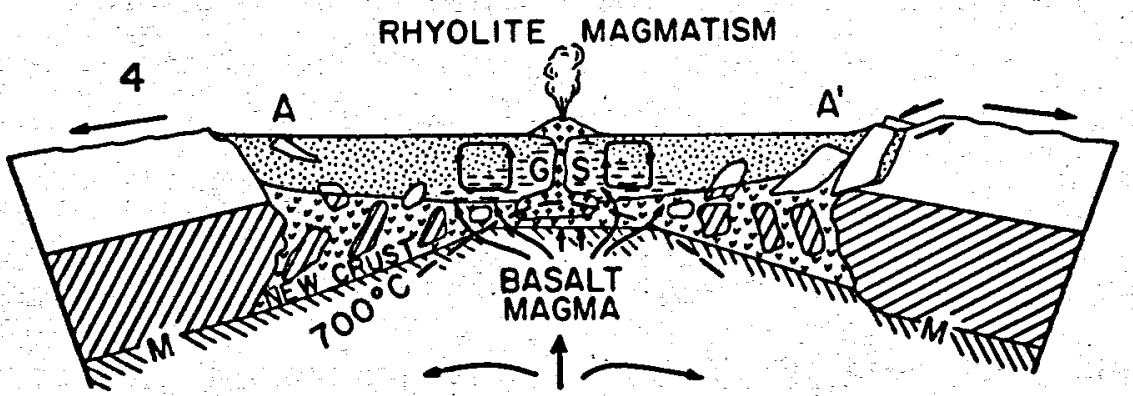

FIGURE NO. 7 
Fault and Brawley Fault, are the sites for much of the observed historical seismic activity (2). Seismicity will be discussed further below.

Gravity and thermal gradient maps of the valley are given in Figure Nos. 4 and 8. These show a strong correlation between thermal gradient anomalies and positive gravity closures, with each geothermal anomaly having an associated gravity positive. This factor, which has greatly simplified geothermal exploration in the valley, may be demonstrated with a convective mass transfer model in which heated subsurface brines cool and precipitate mineral phases while rising up fault conduits. The result is a large amount of intergranular mineralization and near surface densification of country rock; hence, positive gravity anamalies occur (44). It is worth noting that six of the seven geothermal systems found in the valley have no surface leakage manifestation. These systems are either stratigraphically sealed (by thick impermeable clay beds, for example) or self-sealed by mineral precipitation from circulating brines (4). The only exception to this is the Salton Buttes field which is characterized by recent volcanism and the occurrence of mud pots and hot springs.

\section{HEBER ANOMALY}

The Heber Anomaly is located in the south-central part of the Imperial Valley (Figure No. 2). Sediments are dominantly Quaternary deltaic sands and shales derived from Colorado River sources (47). Boreholes show that the deltaic sediments persist to a depth of at least $2.5 \mathrm{~km}(8,203 \mathrm{ft})$ (53), although a $25 \mathrm{~m}$ (82 ft ) thick gabbroic sill was encountered in one of the Chevron Oil Company wells. Depth to basement at Heber, as 


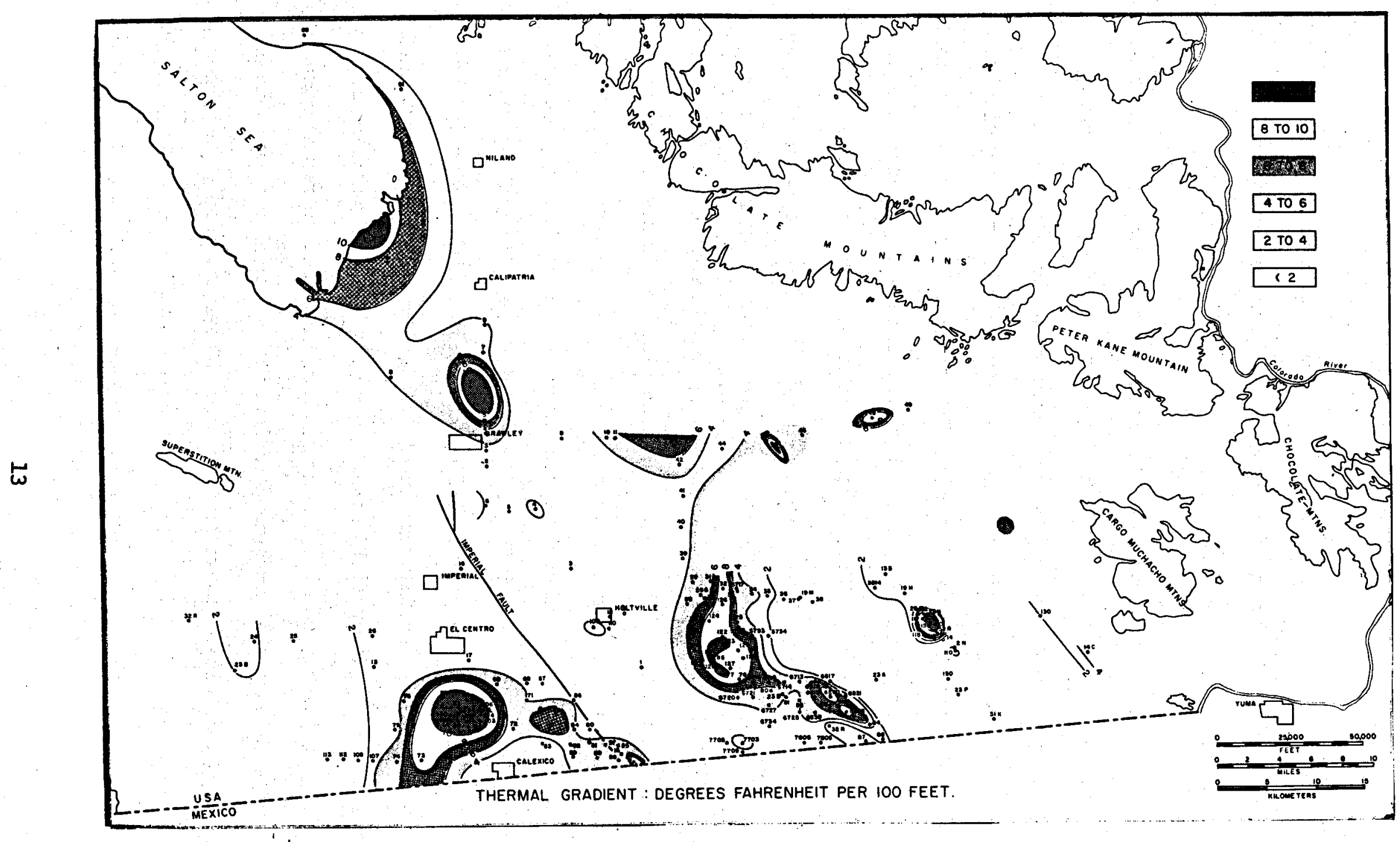

FIGURE NO. 8

THERMAL GRADIENT MAP OF THE IMPERIAL VALLEY (II) 
estimated from seismic surveys (5) is $7 \mathrm{~km} \quad(22,967 \mathrm{ft})$, which is equal to the greatest basement depth thus far enoountered in the valley (Figure No. 3).

Based on deep and shallow borehole data, Rex (55) estimated that the Heber heat flow ancmaly occupies about $35 \mathrm{sq} \mathrm{km}$ (13.5 sq mi ) (Figure No. 8). Numerous geophysical surveys were conducted in the Heber area $(35,42)$, and it was found that the area has gravity and electrical resistivity anomalies associated with the heat flow high. Biehler (6) discovered a 2 mgal gravity positive over Heber of approximately the same shape and size as the heat flow high (Figure No. 4). This gravity contrasts with much larger positives found over the Salton Buttes, North Brawley and East Mesa geothermal fields. Biehler (6) postulated that the lower gravity pointed to the possible existence of a pure steam phase at the Heber field, but to date, drilling has not confirmed his assertion. An analysis of a detailed gravity survey of the Heber area by the Chevron Oil Company indicates that the relative gravity high is surrounded by a moderate gravity low. This may indicate a selective leaching and deposition process, whereby minerals are dissolved from the rocks on the periphery and deposited in the central portion of the field. Meidav and Furgerson (42) showed that the Heber field has an associated low resistivity anomaly (Figure No. 9) although it was noted that the observed resistivity contrast is small because the background resistivities are also very low (less than 2 ohm-meters). These low background resistivities were probably caused by high water salinities due to incomplete mixing and sluggish transport of regional ground water. Meidav and Furgerson (42) also 


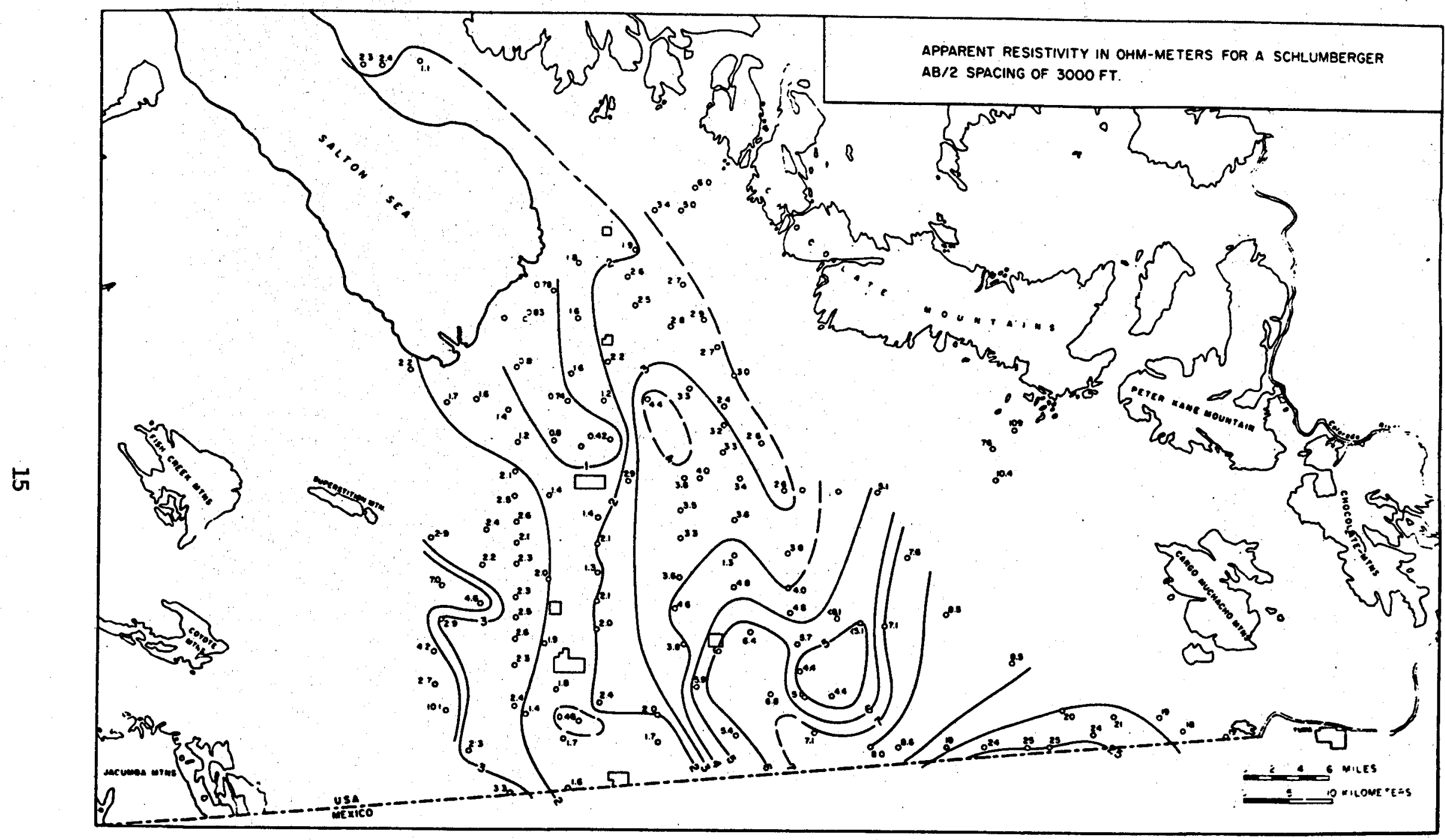

FIGURE NO. 9

ELECTRICAL RESISTIVITY MAP FOR THE VALLEY (42) 
showed that the Imperial Fault serves as an aquitard in the Heber area which separates brackish central valley waters from fresher waters to the east (Figure No. 10). This explains some of the incamplete ground water mixing. 


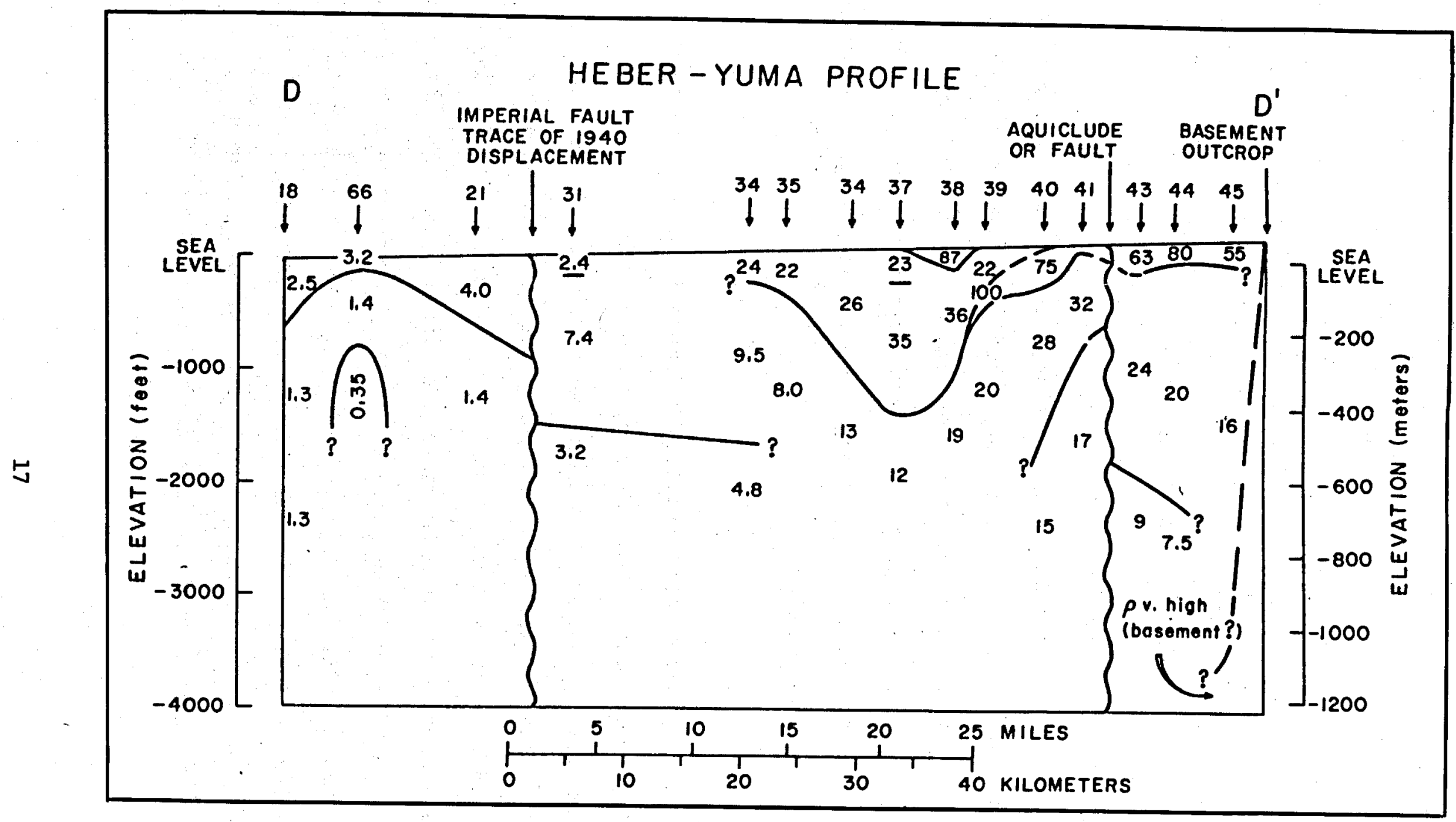

FIGURE NO. 10

EAST-WEST RESISTIVITY CROSS SECTION FROM HEBER TO YUMA(42) 


\section{HYDROLOGY}

\section{INIRODUCIION}

The hydrologic and chemical characteristics of the Imperial Valley waters are highly dependent on sedimentary stratigraphy and the location of prominent faults. Hence, the local geology plays an important role in determining ground water quality and distribution in the valley. Hydrothermal processes may also play an important role in altering water quality and flow characteristics.

\section{HYDROLOGY}

The areal and vertical distribution of sediments in the valley strongly depend on contributions fram the colorado River, which has been the dominant source of valley sediments since the Miocene (47). In general, the grain size of valley sediments is inversely proportional to the distance from the present day Colorado River Delta (45) so that sediments of the southern and eastern Imperial Valley are much coarser than northern and central valley deposits. This relationship generally holds to a depth of at least $2 \mathrm{~km}(6,562 \mathrm{ft})(53)$ and holds best for central and eastern valley deposits. West valley deposits are less affected by contributions fram the Colorado River than fram local sources. Other processes tend to concentrate coarse deposits (sands) on the flanks and fine deposits (clays) in the central valley: these are northwest prevailing winds which 
concentrate sands in south and easterly dune belts, and the several postMiocene lakes which concentrate clays in the central Imperial Valley. The net effects of these sedimentary processes are that they tend to form natural stratigraphic cap rocks for central valley geothermal systems, separate shallow and deep ground water systems and make central valley waters saltier and more stagnant than eastem or western waters.

Meidav and Furgerson (42) have shown that many of the San Andreas system faults act as aquitards for marginal valley waters. They postulate that high salinity gradients existing across northwest-trending faults further increase salinities of central valley ground waters by forming barriers to fluid mixing. It was noted, for instance, that artesian waters exist only east of the Alamo River, suggesting that this river marks one of the proposed aquitards. Meidav and Furgerson (42) have also observed a southeastnorthwest salinity gradient. This could be accounted for by assuming a single recharge source at the Colorado River which implies that waters northward and westward are older, and more saline by prolonged contact with reservoir rocks.

SOURCES OF WATER AND HYDROLOGIC CHARACIERTSTICS

The Colorado River supplies 80 percent of Imperial valley ground water through direct comminication, canal leakage and irrigation discharge. The remaining water is derived from precipitation and runoff from local watershed areas. The total volume of water in storage has been estimated between 1.4 and 3.7 trillion cubic meters ( 1.1 and 3 billion acre-feet) $(16,55)$ (The figure variance occurs because the former estimate was made 
from porosity calculations of sediments shallower than $2,438 \mathrm{~m} \quad(8,000 \mathrm{ft})$ and classification of "usable" water as that with less than 35,000 ppm dissolved solids. Some of the deep Imperial Valley water, particularly in the Salton Buttes area, exceeds this figure). Total recoverable water is estimated to be about 20 percent of the water in storage (16); annual recharge is about 493 millian cubic meters $(400,000$ acre-feet).

The regional water flow pattern is complicated but in general, water flows northwand and westward from the prime sources near the Colorado River Delta. Flow pattern complications arise from natural (fault and stratigraphic) aquitards which channel water flow and from hydrothermal systems whose local convective patterns tend to cause regional waters to flow inward to the anomaly. Stratigraphic separations of deep and shallow waters also tend to complicate flow patterns especially when shallow and deep waters can communicate by fault-induced permeability. In some cases, careful analyses have allowed local flow patterns to be deduced (4), but the general picture still largely remains unclear.

The flow rate of Imperial Valley wells is variable and depends on the location and depth of the well. Many shallow wells at eastern and western valley margins have flowed greater than $0.063 \mathrm{cu} \mathrm{m} / \mathrm{sec}(1,000 \mathrm{gpm})$ whereas central valley shallow wells have produced only a fraction of this. This is partly why the extensive irrigation system was needed in the Imperial Valley. Deep wells in the central valley, however, flow as well or better than deep wells at the valley margins. Adequate sampling of these wells is not yet available, however, to clearly establish a pattern. 
CHEMICAL QUALITY OF WATERS IN THE IMPERIAL VALTEY

Imperial Valley waters may be divided chemically into several different categories, of which the principal ones are:

- Basin-edge waters which strongly resemble colorado River source waters (See Table Nos. 1 and 2).

- Shallow Central Valley waters which are somewhat more saline and richer in carbonate (Table No. 3).

- Deep valley waters which tend to be more saline but resemble basin-edge waters in ionic ratio.

- Hydrothermal water which tends to have increased silica, pH, metal salts, and salinity (Table No. 4).

- Hypersaline geothermal brines which contain unusually high salinities and are confined to the Salton Buttes (Table No. 5).

The variety of waters demonstrates the complexity of the hydrologic system in the Valley. The quality of the water is dependent upon geologic and source factors. Table Nos. 1-5 show, for example, that dissolved constituents range fram 790 to 259,000 ppm.

Recent studiess (38) show that the shallow ground water in the Valley has changed in quality due to source water changes, extensive irrigation and use of fertilizers. Consequently, the ground water has become more saline. This trend is expected to continue.

The Valley's geothermal brines do not differ greatly from deep waters in the area except for the addition of metal salts and the dissolution of carbonates. Hence, some geothermal wells evolve $\mathrm{CO}_{2}$ gas. The deep brine in the Salton Buttes area is very unusual (See Table No. 5). This brine contains up to 300,000 ppm dissolved solids which, in addition to major 
TABLE NO. 1

AVERAGE COTORADO RIVER WATER AT LAKE HAVASU (HOLBURT, 1970)

\begin{tabular}{|l|r|}
\hline Constituent & ppm \\
\hline $\mathrm{Na}$ & 108 \\
$\mathrm{Ca}$ & 85 \\
$\mathrm{Mg}$ & 31 \\
$\mathrm{HCO}_{3}$ & 145 \\
$\mathrm{SO}_{4}$ & 307 \\
$\mathrm{Cl}$ & 98 \\
Others & 17 \\
\hline & \\
TDS & 791 \\
\hline
\end{tabular}

TABLE NO. 3

AVERAGE SHALION IMPERIAL VALIEY WATER (38)

\begin{tabular}{|l|r|}
\hline Constituent & ppm \\
\hline $\mathrm{Na}$ & 932 \\
$\mathrm{Ca}$ & 23 \\
$\mathrm{Mg}$ & 12 \\
$\mathrm{HOO}_{3}$ & 204 \\
$\mathrm{SO}_{4}$ & 88 \\
$\mathrm{Cl}$ & 1330 \\
Others & 115 \\
\hline & \\
TDS & 2510 \\
\hline
\end{tabular}

TABLE NO. 2

BASIN EDGE WATERS

(EAST MESA) (38)

\begin{tabular}{|l|r|}
\hline Constituent & ppm \\
\hline $\mathrm{Na}$ & 144 \\
$\mathrm{Ca}$ & 97 \\
$\mathrm{Mg}$ & 30 \\
$\mathrm{HCO}_{3}$ & 163 \\
$\mathrm{SO}_{4}$ & 362 \\
$\mathrm{Cl}^{\circ}$ & 119 \\
Others & 35 \\
\hline & \\
TDS & 950 \\
\hline
\end{tabular}

TABLE NO. 4

TYPICAL GEOTHERMAL BRTNE MESA 6-1 (65)

\begin{tabular}{|l|c|}
\hline Constituent & $\begin{array}{c}\text { ppm } \\
\text { (except pH) }\end{array}$ \\
\hline $\mathrm{pH}$ & 6.1 \\
& \\
$\mathrm{SiO}_{2}$ & 220 \\
$\mathrm{Na}$ & 5129 \\
$\mathrm{Mg}$ & 22 \\
$\mathrm{HCO}_{3}$ & 304 \\
$\mathrm{SO}_{4}$ & 20 \\
$\mathrm{Cl}$ & 9014 \\
Others & 1082 \\
\hline & \\
TDS & 15791 \\
\hline
\end{tabular}


TABIE NO. 5

SALTON SEA BRTNES

HYPERSAITIE BRTNE AT THE SHELL I.I.D. NO. 2 WELC (24)

\begin{tabular}{|l|r|}
\hline Constituent & \multicolumn{1}{|c|}{ ppm } \\
\hline $\mathrm{Na}$ & 53,000 \\
$\mathrm{~K}$ & 16,500 \\
$\mathrm{Ii}$ & 210 \\
$\mathrm{Ba}$ & 250 \\
$\mathrm{Ca}$ & 27,800 \\
$\mathrm{Sr}$ & 440 \\
$\mathrm{Mg}$ & 10 \\
$\mathrm{Fe}$ & 2,000 \\
$\mathrm{Mn}$ & 1,370 \\
$\mathrm{~Pb}$ & 80 \\
$\mathrm{Zn}$ & 500 \\
$\mathrm{Cu}$ & 3 \\
$\mathrm{Cl}$ & 155,000 \\
$\mathrm{CO}$ & 500 \\
$\mathrm{~S}$ & 30 \\
$\mathrm{~B}$ & 390 \\
$\mathrm{SiO}$ & \\
$\mathrm{TD}$ & 400 \\
$\mathrm{TD}$ & \\
\hline
\end{tabular}


amounts of sodium, calcium, potassium and chloride ions, contains significant amounts of corrosive $\mathrm{HCl}$ and $\mathrm{H}_{2} \mathrm{SO}_{4}$, as well as traces of lithium, fluoride, strontium and others. The corrosive and scaling properties of the Salton Buttes brine have been the major deterrent in developing that geothermal field.

GEOTHERMAL WATERS AT HEBER

The shallow ground water at Heber is characteristic of Central Imperial Valley waters (Table No. 3), but there is evidently very little cormuication with deeper hydrothermal waters since the character of this water is vastly different. This is probably due to the presence of a clay and silt cap rock above the geothermal reservoir that is several hundred feet thick.

Geothermal waters at Heber are produced fram a depth of 600 to 1,900 m $(1,968$ to $6,232 \mathrm{ft})$; Table No. 6 presents chemical analyses data from five geothermal wells. Sodium chloride is the predominant dissolved constituent of the geothermal water and the average $\mathrm{pH}$ indicates a slightly acidic to neutral condition. Moderate concentrations of silica suggest that silica scaling at the well bore or surface pipes will not be $\dot{a}$ problem at Heber and trial production and injection operations at Heber have not shown any corrosion or scaling problems to date. Only traces of hydrogen sulfide have been reported from wells and the amount of noncondensable gases in Heber geothermal water is minimal.

The geothermal water from Heber shows similarities to that from the Cerro Prieto, Mexico geothermal reservoir (Table No. 7), particularly in regard to total dissolved solids concentrations. This suggests a conmon original 
TABIE NO. 6

CHEMICAL QUALITY OF WATER, HEBER GEOTHERMAL RESERWOIR IMPERIAL VALIEY, CALIFORNIA

\begin{tabular}{|c|c|c|c|c|c|}
\hline Parameter* & Nowlin \#1 & Holtz \#1 & Holtz \#2 & C.B. Jackson \#1 & J.D. Jackson \#1 \\
\hline $\begin{array}{l}\text { Total } \\
\text { Dissolved } \\
\text { Solids } \\
\text { (IDS) }\end{array}$ & 14,100 & 13,168 & 16,330 & 15,430 & 15,275 \\
\hline $\begin{array}{l}\mathrm{SiO}_{2} \\
\mathrm{Ii} \\
\mathrm{Na} \\
\mathrm{K} \\
\mathrm{Ca} \\
\mathrm{Mg} \\
\mathrm{Cl} \\
\mathrm{SO}_{4} \\
\mathrm{O}_{3} \\
\mathrm{HOO}_{3} \\
\mathrm{~F} \\
\mathrm{~B} \\
\mathrm{Fe} \\
\mathrm{Mn} \\
\mathrm{Pb} \\
\mathrm{Zn} \\
\mathrm{Cu} \\
\mathrm{Ba} \\
\mathrm{Sr} \\
\mathrm{Al} \\
\mathrm{Ag} \\
\mathrm{II} \\
\mathrm{pH}\end{array}$ & $\begin{array}{r}120 \\
6.6 \\
3,600 \\
360 \\
880 \\
2.4 \\
9,000 \\
100 \\
4 \\
20 \\
1.6 \\
4.8 \\
0.9 \\
\text { NA } \\
0.1 \\
0.68 \\
0.2 \\
\text { NA } \\
\text { NA } \\
0.04 \\
\text { NA } \\
4 \\
7.1\end{array}$ & $\begin{array}{r}268 \\
4 \\
5,500 \\
220 \\
1,062 \\
5.6 \\
7,420 \\
100 \\
\text { NA } \\
\text { NA } \\
1.7 \\
4.1 \\
15 \\
0.9 \\
1.6 \\
0.3 \\
0.5 \\
6 \\
37 \\
15 \\
\text { NA } \\
\text { NA } \\
\text { NA }\end{array}$ & $\begin{array}{r}187 \\
4.1 \\
4,720 \\
231 \\
1,062 \\
23 \\
8,242 \\
148 \\
\mathrm{NA} \\
\mathrm{NA} \\
1.5 \\
8 \\
5 \\
0.9 \\
0.6 \\
0.1 \\
0.4 \\
3 \\
42 \\
12 \\
\mathrm{NA} \\
\mathrm{NA} \\
7.4\end{array}$ & $\begin{array}{c}267 \\
2.8 \\
4,688 \\
181 \\
891 \\
4.7 \\
8,320 \\
152 \\
\mathrm{NA} \\
\mathrm{NA} \\
0.9 \\
4.8 \\
20 \\
1.3 \\
0.6 \\
0.4 \\
0.4 \\
3 \\
32 \\
0.5 \\
\mathrm{NA} \\
\mathrm{NA} \\
5.8\end{array}$ & $\begin{array}{r}268 \\
3.4 \\
4,563 \\
197 \\
781 \\
3.8 \\
8,076 \\
150 \\
\mathrm{NA} \\
\mathrm{NA} \\
0.6 \\
5.2 \\
10 \\
1.9 \\
0.9 \\
0.5 \\
0.4 \\
3 \\
36 \\
18 \\
\mathrm{NA} \\
\mathrm{NA} \\
6.5\end{array}$ \\
\hline
\end{tabular}

*Except pH, all parameters are in parts per million. 
TABIE NO. 7

ANALYSIS OF GEOTHERRAL WATER FROM

CERRO PRIETO, B.C. , MEXICO

\begin{tabular}{|c|c|c|c|c|c|c|}
\hline \multirow[b]{2}{*}{ Constituent (ppm)* } & \multicolumn{6}{|c|}{ Well Number } \\
\hline & $1-A$ & $\mathrm{M}-3$ & $M-5$ & M-6 & $M-7$ & M-8 \\
\hline $\mathrm{Na}$ & 4,450 & 5,310 & 5,820 & 5,000 & 5,250 & 6,100 \\
\hline K & 600 & 1,100 & 1,570 & 504 & 910 & 1,860 \\
\hline Li & 12 & 17 & 19 & 11 & 13 & $\therefore 17$ \\
\hline $\mathrm{Ca}$ & 210 & 310 & 280 & 388 & 230 & 390 \\
\hline Mg & 30 & 11 & 8 & 33 & 18 & 6 \\
\hline $\mathrm{Cl}$ & 7,420 & 9,680 & 10,420 & 9,000 & 9,310 & 11,750 \\
\hline $\mathrm{Br}$ & 5.2 & 10.0 & 14.1 & 12.6 & 9.2 & 14.3 \\
\hline$I$ & 1.0 & 2.8 & 3.1 & 2.5 & 2.6 & 3.2 \\
\hline $\mathrm{Fe}$ & nd & 0.2 & 0.2 & nd & nd & nd \\
\hline $\mathrm{SO}_{4}$ & 7.0 & 15 & 0.0 & 16.4 & 3.4 & 0.0 \\
\hline $\mathrm{HCO}_{3}$ & 52 & 60 & 73 & 158 & 71 & 890 \\
\hline $\mathrm{H}_{3} \mathrm{BO}_{4}$ & 52 & 55 & 71 & 21 & 32 & 115 \\
\hline $\mathrm{SiO}_{2}$ & 240 & 480 & 740 & 151 & 390 & 770 \\
\hline$\infty_{2}$ & nd & 680 & 1,600 & 420 & 940 & nd \\
\hline $\mathrm{H}_{2} \mathrm{~S}$ & nd & 218 & 700 & 37 & 180 & nd \\
\hline $\begin{array}{l}\text { Total Hardness } \\
\text { (as caCO3) }\end{array}$ & 699 & 820 & 733 & 1,106 & 649 & 1,000 \\
\hline $\begin{array}{l}\text { Total Dissolved } \\
\text { Solids (TDS) }\end{array}$ & 13,082 & 18,041 & 19,018 & 18,412 & 16,240 & 21,915 \\
\hline
\end{tabular}

nd $=$ Not Determined 
source of water, probably the colorado River, for both reservoirs. One significant difference exists between the reported content of noncondensables in Cerro Prieto geothermal fluids and those at Heber. Whereas at cerro Prieto the $\mathrm{CO}_{2}$ content is about $1,000 \mathrm{ppm}$, and the $\mathrm{H}_{2} \mathrm{~S}$ content is about 300 ppm, there are only traces of $\mathrm{CO}_{2}, \mathrm{H}_{2} \mathrm{~S}$ and other noncondensables in the Heber geothermal fluids.

It is estimated that between 50 to 60 producing wells and 20 to 30 injection wells will be required for a $200 \mathrm{MW}$ net electricity plant at Heber. The injection wells will be located on concentric circular arrays with diameters of about $3,020 \mathrm{~m}(9,900 \mathrm{ft})$. The possible changes in ground water flow pattern due to this development may be:

- Changes in ground water quantity and flow direction

- Chemical changes in ground water as a result of possible mixing with reinjection waters

- Diversion of deep water from other areas

- Effect on deep waters of salt water reinjection

Considering the effective hydrologic separation between the geothermal reservoir and the shallow ground water system at Heber, the only likely changes are the diversion of deep water from other areas and the effect on deep waters of salt water reinjection, and the projected extent of such changes is minor. At Cerro Prieto, for example, shallow ground water has hardly been affected by geothermal development except in cases where wastewater was directly injected into the local water system. 


\section{SEISMICITY AND SUBSIDENCE}

\section{SEISMIC AND SUBSIDENCE MONITORING}

Earthquake data in the Imperial Valley have been recorded on a broad scale. since 1927. In 1934, a seismic station in the valley was established as part of the California Institute of Technology's (Cal Tech) permanent southern California seismic net. The plan for recording was to move portable seismic stations to an area after a large magnitude event, such as the Imperial earthquake of 1940, and record the sequence of aftershocks. In 1973, the United States Geological Survey (U.S.G.S.) in cooperation with the California Institute of Technology established a sixteen-station telemetered network in the Imperial Valley (Figure No. 11) to record and interpret earthquakes related to the geothermal phenomenon (27). In the Heber area Chevron Oil Company plans to establish a closely spaced seismic net to gather information on background seismicity and the relationship the proposed geothermal production might have on seismic activity. The above project is scheduled for implementation in 1976 and will run continuously throughout the period of power production (acoording to E. Drobick in a personal communication in March, 1976).

Ground motion data (both horizontal and vertical) have been available in the valley since 1934 when the U.S. Coast and Geodetic Survey established the first triangulation and leveling network there. The network was remeasured in 1941, 1954, 1967 and 1972. In 1970, as part of the Imperial Valley 


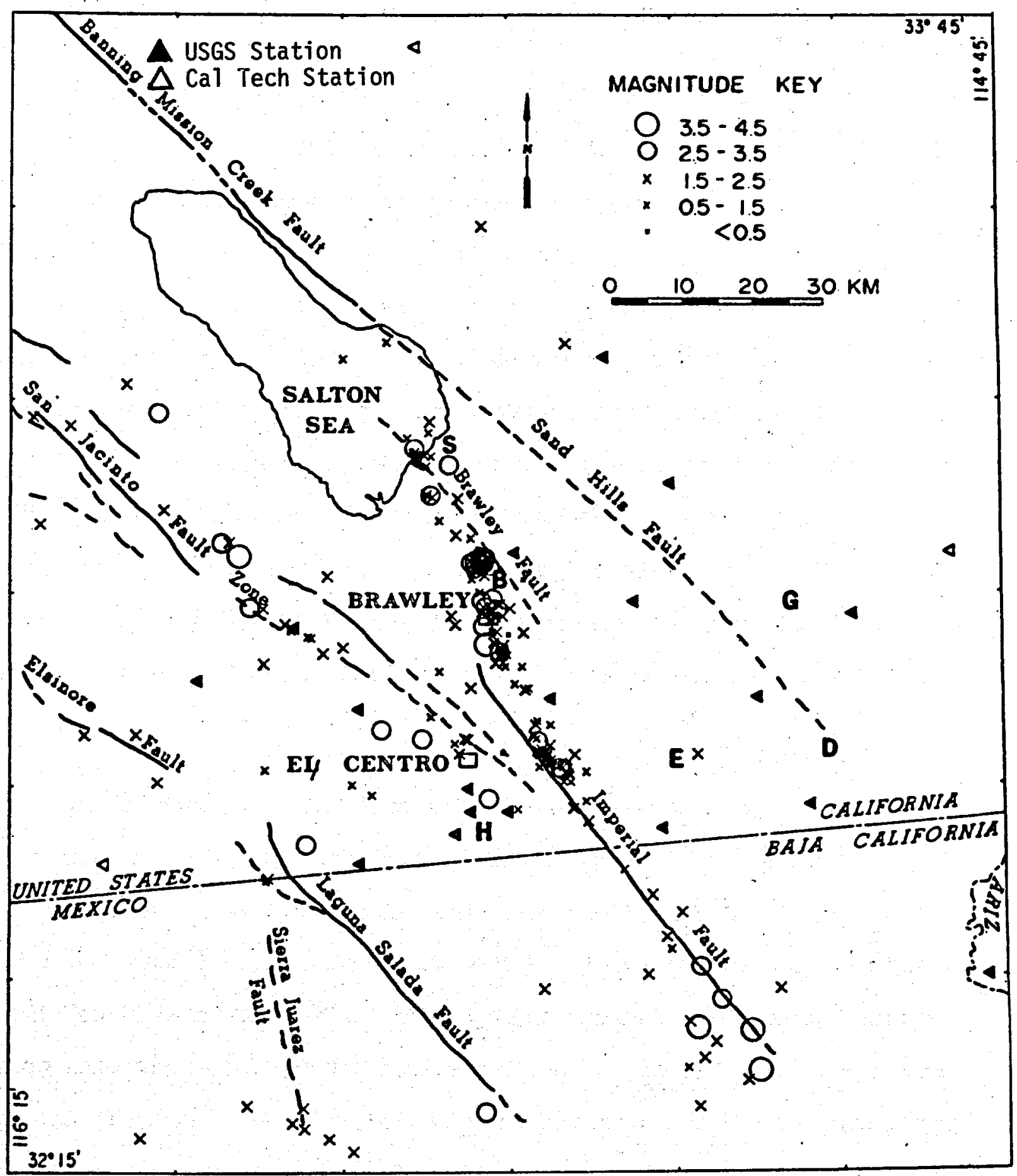

FIGURE NO.11

LOCATION OF EARTHQUAKE EPICENTERS IN THE IMPERIAL VALLEY FOR THE PERIOD JUNE 1,1973 THROUGH MAY 31, 1974 (26) 
Project (55), an array of 141 benchmarks was established in the southern Imperial Valley to monitor fault motion (Figure No. 12). In 1971, the U.S. Coast and Geodetic Survey, in cooperation with the U.S.G.S., undertook an extensive program to monitor ground motion through the Imperial Valley. This program calls for triangulation and leveling surveys throughout the valley every two years and more frequently if geothermal production becomes a reality in the valley (39). In addition, a system of tiltmeters, extensometers and level nets was established at Salton Buttes, East Mesa and Heber to detect any ground motion related to geothermal production (Figure Nos. 13 and 14). Added to the above data was a private leveling survey done by Chevron Oil Company in the Heber area. This 1974-1975 survey measured the relative elevation change in the Heber area over a year's period.

\section{HISTORICAL SEISMICITY}

The Salton Trough in general, and the Imperial Valley in particular, is characterized by a high level of seismic activity and a large amount of strain release. Richter (59) reports that 12 earthquakes of magnitude 6 or greater have occurred in the Salton Trough since 1900 (Figure No. 15) and nine earthquakes greater than magnitude 6.7 have occurred since 1850 (Figure No. 16). Figure No. 17 is an epicentral map for earthquakes greater than magnitude $4.0^{\circ}$ that occurred between 1932 and 1972 in southern California. It is evident that a large concentration of events occurred in the Salton Trough along faults of the San Andreas System. Smaller shocks and earthquake swarms are also very common for faults in the San Andreas System $(25,27)$.

The Imperial Valley fault system, which includes the Banning-Mission Creek, Imperial, Brawley, Elsinore and San Jacinto Faults, among others, is 


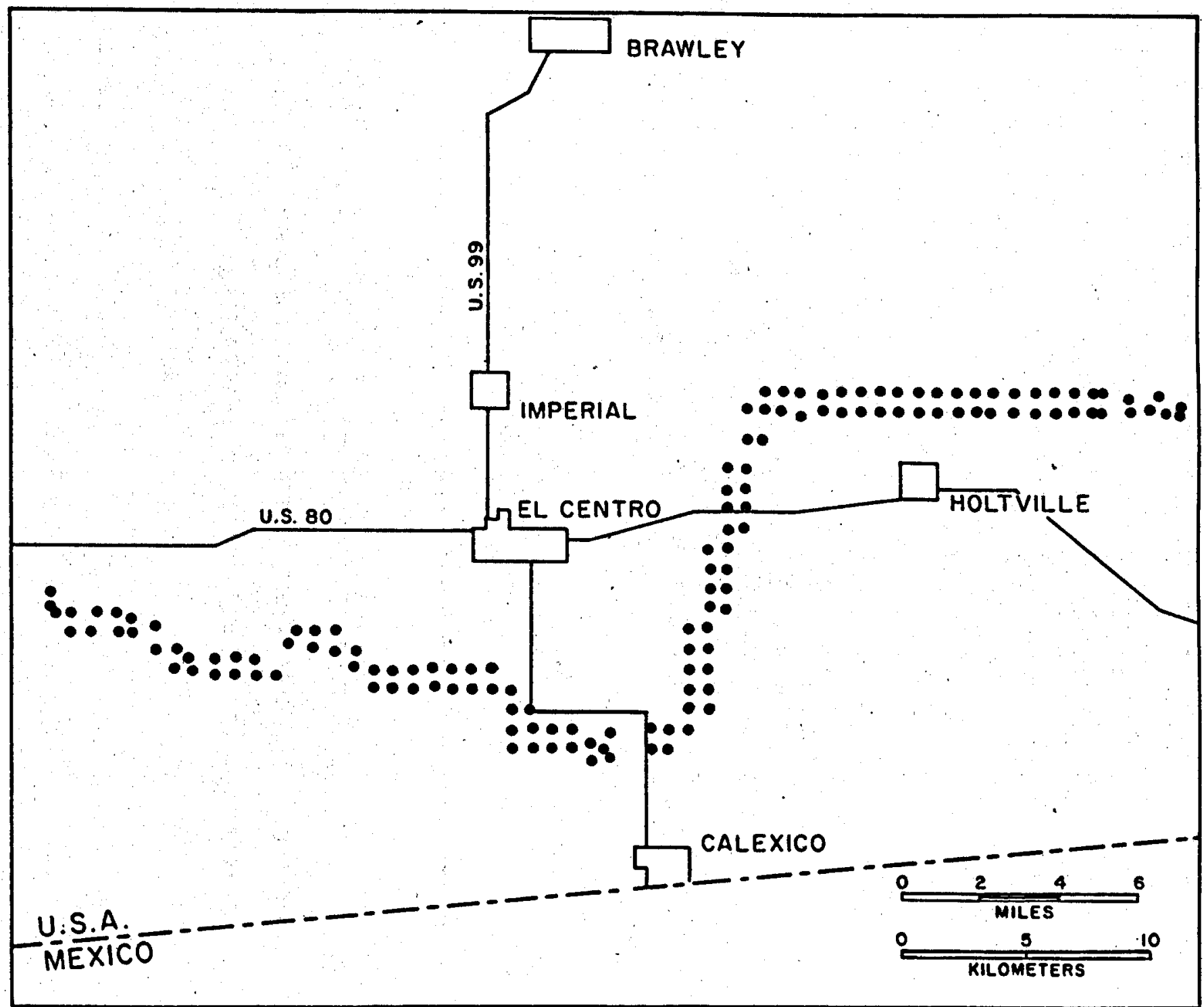

FIGURE NO.12

NETWORK OF BENCHMARKS ESTABLISHED IN 1970 DURING THE U.C.-RIVERSIDE, IMPERIAL VALLEY GEOTHERMAL PROJECT(55) 


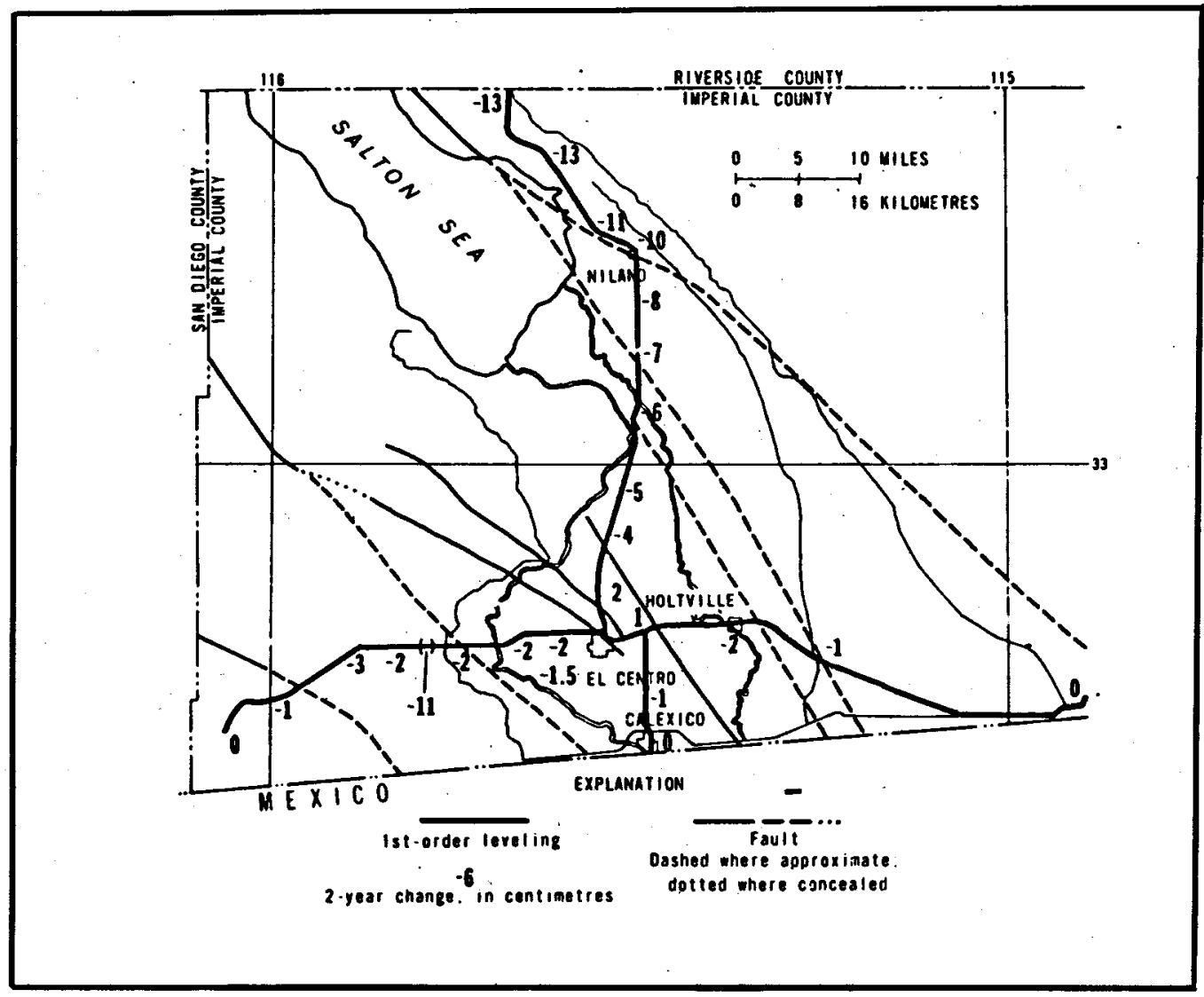

FIGURE NO.13

NETWORK OF FIRST ORDER VERTICAL CONTROL AND

2-YEAR CHANGE IN ELEVATION, 1972-1974 (39) 


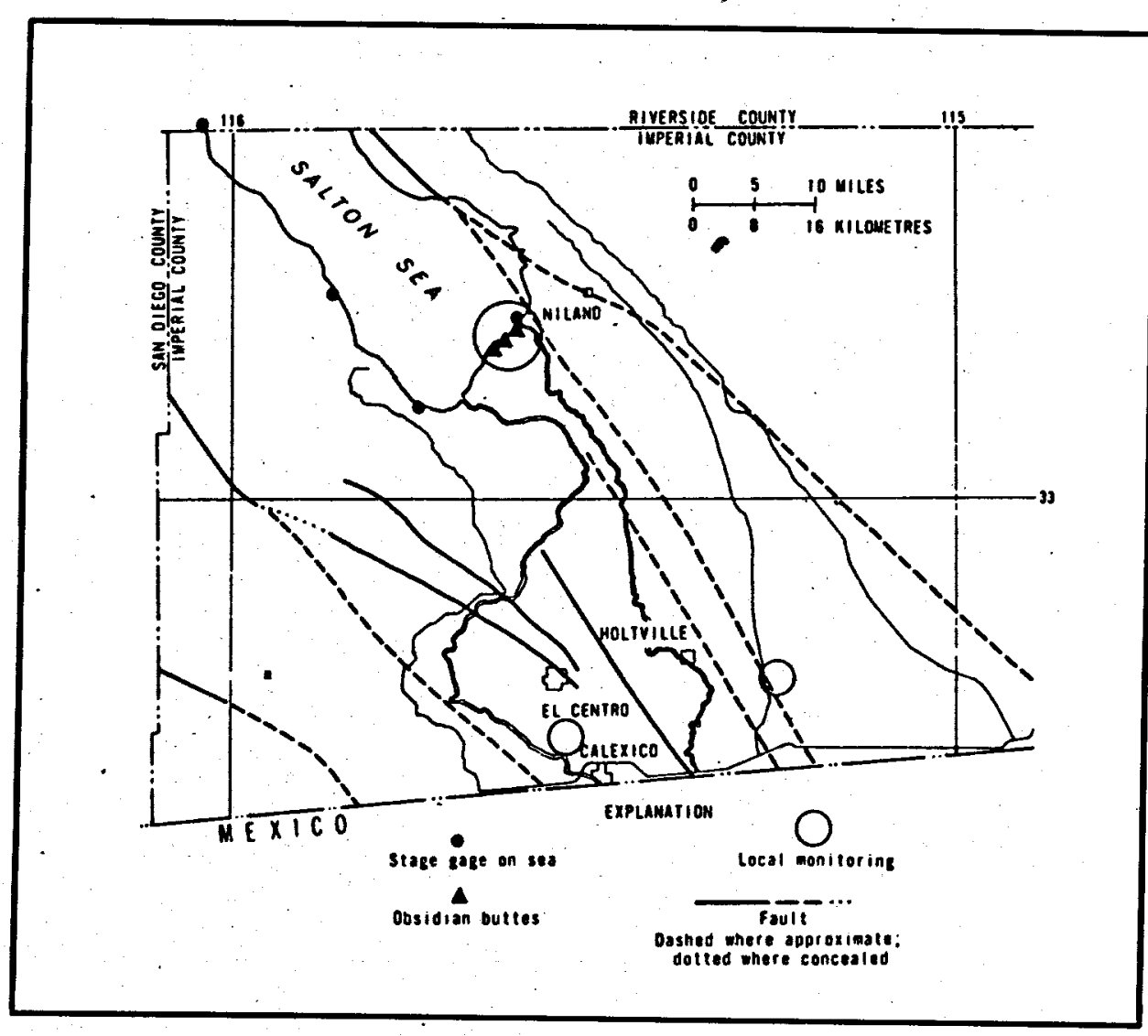

FIGURE NO.14

GEOTHERMAL AREAS OF LOCAL VERTICAL AND HORIZONTAL CONTROL(39) 


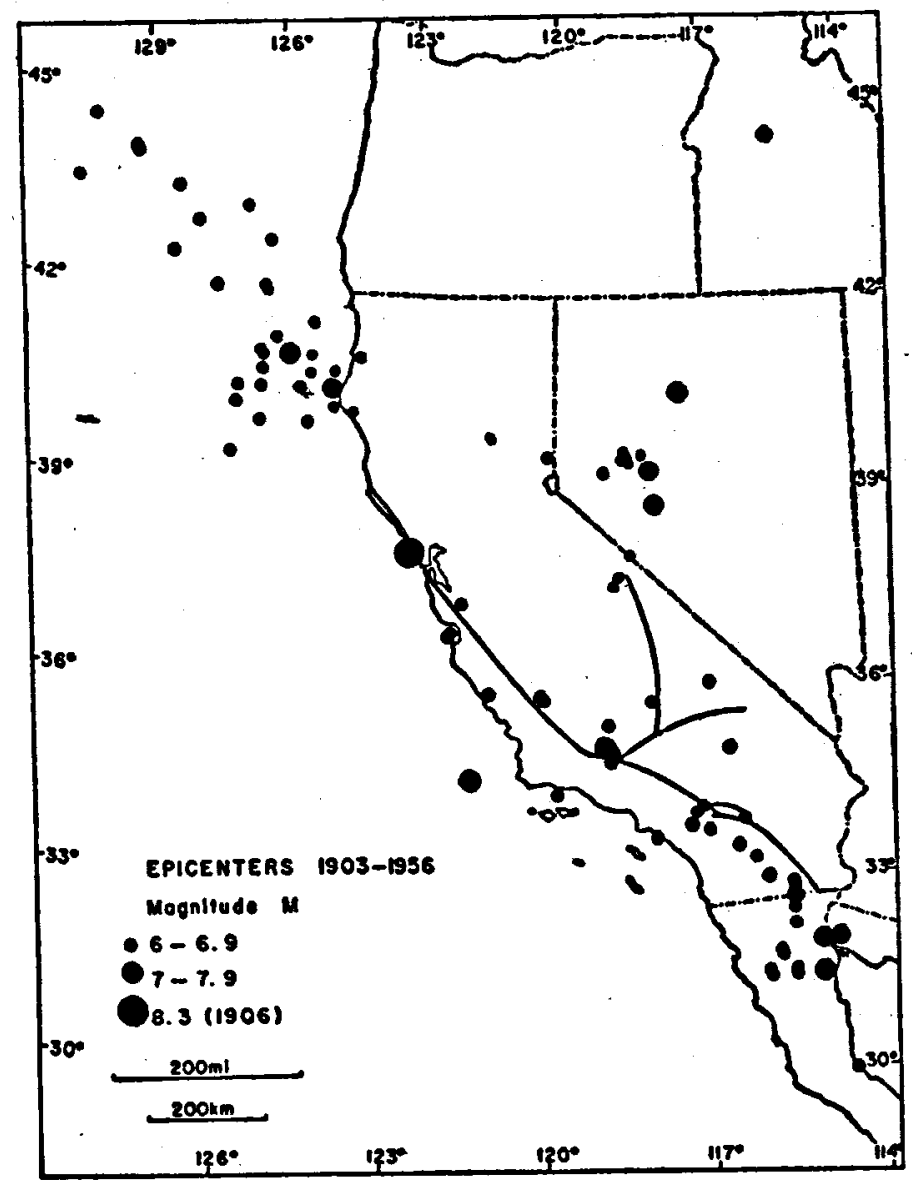

FIGURE NO.15

CALIFORNIA-NEVADA EARTHQUAKES, MAGNITUDE 6

AND OVER, 1903-1956(59) 


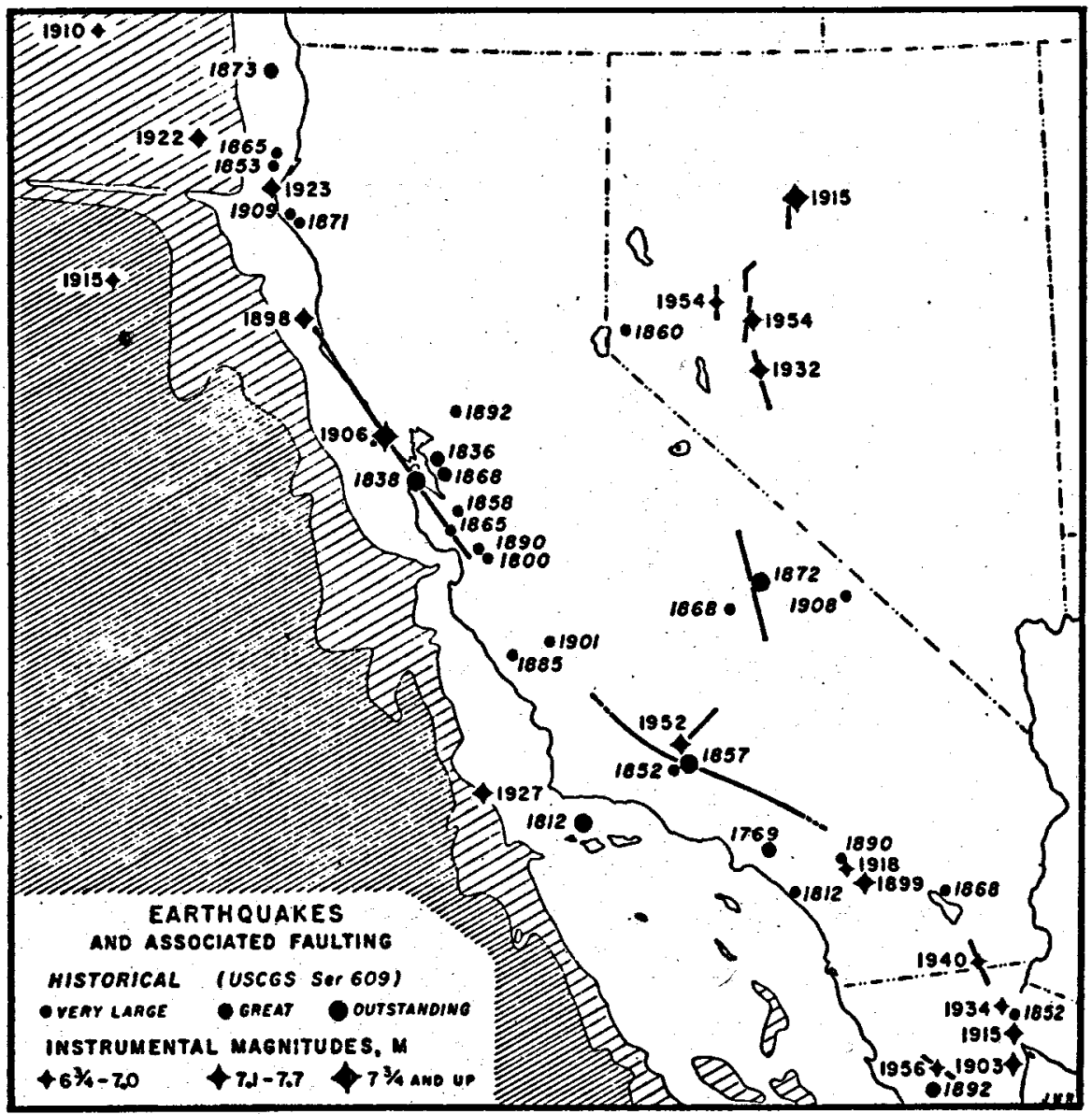

FIGURE NO.16

LARGE EARTHQUAKES IN CALIFORNIA REGION (59) 


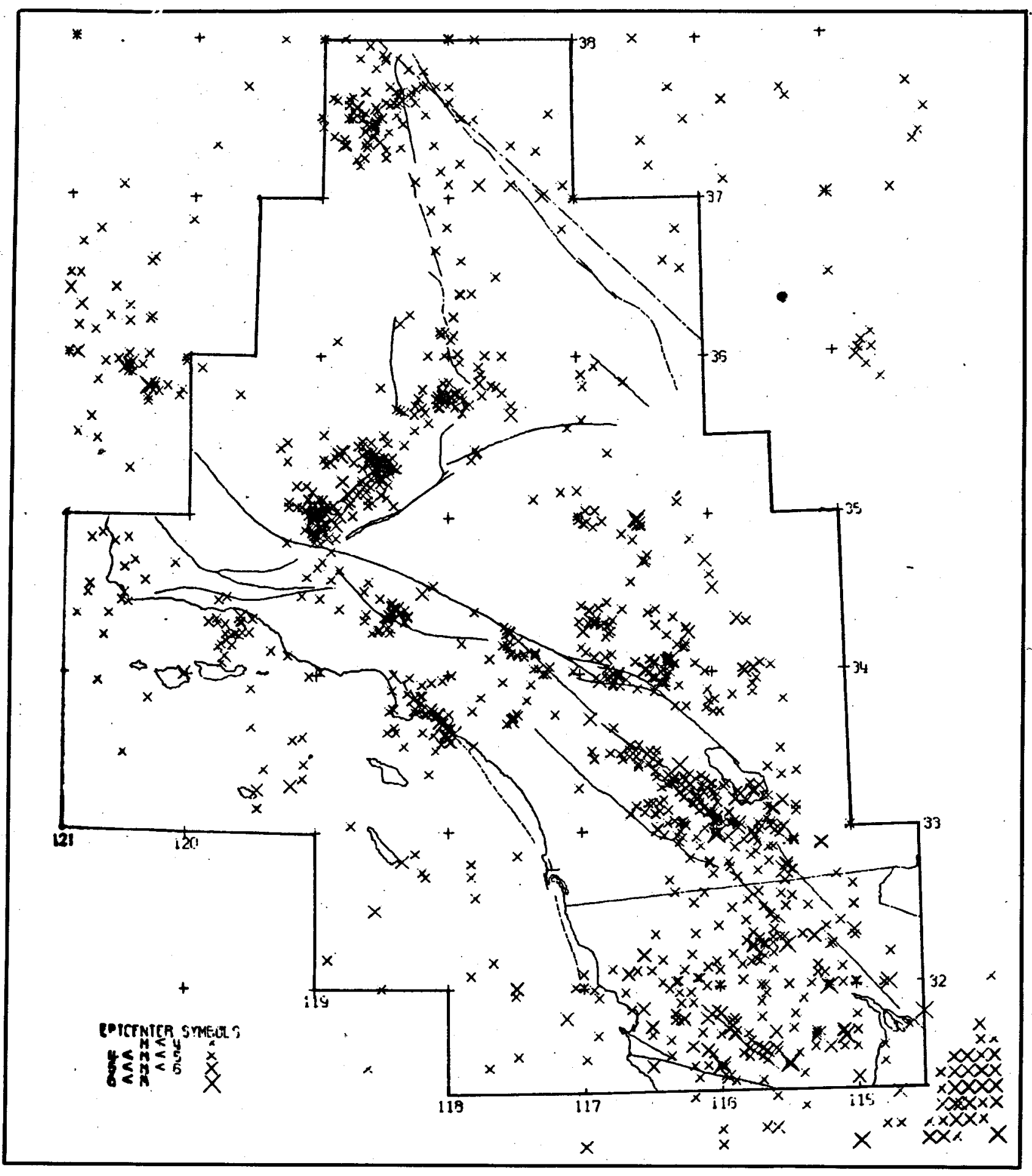

FIGURE NO.17

EPICENTERS OF EARTHQUAKE EVENTS IN SOUTHERN CALIFORNIA OF MAGNITUDE 4 OR GREATER FROM 1932 THROUGH 1972 (25) 
moving right laterally at the cumblative rate of approximately $8.0 \mathrm{~cm} / \mathrm{yr}$ (3.1 in/(yr) (62). This figure is a 20-year average of cumulative shear taken from the Peninsular Ranges to the west of the valley to the Chocolate Mountains to the east (70). The actual movement is by no means constant but has varied greatly with time (18) and location in the valley (62).

Earthquakes occurring along the San Andreas Fault system typically have focal depths of 5-8 km (3.1-5.0 mi), which is approximately the basementsediment interface. Events generally occur on nearly vertical fault planes and are frequently associated. with Quatemary fault scarps. A limiting depth for hypocenters in the valley is about $12-15 \mathrm{~km}(7.5-9.3 \mathrm{mi})$ because at depths greater than this the high thermal gradients generate sufficiently high temperatures to cause the rocks to move plastically in response to stress; in the geothermal areas of the valley this limiting depth is lower (II).

\section{THE IMPERIAL VALIEY EARTHQUAKE OF 1940}

This was the most significant earthquake to have occurred in the Salton Trough in terms of human disturbance. Damage caused by the earthquake extended into Baja California (Mexico), the adjacent Yuma Valley and the Salton Sea area to the north. The shock could be felt for a radius of about $180 \mathrm{~km}$ (112 mi). Casualty reports show that seven persons were killed by the collapse of weak structures, one person burned to death and one died later from injuries. Damage was estimated at 5-6 million dollars, including loss of crops due to interruption of water services and serious damage to all towns of central and southern Imperial Valley. 
The published magnitude for the earthquake was 6.7 but this was later revised to 7.0 (59). The focal depth was shallow and the dominant motion was right lateral displacement along the Imperial Fault (Figure No. 18). Surface faulting could be traced for miles northwest and southeast of the epicenter but the character of the traces was variable. Northwestward, the fault displacement gradually diminished from $1.5 \mathrm{~m}(4.9 \mathrm{ft})$ offsets near El Centro to $15 \mathrm{~cm}$ (5.9 in) near Brawley. The fault trace curved and splayed northwestward until no evidence of surface faulting could be found north of Brawley. Southeastward, the trace was nearly straight and offsets gradually diminished until none could be found $25 \mathrm{~km}$ (15.5 mi) south of the border.

\section{SWARM ACTIVITY AND TECTONIC IMPLICATIONS}

Earthquake swarm activity is common in the valley; in many cases, swarms occur on the same faults as major shocks (27). Swarms that have occurred since 1969 have been studied carefully and these have yielded a wealth of data on the structure and tectonics of the area.

Figure No. 19 gives epicenters for seismic events in the Imperial and Mexicali Valleys during April and May 1969. These earthquakes were recorded shortly after an extensive seismic net in the Salton Trough region was established by Cal Tech. From these recordings, as well as from previous recordings, and other geological and geophysical data, Mexican and United States scientists were able to draw some conclusions about the formation of the Salton Trough. They proposed a model that related the opening of the Gulf of California to motion along the San Andreas Fault System. In this model (Figure No.6) the San 


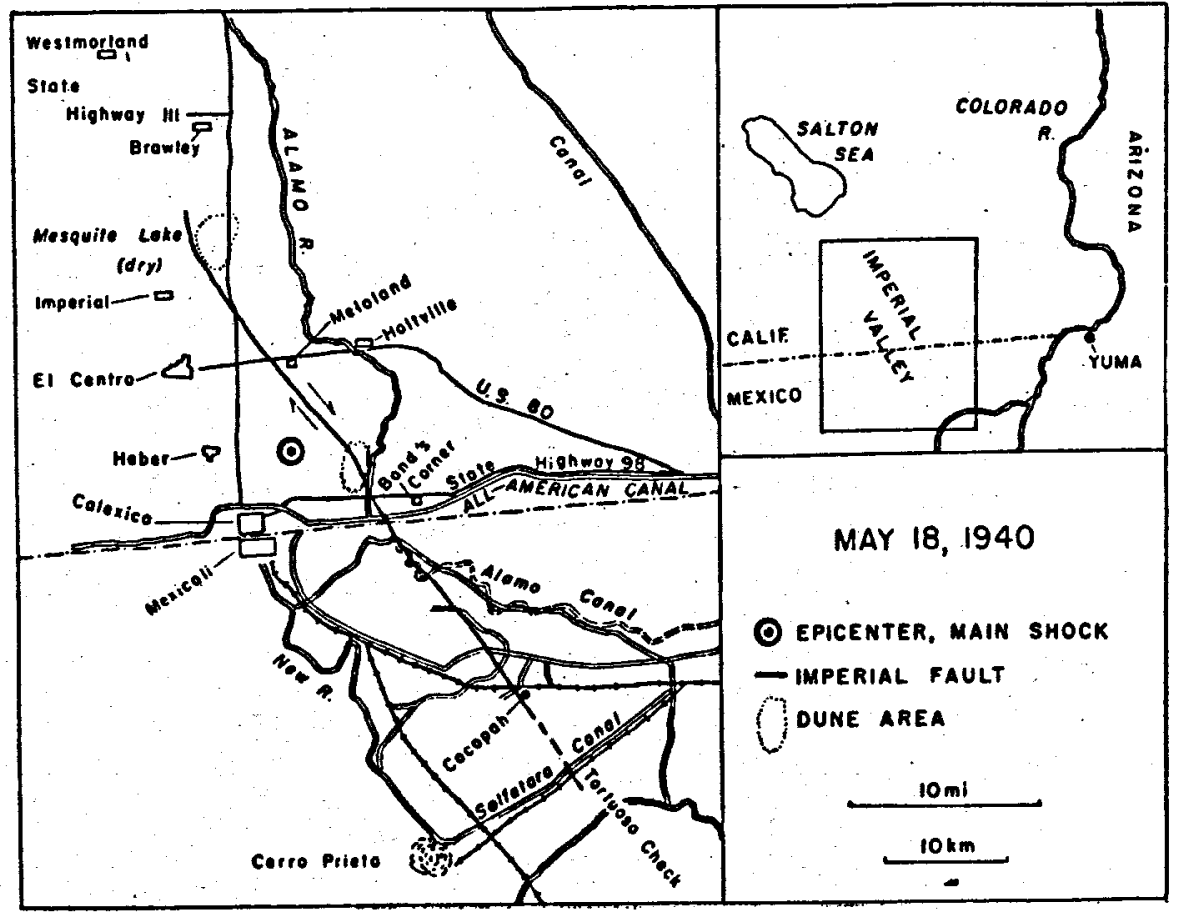

FIGURE NO.18

IMPERIAL VALLEY EARTHQUAKE, 1940. MAP SHOWING

LOCATION OF FAULT, INSTRUMENTAL EPICENTER, ETC.(59) 


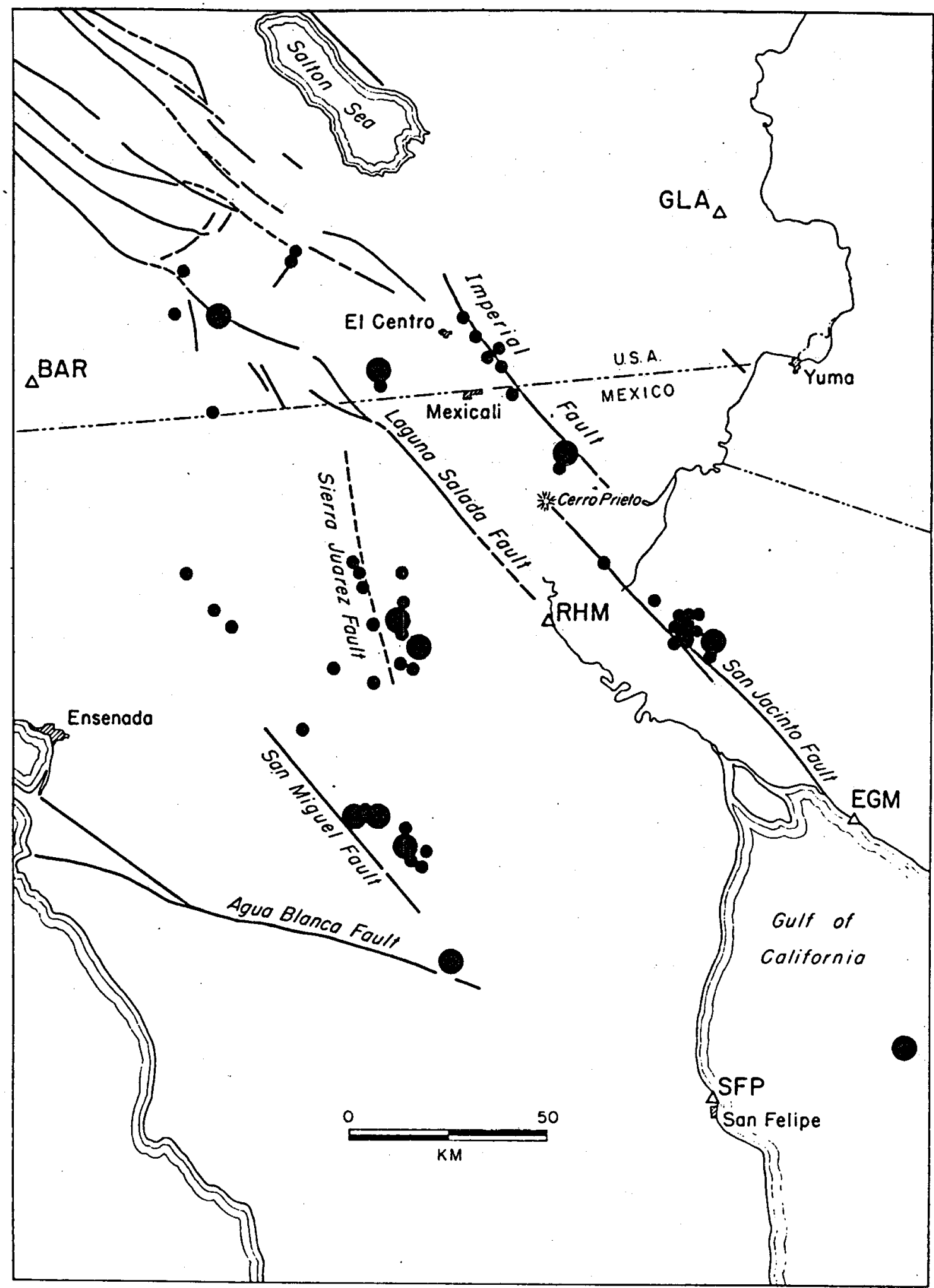

FIGURE NO. 19

SEISMOGRAPHIC STATIONS IN NORTHERN BAJA CALIFORNIA, MEXICO IRHM, EGM, SFP) AND. SOUTHERNMOST STATIONS OF CAL TECH NETWORK IN SOUTHERN CALIFORNIA (BAR, GLA) (40) 
Andreas Fault System forms a transform plate boundary. that connects the divergent plate boundaries in the Gulf of California and the Pacific Dcean north of San Francisco. In the Salton Trough the San Andreas forms several discontinuous segments separated by continental spreading centers. These produced continental spreading centers which include Salton Buttes, North Brawley and Cerro Prieto, all generally areas of high heat flow, young volcanism, high seismicity and crustal thinning and extension. The mechanism for local crustal spreading, suggested from fault plane solutions, involves an echelon nomal and strike-slip faults trending oblique to the regional transform faults. Motion along these faults could account for the observed crustal, rifting.

Figure No. 11 gives epicenters of Imperial Valley earthquakes from June, 1973 to May, 1974. This period was the first year of operation of the U.S.G.S.-Cal Tech sixteen-station seismic net in the valley. Several swarms were recorded during this period near Brawley, Salton Buttes and near El Centro on the Imperial Fault. The figure gives a picture of the annual regional seismicity although coverage was not uniform for earthquakes smaller than Magnitude 2. These earthquake data tend to verify earlier observations on regional seismicity $(40)$ and establish definite fault traces for the Brawley and Imperial faults. Focal depths for these earthquakes along a section of the Imperial fault are given in Figure No.- 20 .

During late January, 1975 the Brawley area was the site of a major earthquake swarm. Epicenters fram a five day period are given in Figure No. 21. Analyses of focal depths, temporal migration, and first motion of earthquake yielded the following observations: (1) Earthquake focal depths were shallower inside the Brawley thermal area than outside, probably because 


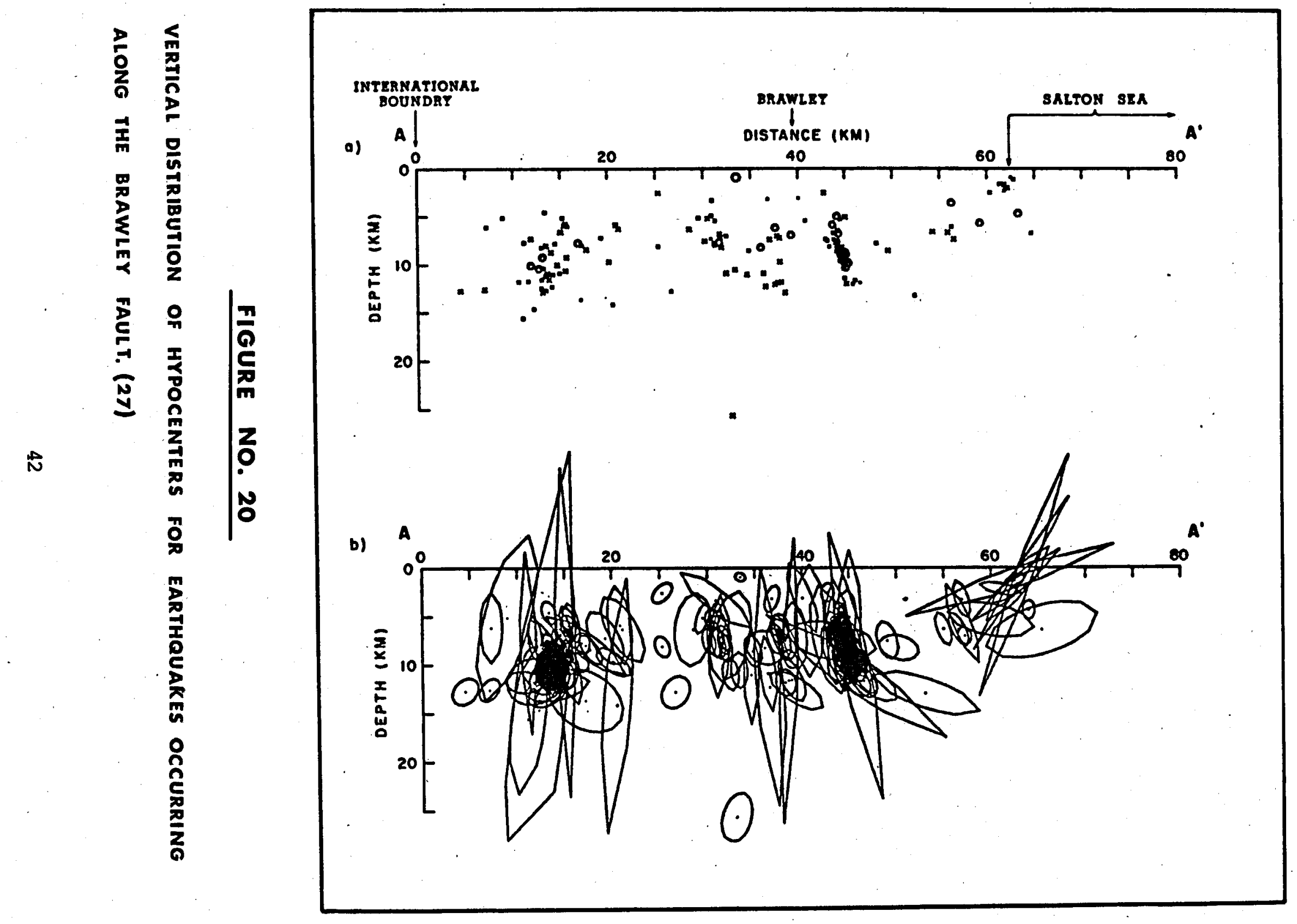




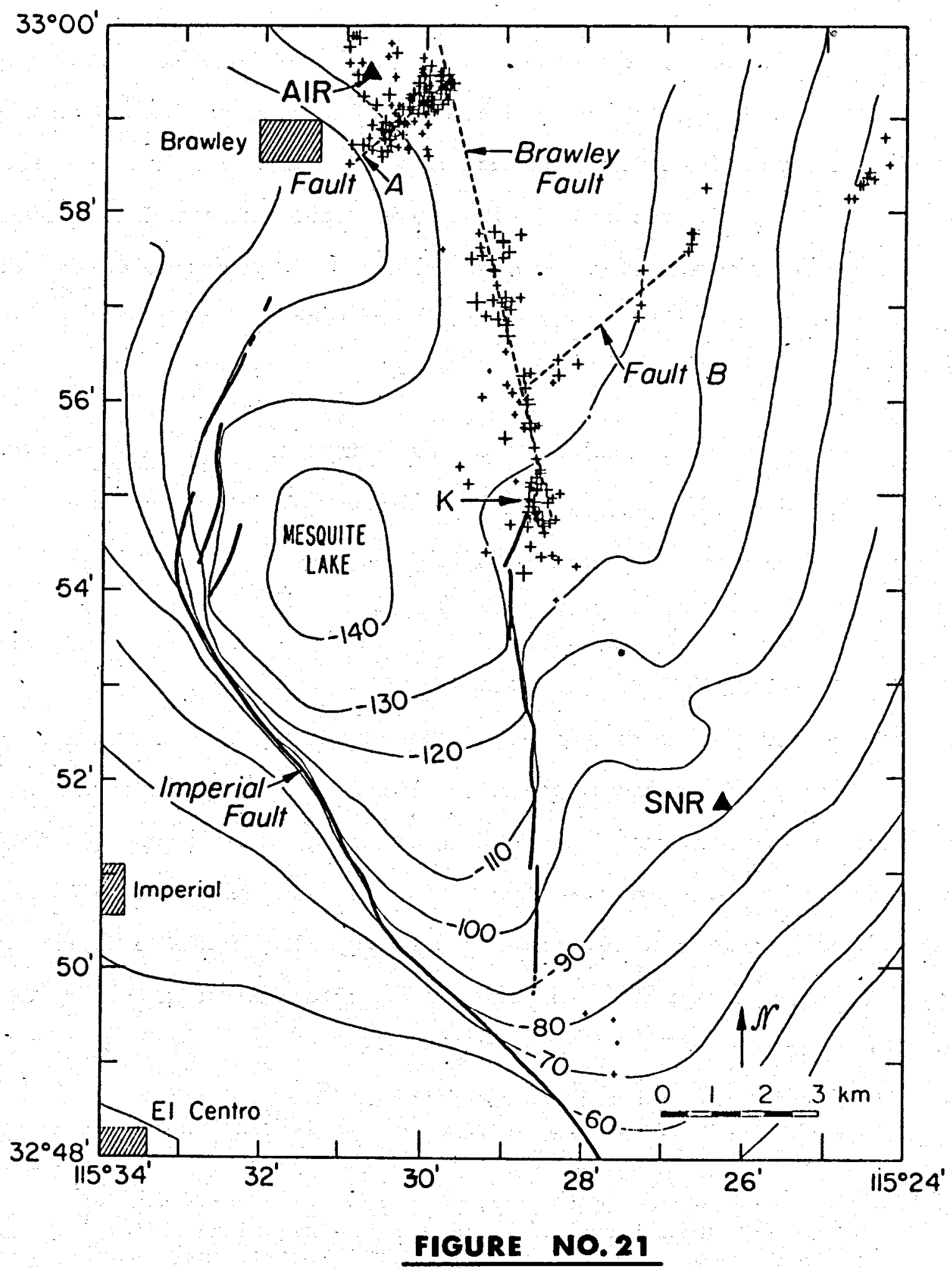

EPICENTERS OF EARTHQUAKES OF THE BRAWLEY SWARM JANUARY 1975 (31) 
higher subsurface temperatures cause deeply buried rocks to move plastically in response to stress; (2) In the Brawley field many earthquakes occurred along northeastward-trending left lateral and normal faults (Faults A and B in Figure No. 21, for example). This type of motion is assumed responsible for the observed spreading at Brawley. Figure No. 22 illustrates the number of earthquakes along the. Brawley fault with respect to depth. Most earthquakes occurred between 3 and $8 \mathrm{~km}$ (1.9 and $5 \mathrm{mi})$ in depth.

Some researchers (17) have included Heber as another region of crustal spreading, but its position relative to transform fault segments makes this assertion doubtful. Earthquake activity at Heber is also noticeably less than at North Brawley or Salton Buttes $(25,26,27)$.

REILATION OF EARIHQUAKES TO GEOTHERMAL ACTIVITY

Several studies have shown that there is a correlation between microearthquake activity and geothermal anomalies $(36,39)$. In the Imperial Valley, the correlation is unusually high. High levels of microearthquake activity are found at Saltan Buttes (26), North Brawley (31) and East Mesa (12). To date, it is unknown whether such a relationship also exists at Heber. In any case, several remarks can be made about earthquakes in the Valley's geothermal areas:

- Shocks are generally smaller in magnitude and more frequent in geothermal areas than other areas in the same tectonic setting (69).

- Faults related to the microearthquakes may serve as conduits for circulating brines. At the Salton Buttes, for example, it was observed that $\mathrm{C}_{2}$ wells began emitting large quantities of gas just after earthquakes in the 1930's. 


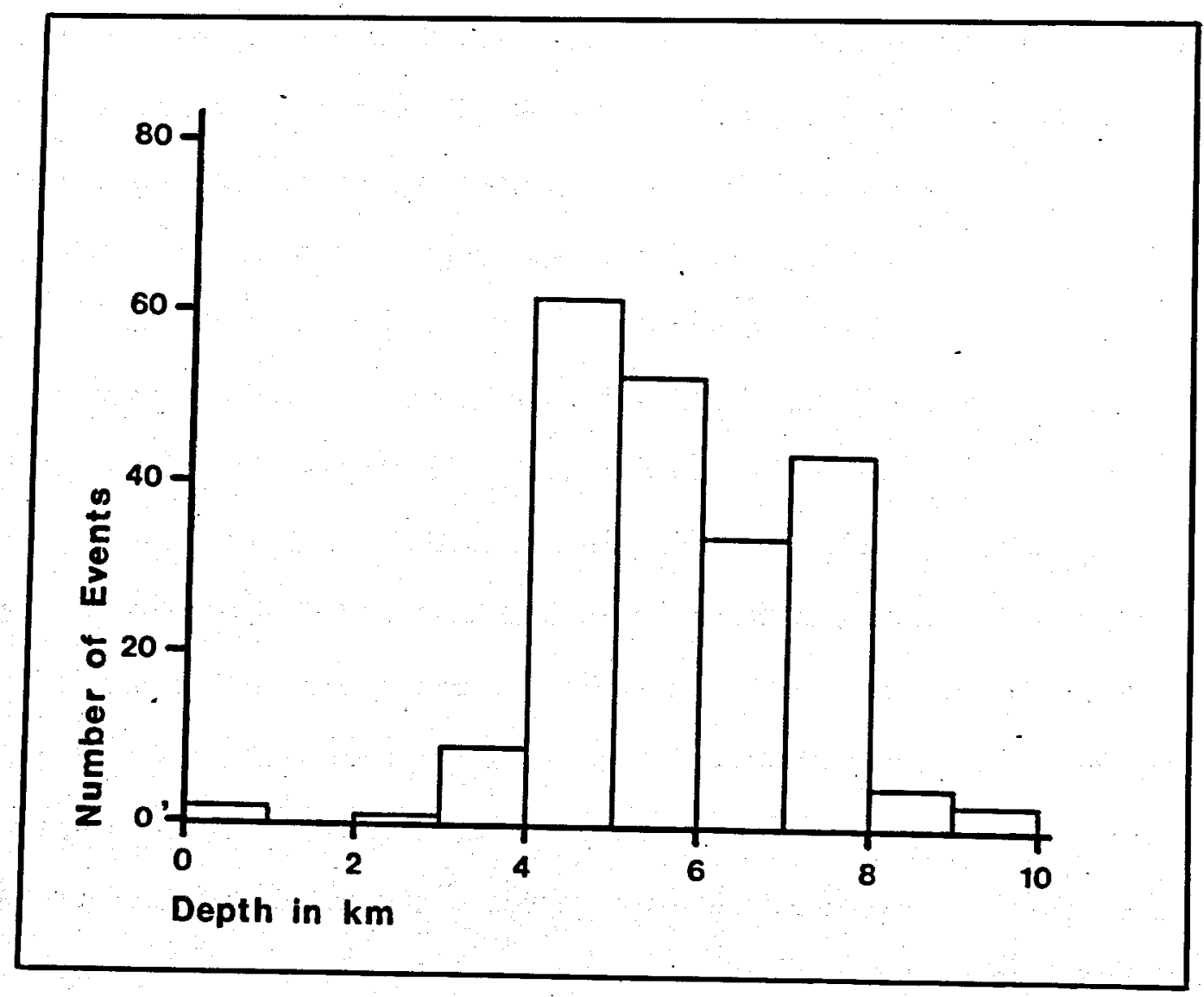

FIGURE NO. 22

DEPTHS OF EARTHQUAKE HYPOCENTERS FOR EVENTS OF THE BRAWLEY SWARM JANUARY, 1975(31) 
- Earthquake focal depths are usually shallower in geothermal areas than in other seismic areas, implying that microearthquakes are related to geothemal processes. Also, the amplitude of earthquakes within geothermal areas appears to be smaller than outside.

The possibility of triggering earthquakes by geothermal production and reinjection is of some concern. Although existing producing fields at the Geysers, California and Wairakei, New Zealand have long been associated with earthquake activity, production has not been hampered by earthquakes and no associations have been drawn between geothermal production and earthquake activity. Existing oil field and waste well data have yielded clues to the effect that fluid injection has on triggering earthquakes. Of the thousands of existing oil field and waste injection wells, only two instances of earthquakes triggered by fluid injection have been cited in the literature. One of them is at the Rocky Mountain Arsenal waste disposal well near Denver, Colorado and the other is at the Rangely Oil Field in northwestern Colorado (52). Figure No. 23 is a plot of the epicenters of injection triggered earthquakes at Rangely where events registered up to Magnitude 6. Earthquakes are inferred to be caused by an increase in pore pressure that results in shear failure therefore reducing the nomal stress across fracture surfaces. Regional tectonics, the stress field, and rock properties at Heber are vastly different from Rangely. Therefore, the Rangely experience is not necessarily applicable to Heber.

In the Heber area the effect that production might have on earthquake activity may only be speculated. Withdrawal of fluids may alter the deep ground water pattern and perhaps even the surface flow rate (16). The effect of these alterations on the tectonic stress regime is unknown. Any attempt 


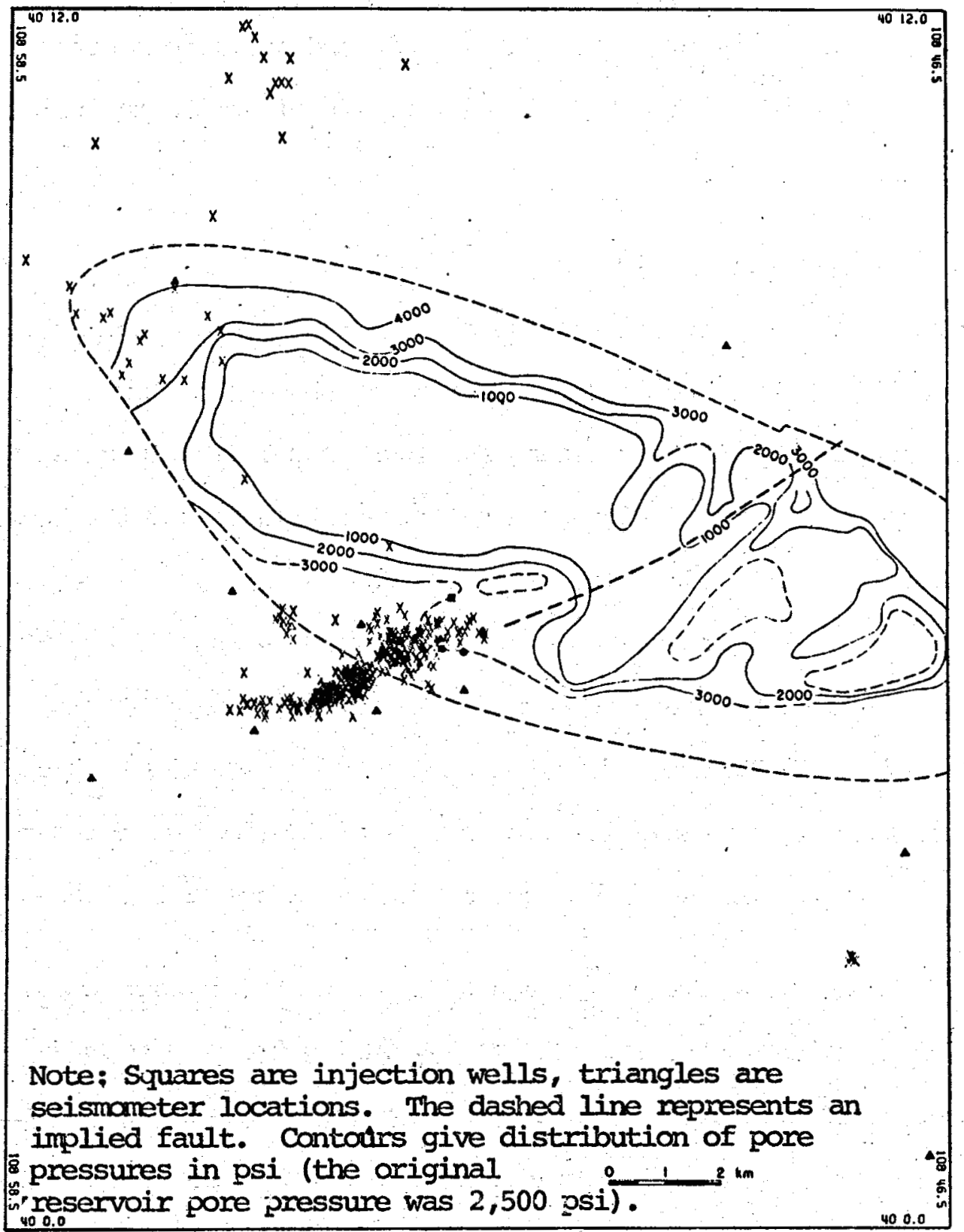

FIGURE NO. 23

EPICENTERS OF INJECTION-INDUCED EARTHQUAKES AT RANGELY, COLORADO (52) 
to determine these effects and the effects of fluid reinjection will require several years of continuous seismic and geodetic monitoring during which background seismicity and the location of active faults must be established.

SEISMIC RISK OF THE HEBER AREA

Figure No. 24 is a strain release map for Southern California during the period 1933-1963. The shadings depict the numbers of equivalent Magnitude 3 earthquakes thereby expressing strain release. The Imperial valley is shown to be an area of high regional strain release and the Heber area is part of this high belt. The diagram suggests that near Heber a typical 100 sq $\mathrm{km}$ (39 sq mi) region could expect between 64 and 256 equivalent Magnitude 3 earthquakes every 30 years. The same amount of strain would be released by 10-40 Magnitude 4, 2-10 Magnitude 5 or 0.25 to 2.0 Magnitude 6 earthquakes, or by aseismic creeping. The diagram does not suggest how the strain will be released, but rather how much should be released.

In Figure No. 25 a frequency-magnitude relation (recurrence curve) is plotted for earthquakes in the Imperial Valley during the period 1932-1972. Recurrence curves are useful in establishing a seismicity pattern for an area and have been used as guides for determining regional seismic risk. If frequencies of different magnitude earthquakes form a linear pattern, such as in Figure No. 25, then the frequency of their occurrence in the future can be predicted with reasonable certainty. This does not mean, however, that the extent of their occurrence can be predicted. When points fall off the curve such as the lower magnitude events in Figure No. 25, it 


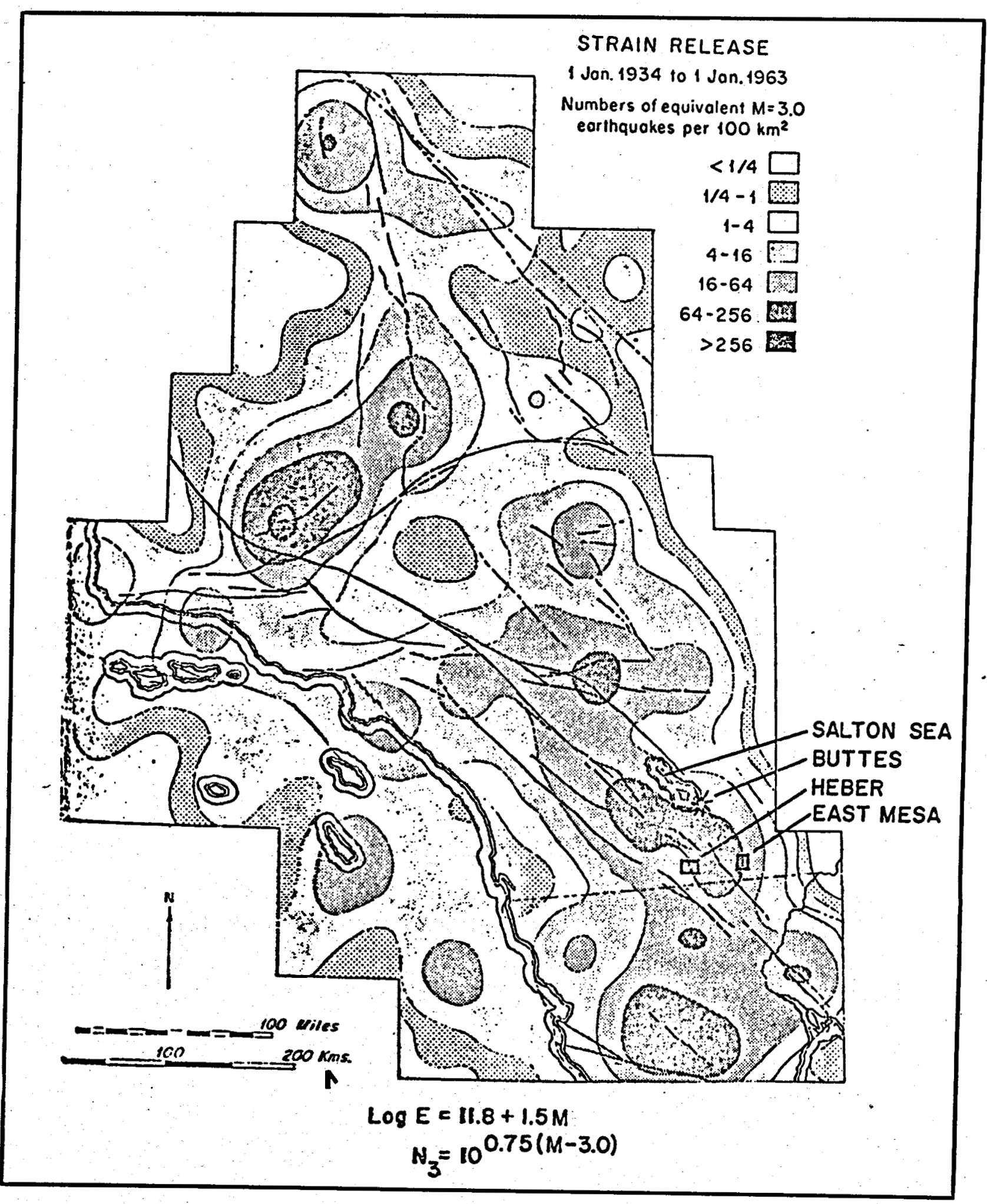

FIGURE NO. 24 


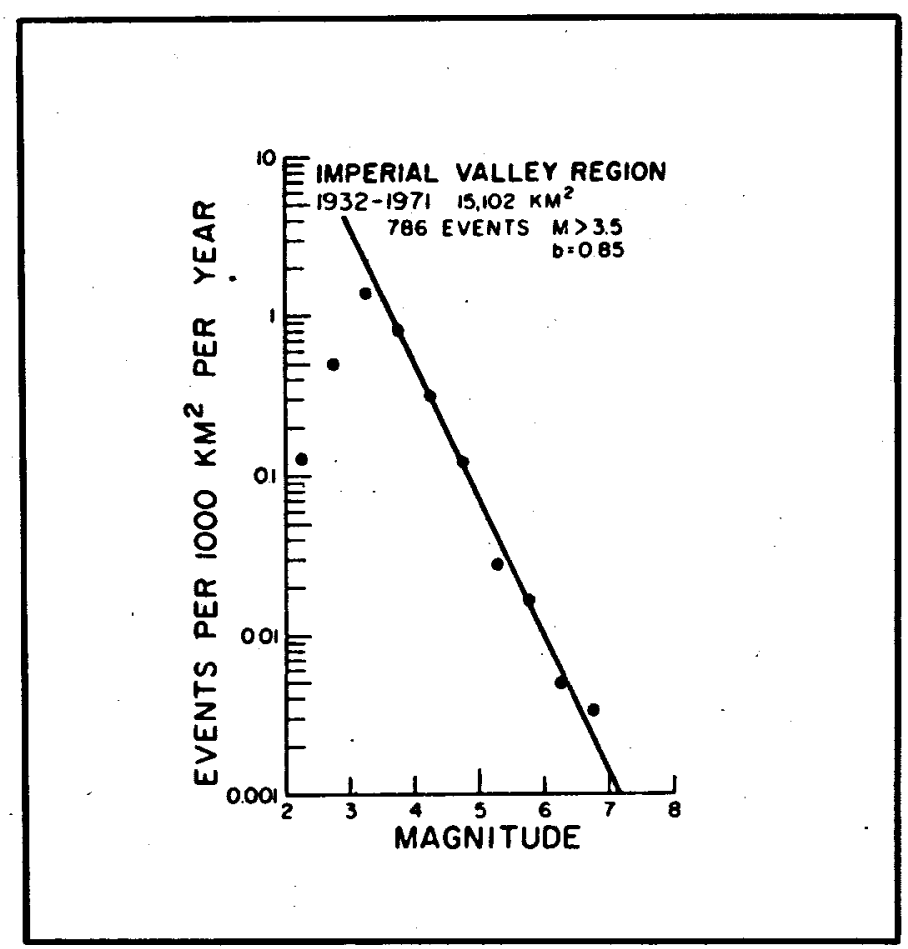

FIGURE NO. 25

RECURRENCE CURVE FOR EARTHQUAKES IN THE IMPERIAL

VALLEY REGION, $1933-1972$ (25) 
often means that data compilation for those earthquakes is incomplete. For the Imperial Valley, Figure No. 25 shows that a Magnitude 6 earthquake, for example, can be expected about every 100 years, a Magnitude 5 every ten years, and lower magnitude shocks much more frequently. The figure also provides a statistical recurrence curve for earthquakes in the Imperial Valley per $1,000 \mathrm{~km}^{2}\left(622 \mathrm{mi}^{2}\right)$.

However, a word of caution must be expressed with regard to the specific applicability of the general recurrence curve in Figure No. 25 to a small area such as Heber. The activity used for constructing the recurrence curve is representative of the sum of all quakes in the valley. However, these took place along the active faults in the valley. No known faults occur in Heber or near it. Hence, the recurrence curve may have a limited usefulness in predicting earthquake occurrence in the Heber area itself: Adequate data do not exist on the local stress pattern and the strength of the formation at Heber to. allow predictions regarding possible injectioninduced seismicity. However, it appears unlikely that injection of waste brine will significantly increase seismicity in the Heber area; no faults have been detected as yet under Heber and the increase in pore pressure around injection wells will not be excessive because of the relatively high permeability of the Heber reservoir.

Figure Nos. 24 and 25 imply that the Imperial valley is a zone of relatively high seismicity and structures planned for the valley should be designed with this in mind. The following section presents a discussion of the maximum ground acceleration due to earthquakes to be expected at Heber and its implication in designing structures. 
MAXTIMUM GROUND ACCELRATION

Figure No. 26 shows estimates by various authors of the maximum ground acceleration caused by an earthquake of Magnitude 6.5 as a function of the distance from the causative fault. As the distance from the causative fault increases the maximm acceleration decreases. It shows, for example, that an earthquake of Magnitude 6.5 occurring at a distance of $20 \mathrm{~km}$ (12.5 mi) from a given structure can cause an acceleration of about 0.09 to $0.12 \mathrm{~g}$. This difference in the estimate of maximum acceleration is due to the effects of different source mechanisms, geologic environments, travel paths and local site conditions. Figure Nos. 27 through 29 show similar estimates by the same authors for earthquakes of Magnitude 7, 7.5 and 8, respectively. Figure No. 30 shows reasonable average values of maximum acceleration for earthquakes with a focal depth of 10 to $15 \mathrm{~km}(6.2$ to $9.3 \mathrm{mi})$.

It should be mentioned that same degree of judgment must be exercised in applying these estimates to any particular site, based on the knowledge of local site conditions. It may be noted that except for locations very near the causative fault for earthquakes with Magnitude 8 or greater, the maximum rock accelerations in Figure No. 30 are substantially lower than the maximum ground accelerations proposed by Housner (28) and Cloud (10), which reflect the amplifying influence of many soil deposits. The acceleration reoord of the $1940 \mathrm{El}$ Centro earthquake (Figure No. 31) shows a maximum acceleration of $0.32 \mathrm{~g}$. This value is in good agreement with the maximm anticipated acceleration on soil depasits shown in Figure No. 32. However, Figure No. 31 also suggests that if the recording station had been located on a rock outcrop, the maximum recorded acceleration would have 


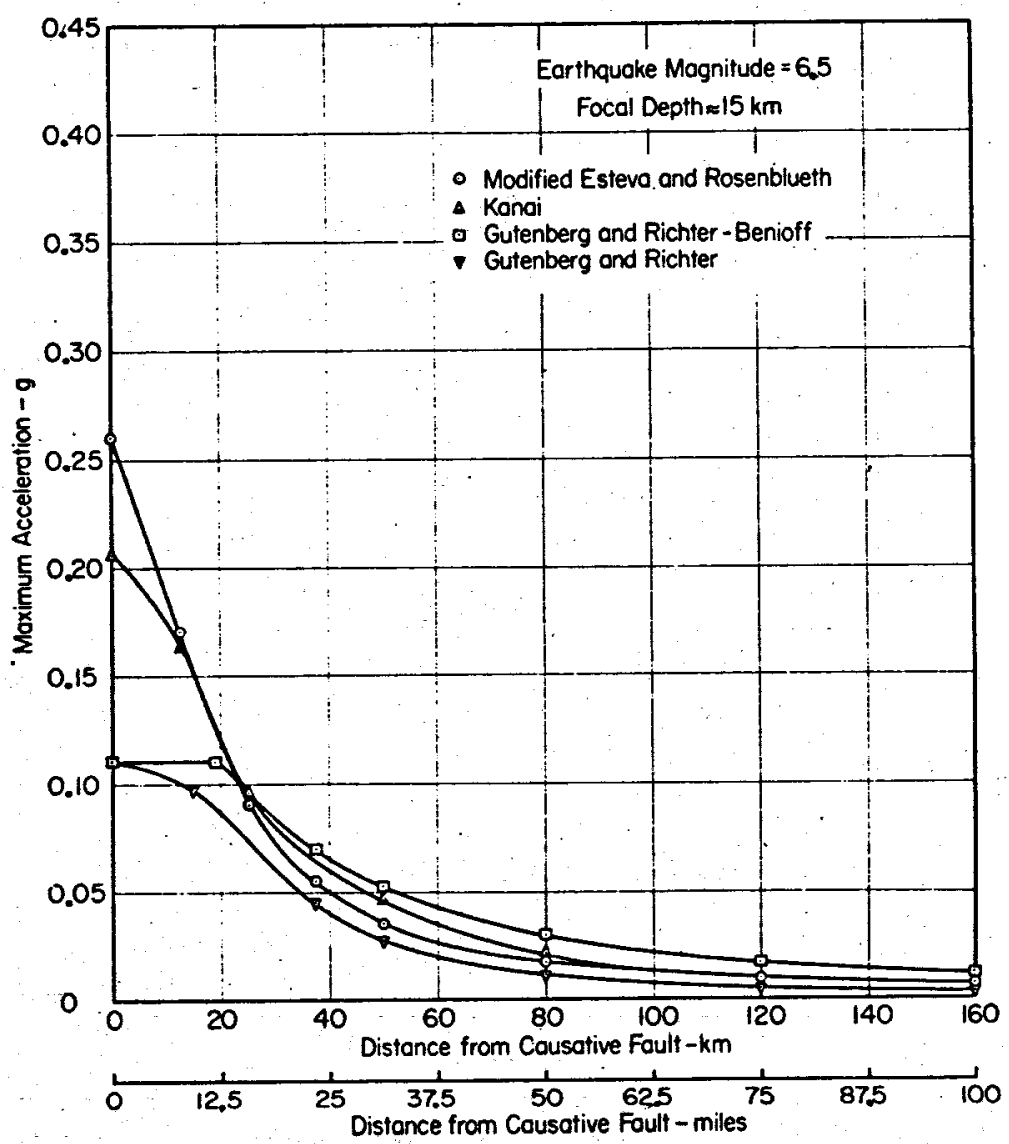

FIGURE NO. 26

\section{ATTENUATION OF MAXIMUM ROCK ACCELERATION WITH INCREASING DISTANCE FROM CAUSATIVE FAULT, $M=6.5$ (63)}




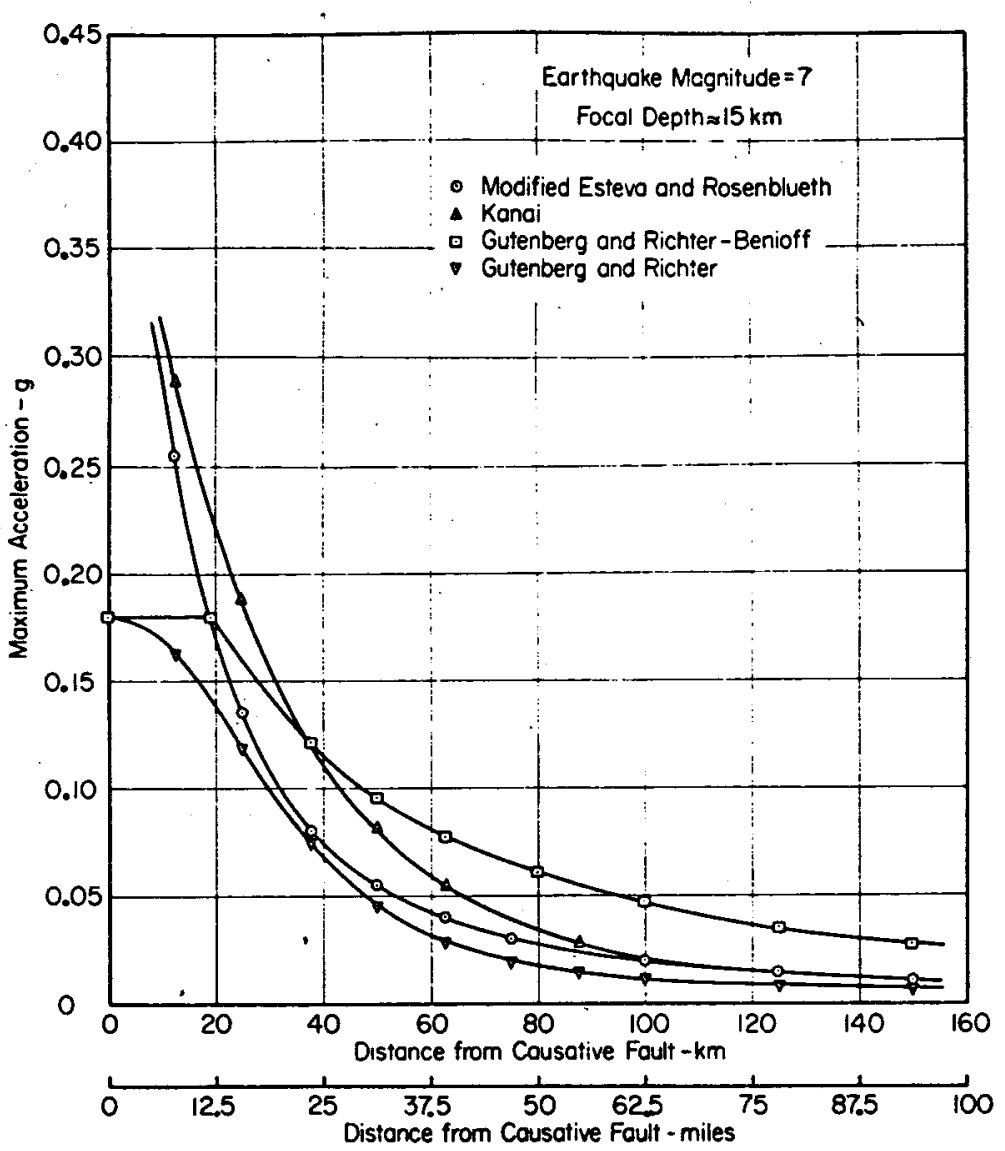

FIGURE NO. 27

ATTENUATION OF MAXIMUM ROCK ACCELERATION WITH INCREASING DISTANCE FROM CAUSATIVE FAULT, $M=7$ (63) 


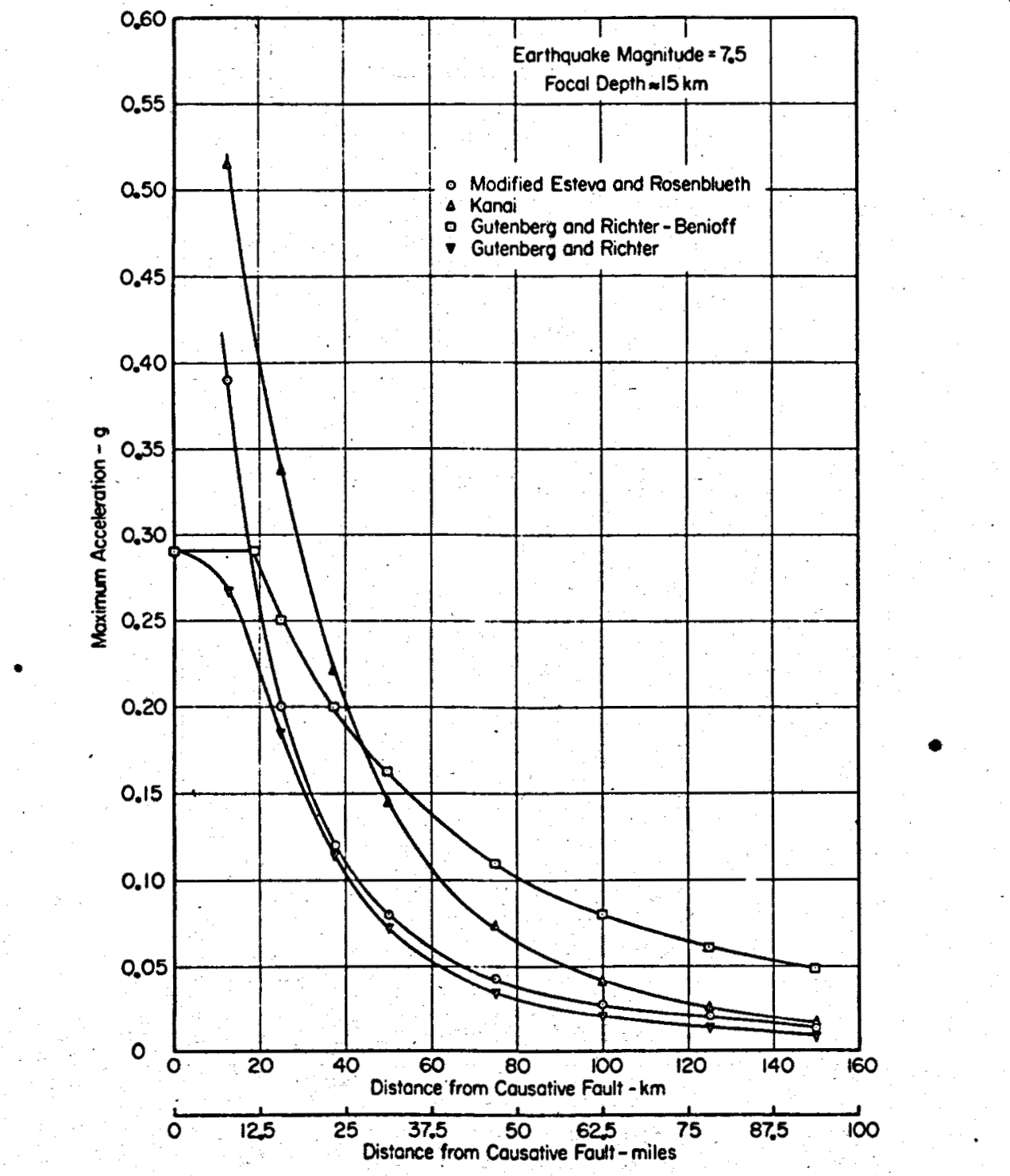

FIGURE NO. 28

ATTENUATION OF MAXIMUM ROCK ACCELERATION WITH INCREASING DISTANCE FROM CAUSATIVE FAULT, $M=7.5$ (63) 


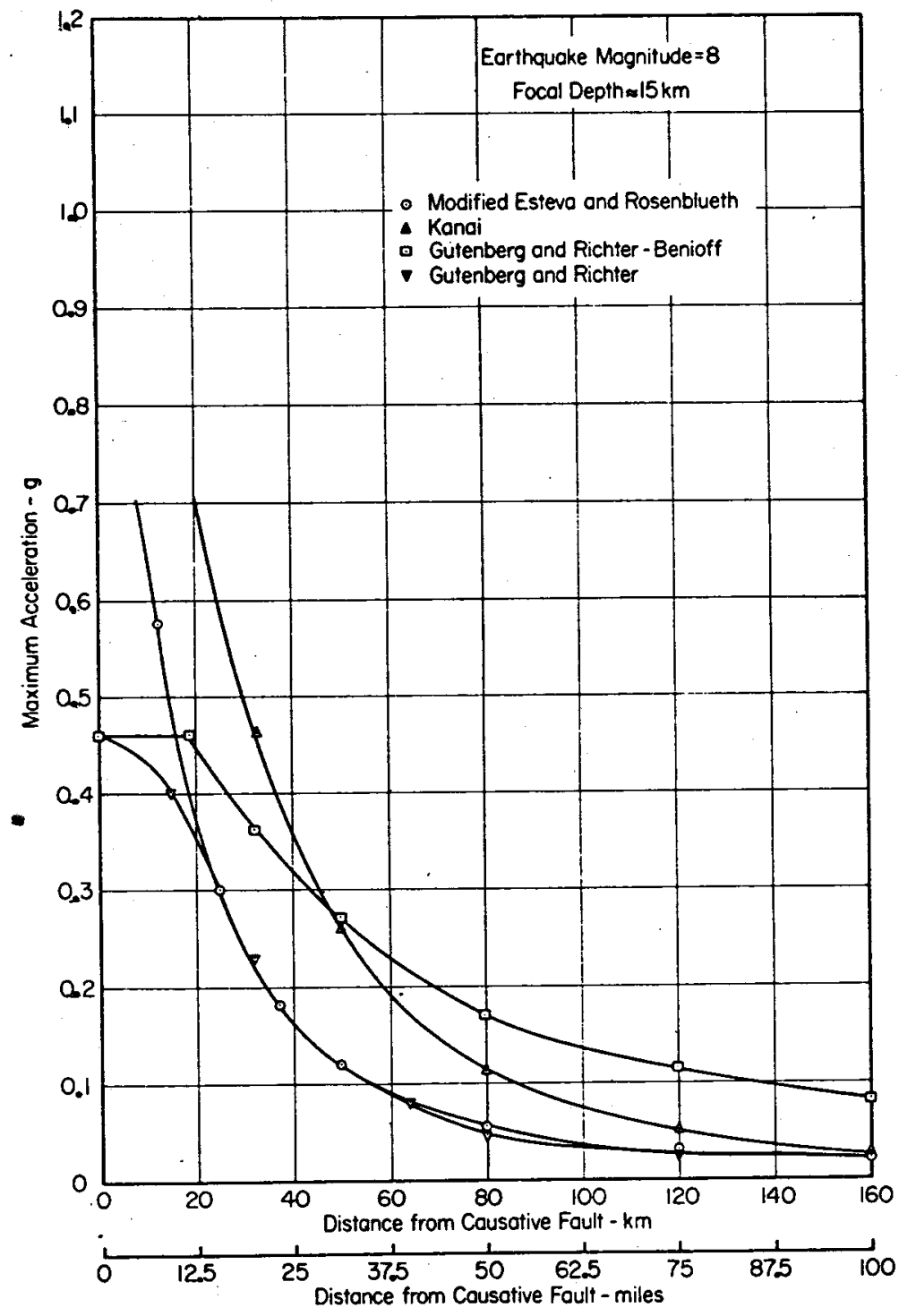

FIGURE NO. 29

\footnotetext{
ATTENUATION OF MAXIMUM ROCK ACCELERATION WITH INCREASING DISTANCE FROM CAUSATIVE FAULT, $M=8$ (63)
} 


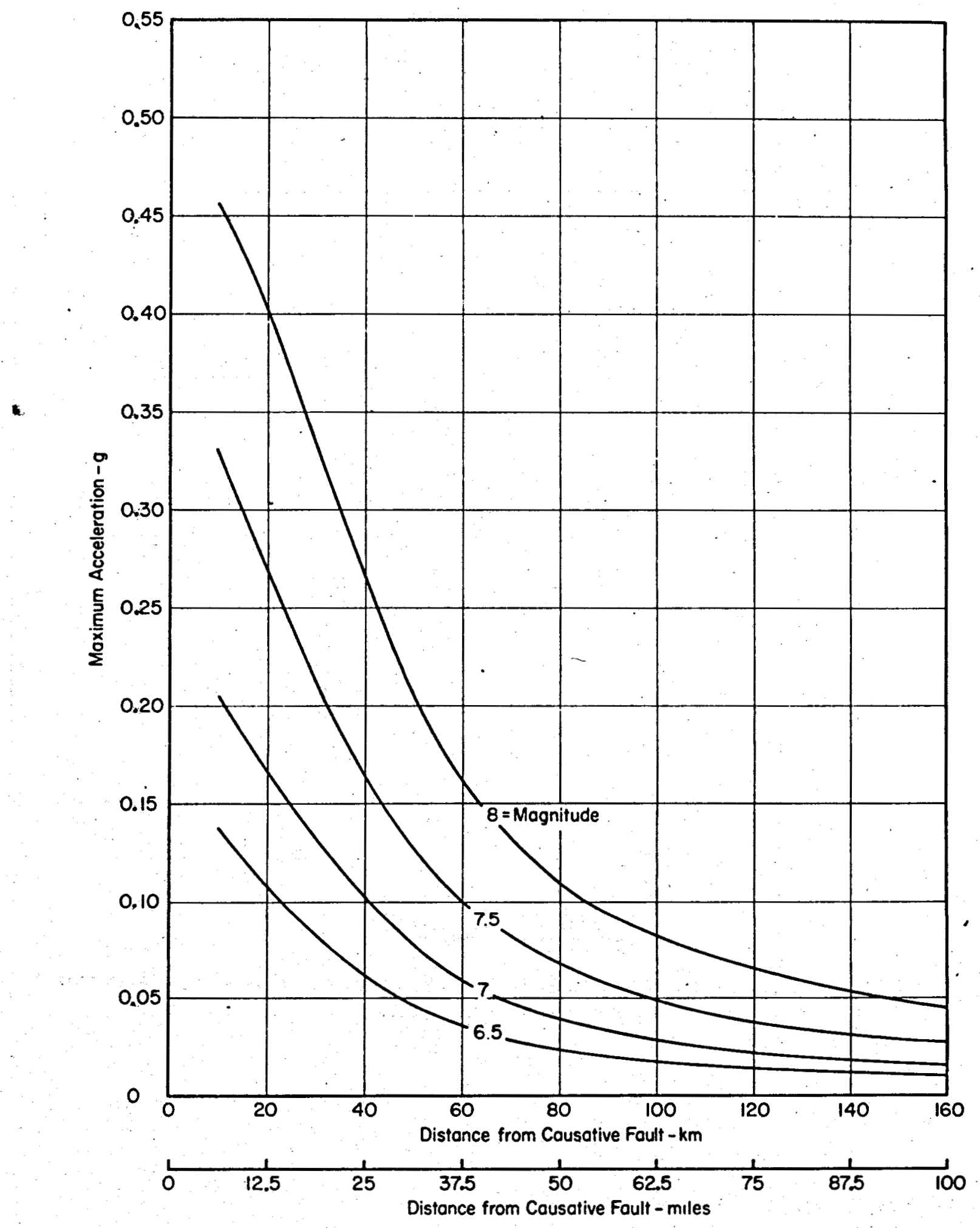

FIGURE NO. 30

VARIATION OF MAXIMUM ACCELERATION WITH EARTHQUAKE MAGNITUDE AND DISTANCE FROM CAUSATIVE FAULT (63) 


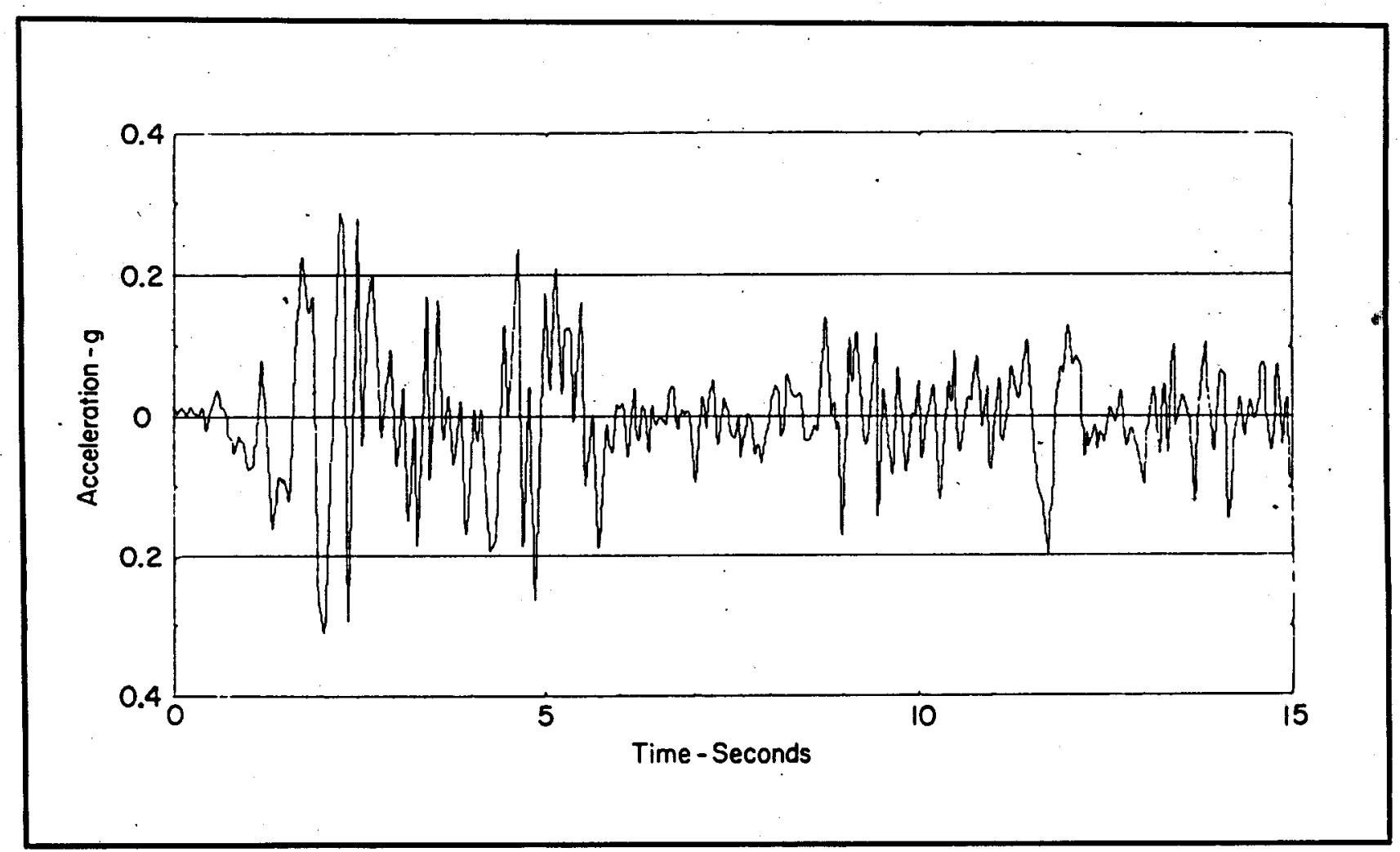

\section{FIGURE NO. 31}

GROUND ACCELERATIONS RECORDED AT EL CENTRO (N-S COMPONENT) IN EL CENTRO EARTHQUAKE OF 1940 (63) 


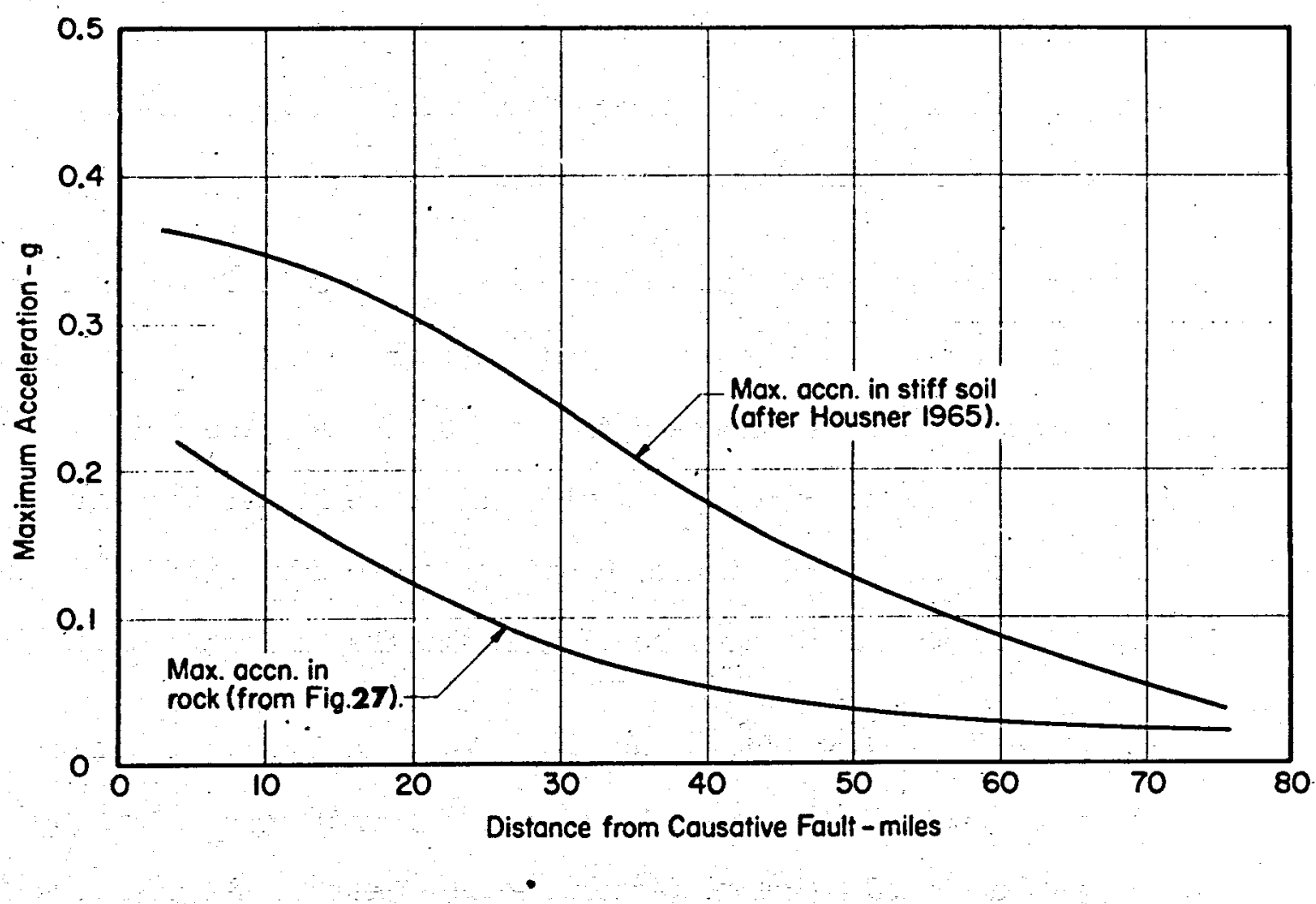

FIGURE NO. 32

COMPARISON OF MAXIMUM ACCELERATION

IN ROCK AND STIFF SOIL DEPOSITS FOR EARTHQUAKE MAGNITUDE 7 (63) 
been only about $0.20 \mathrm{~g}$. In addition, Housner (28) has claimed that the upper bound for the maximum acceleration recorded at El Centro, during the May 1940 earthquake, is still higher ( about $0.50 \mathrm{~g}$ ). This argument highlights the difference between anticipated rock motions and the recorded ground surface motions and these differences may be attributed to the modifying influence of the soil deposits underlying the recording station on the motions developed at the ground surface.

Data presented by Duke and Leeds (15) show that the soil deposits at the recording station at $\mathrm{El}$ Centro consists of about $30 \mathrm{~m}$ (100 ft) of stiff clay underlain by several thousand feet of sediments. The maximum accelerations recorded over such sites would tend to be higher than anticipated for sites on rock outcrop. Hence, Housner's curve for stiff soil conditions (Figure No. 32) is more applicable for the El Centro site.

The preceding discussion points out the wide variations in recorded accelerations that can be caused by local site conditions. Still greater scatter may be caused by other factors, "such as earthquake source mechanisms and elastic wave travel paths. It is with these uncertainties in mind that Schnabel and seed (61) conducted further research into the relationships between maximum accelerations and the distance from the causative fault. The results of their. work are shown in Figure No. 33, which shows all possible ranges of expected accelerations, and is partly based on additional data following the February 1, 1971 San Fernando earthquake. Figure No. 34 compares data gathered during the San Fernando earthquake with previous results. Schnabel and Seed's (61) analysis of the data also 


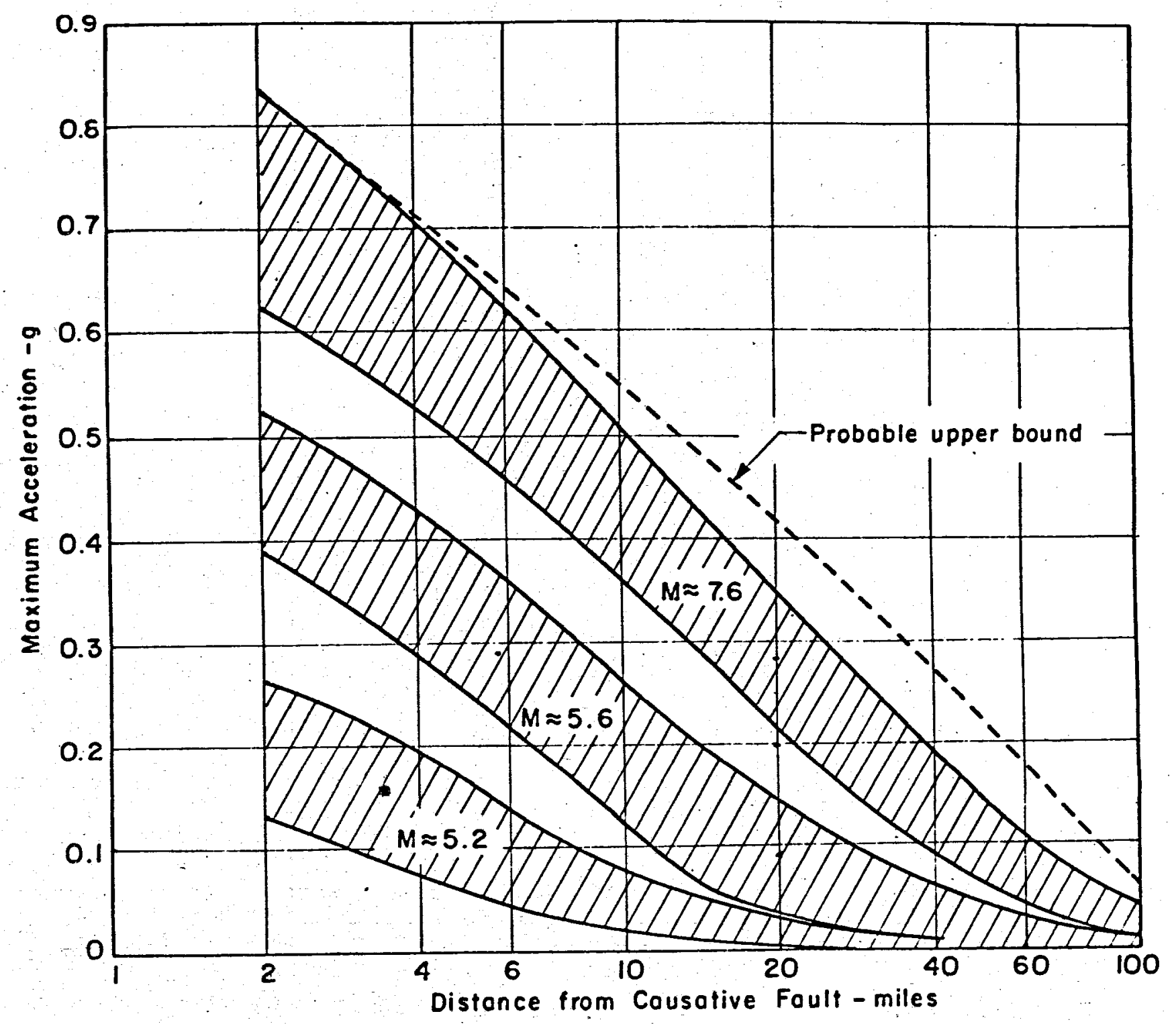

FIGURE NO. 33

RANGES OF MAXIMUM ACCELERATIONS IN ROCK 


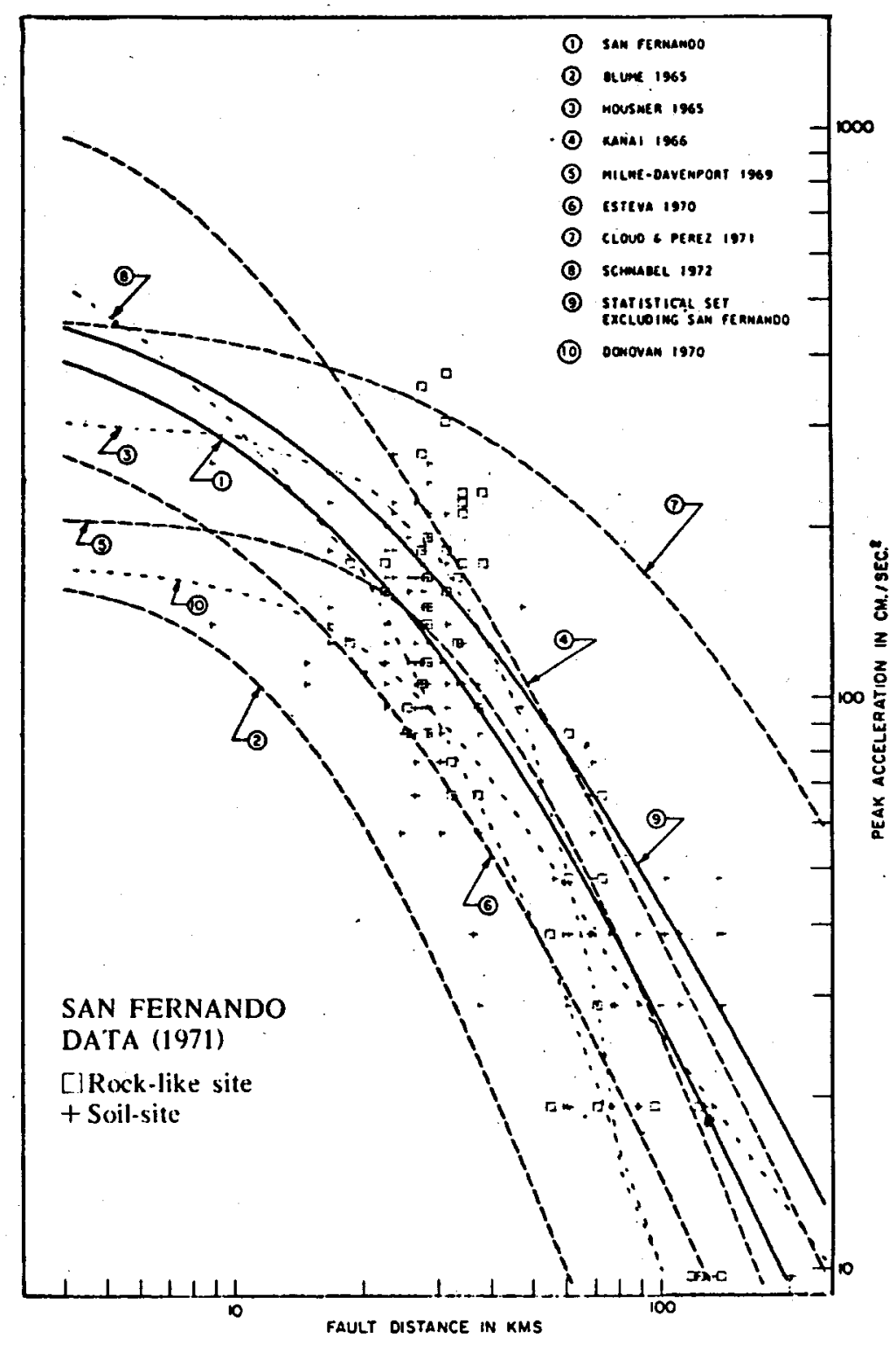

FIGURE NO. 34

ATTENUATION EQUATIONS FOR MAGNITUDE 6.5 COMPARED TO DATA FROM STRONG MOTION STATIONS RECORDING SAN FERNANDO EARTHQUAKE, FEBRUARY 9,1971 (14) 
incorporated new analyatical tools which permit the assessment of rock motions fram records obtained on soil deposits. Their, results (Figure No. 33) are additional data, whereas previous researchers (63) had based their conclusions on very limited data. For this reason, Figure No. 33 should provide more realistic estimates of the maximum ground acceleration.

Comparing information in Figure Nos. 25 and 33, Geononics recommends that a value of $0.375 \mathrm{~g}$ be considered as the minimm design value for the structure at Heber, and that due consideration be given for the possible resonance amplification effect for different design options. It is also recommended that the possibility of liquefaction of near surface sediments in the event of a major earthquake be investigated.

\section{SUBSIDENCE AND GROUND MOTION}

The effect that fluid withdrawal without reinjection has on ground subsidence is well established. Land subsidence related to withdrawal of fluid has been on the order of $10 \mathrm{~m}(32.8 \mathrm{ft}$ ) in Long Beach, $4 \mathrm{~m}$ (13 ft) in the Santa Clara Valley and $2.4 \mathrm{~m}(7.9 \mathrm{ft}$ ) in Houston (39). The Cerro Prieto and Wairakei geothermal operations which do not reinject fluids have also been affected by subsidence problems. Horizontal movements in response to fluid withdrawal have also been documented. In the wilmington oil field, land has been observed to move horizontally $3.5 \mathrm{~m}$ (il. $.5 \mathrm{ft}$ ) during the time of production without concurrent reinjection. Extensive cracks and fissures have also been observed there.

In the Imperial valley ground motion and subsidence exist as part of the tectonic background. In Figure No. 35 triangulation and leveling data show that the valley is moving horizontally in a complex manner and that the 


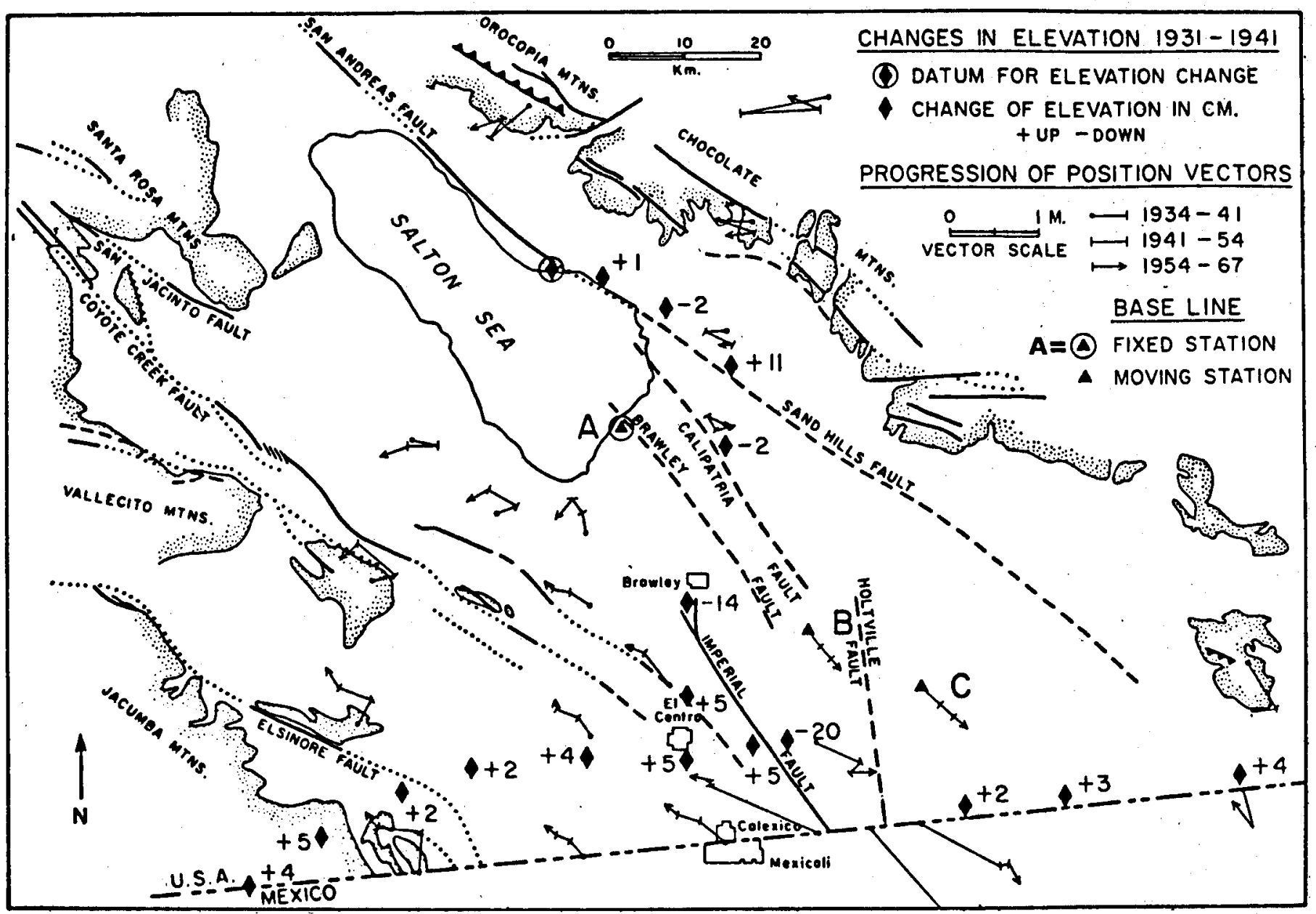

FIGURE NO. 35

GEODETIC MEASUREMENT IN THE IMPERIAL VALLEY FROM 1934 TO 1967 (17) 
central valley is subsiding at a maximum rate of about $1.5 \mathrm{~cm}(0.6 \mathrm{in})$ per year relative to the surrounding mountains. It is clear from this figure that the horizontal motion is far more complex than the assumed right-handed shear model (70) and that the northern and central parts of the valley are showing greatest subsidence. The Brawley area has recently been moving dowriward at the highest rate, which may be related to the large number of recent earthquakes $(26,27)$ and the high strain rate on the Imperial and Brawley faults $(17,31)$. A recent leveling survey by the Chevron Oil Company, according to E. Dobrich in a personal communication in March 1976, suggests that the Heber area is moving up slightly with respect to El Centro but that the dominant motion has been a dowrward tilting northward and eastward.

Iand subsidence problems related to the proposed geothermal development at Heber can only be speculated at this time. Because of the fact that the geothermal fluid would be reinjected after heat extraction, any subsidence due to brine production is likely to be small and most likely no larger than that due to tectonic causes. The effect of subsidence is not likely to prove a significant envirommental concern. The following section is a preliminary study of the subsidence aspects of geothermal power development at Heber.

\section{SUBSIDENCE POSSIBIIITIES AT HEBER}

At the outset of this short-term study of subsidence in the area of the Heber geothermal reservoir, it was considered desirable to discuss subsidence with Chevron Oil Company engineers involved in evaluating the 
reservoir and in forecasting its performance. Through the company, it was learned that a subsidence detection cammittee has been formed in Imperial County. This committee has studied subsidence in connection with agricultural operations. The Imperial Irrigation District surveys and makes profiles of canals and ditches in the county.

Monitoring of the leveling in the valley is continuous. The first order lines are scheduled for surveys biennially. Significantly, the bedrock ties to the west, east, and north of El Centro are considered stable, although this has not been proven. The surveys made to date disclose a slight regional tilt from south to north.

The county surveyor's office knew of no localized subsidence caused by agricultural operations. It also was mentioned that bench marks by law must be established in the areas of geothermal fluid reservoir with local surveys being made periodically. The results are to be related to the major first and second order networks for the purpose of detecting subsidence.

Fluid withdrawal and injection affect reservoir fluid pressures, which, in tưrn, can cause changing land surface elevations. Relating bench mark elevations to net fluid withdrawal and to reservoir pressure differences and then projecting the results into the future has been done successfully in the Wilmington Oil Field, Iong Beach, California. This field probably has been the subject of more subsidence studies than any other underground fluid reservoir in the world. As part of the present work, discussions were held with Dennis Allen, Subsidence Control Engineer, Dept. of Oil 
Properties, City of Iong Beach, regarding past studies of subsidence and the current central program in the wilmington Field.

One is led to the conclusion that reliable estimates of future subsidence in the area of the Heber Geothermal reservoir cannot be made until the reservoir has been operated for a period of time and the corresponding land survey results studied. Without this information, results from computer models are considered to be the next best source of information available, provided that the reservoir parameters used properly represent the reservoir. Choice of such parameters is indeed a major problem. All the physical parameters such as the elastic properties of the reservoir rock, distribution of the in-situ stresses, etc. are not yet known for the Heber area. Hence, it was not considered worthwhile preparing such a model. However, Chevron Oil Company is attempting to develop such a model of Heber; their preliminary results indicate that subsidence due to production at Heber will be small and should pose no serious problem, according to Mr. Iloyd Mann in a personal commmication in July 1976.

There are few other means for estimating future subsidence. One such method has been discussed by Geertsma (19) and by Raghaven and Miller (51). This method is applied in the next section of the present report to obtain an approximate extimate of possible subsidence in the Heber area.

\section{Estimation of Compaction and Subsidence}

In operating the Heber reservoir, the rate of fluid injection and fluid production has been assumed to be the same. Assuming the overburden pressure to be fixed, this means that any resulting rock compaction and subsidence would 
be attributable only to the pressure drawdowns causing flow toward the producing wells, and hence subsidence, if any, should, occur only in the vicinity of the producing wells.

According to Geertsma (19), if the lateral dimension of a reservoir are large compared to its thickness, then it will deform predominantly in the vertical plane. A uniaxial compaction coefficient, $q \dot{m}$, is defined as the formation compaction per unit change in pore pressure (fluid pressure) reduction:

$$
q_{n}=\frac{1}{z} \frac{d p}{d z}
$$

in which $\mathrm{z}$ is the vertical coordinate and $\mathrm{p}$ the fluid pressure.

Assuming that a fixed value can be assigned to $c_{m}$ for the fluid pressure range of interest, equation [1] can be integrated to yield:

$$
\Delta \mathrm{H}=\mathrm{c}_{\mathrm{m}} \cdot \Delta \mathrm{p} \cdot \mathrm{H}
$$

in which $\Delta p=\left(p_{i}-p\right)$ is the drop in fluid pressure from its initial value, and $\mathrm{H}$ is the initial thickness of the reservoir, $\mathrm{H}$ is the compaction.

Geonomics' Report (20) indicates that the reservoir pressure drop due to the production of water for a $200 \mathrm{MN}$ plant will be of the order of 6.8 - $20.4 \mathrm{~atm}$ (100 to 300 psia) around the well bores. Away from the wells, pressure drop will be much smaller. An average value in the entire reservoir for $\Delta p$, in equation [2], should be less than 6.8 atm (100 psia). In the same report the overall net productive thickness of the reservoir, $H$, is taken as $734 \cdot \mathrm{m}(2,408 \mathrm{ft})$ for the pressure analysis made there. This value can be assigned to $\mathrm{H}$ in equation [2]. 
Coefficient $c_{m}$ can be estimated with Geertsma's equation (19) put in the form:

$$
c_{m}=\frac{1}{3} \frac{(1+v)}{(1-v)} \quad\left(c_{b}-c_{r}\right)
$$

in which $\mathrm{v}=$ Poisson's ratio, assumed 0.2 for the Heber reservoir; $\mathrm{g}_{\mathrm{b}}=4.9 \times 10^{-5} \mathrm{~cm}^{2} / \mathrm{kg}\left(3.4 \times 10^{-6} \mathrm{in}^{2} / \mathrm{lb}\right)$ from Table No. 8 cited above; and $c_{r}=0.16 \times 10^{-5} \mathrm{~cm}^{2} / \mathrm{kg}\left(0.112 \times 10^{-6} \mathrm{in}^{2} / 1 \mathrm{~b}\right)$, assumed the same as for quartz. Substituting in equation [3]:

$$
c_{\mathrm{m}}=2.37 \times 10^{-5} \mathrm{~cm}^{2} / \mathrm{kg}\left(1.65 \times 10^{-6} \mathrm{in}^{2} / \mathrm{lb}\right)
$$

$$
\text { -.... [4] }
$$

Returning to equation [2] and substituting for $c_{m} \Delta p$, and $H$, the compaction is given by:

$$
\Delta \mathrm{H}=0.12 \mathrm{~m}(0.4 \mathrm{ft})
$$

If the reservoir is assumed to have the shape of a cylindrical disc of constant thickness with its axis vertical, the subsidence can be estimated using the equation (51):

$$
u_{z}=-2 c_{m}(1-v) \Delta p \cdot H\left(1+\frac{n}{1+n^{2}}\right)
$$

in which $u_{z}$ is the subsidence, and $n$ the ratio of the reservoir depth to its radius, D/R. In applying equation [6], the cylindrical disc reservoir is assumed to be isolated from its surroundings by an impermeable barrier. The entire reservoir is considered to behave as a tank with fluid withdrawal taking place uniformly throughout the system. In the present instance, $D=610 \mathrm{~m}(2,000 \mathrm{ft})$ and $R=6.44 \mathrm{~km}(4 \mathrm{mi})=6,440 \mathrm{~m}(21,120 \mathrm{ft})(20)$. 
Hence, $n=(D / R)=(610 / 6,440)=0.0947$. Substituting numerical values in equation [6] the subsidence is given by:

$$
u_{z}=-0.21 m(-0.7 f t)
$$

The parameters used in these compaction and subsidence calculations are gross estimates. Considering this plus the idealized reservoir assumed, the calculated average value of $-0.21 \mathrm{~m}(-0.7 \mathrm{ft})$ is at best only an indication of the possible true magnitude, but is believed to be conservative. The true average value probably is less. The subsidence possibility is minimal over most of the reservoir, but localized subsidence around the producing wells can be significant. A better estimate cannot be made with the cited Geertsma method until better values of the parameters are available. Moreover, the method of analysis used here does not account for the variation of drawdown pressures with time or for any time lag in subsidence. 


\section{CONCLUSIONS AND RECOMMENDATIONS}

1. Geothemal development at Heber is not likely to have any adverse impact on the shallow ground water resource of the area.

2. Corrosion, scaling and presence of noncondensable gases should prove to be minimal for the Heber geothermal project.

3. The Heber area lies in a general region of high seismicity and strain release.

- 4. No fault has yet been mapped directly under the Heber area. The stress condition and the strength of the rocks at Heber are not known. Until such data are available, it is difficult to assess the possibility of increased seismicity due to geothermal activity.

5. The Heber area is subsiding and tilting northeastward due to tectonic causes. The subsidence is not great and should present no serious problems at its present rate; however, leveling surveys have shown that the rates are not constant.

6. Geothermal development activity at Heber should have a small effect on subsidence compared to that due to existing tectonic causes. 
7. Design of the structures should take into account acceleration and resonance spectra which are available for the 1940 earthquake. A combined local soil test analysis and seismic structural response should be made as part of any detailed structural design. The design acceleration recommended should be no less than ..375 $\mathrm{g}$.

8. Baseline data should be obtained by monitoring the Heber area for seismicity and subsidence before power production begins. It is also desirable to have a permanent monitoring system throughout the life of the power plant. 


\section{BIBLTOGRAPHY}

1. Allen, C.R., "Environmental Aspects of Oil and Producing Operations, Iong Beach, California", Society of Petroleum Engineers of ATME Preprint No. SPE $3450,1971$.

2. Allen, C.R., St. Amand, P., Richter, D.F., and Nordquist, J.M., "Relation Between Seismicity and Geologic Structure in the Southern California Region", Bulletin of Seism. Soc. Am., No. 55, pp 753-797, 1965.

3. Allison, E.C., "Geology of Areas Bordering Gulf of Califormia - A Symposium", American Association of Petroleum Geologists, Mem. 3, pP 3-29, 1964.

4. Bird, D., "Geology and Geochemistry of the Dunes Hydrothermal System, Imperial Valley of Califomia", Master's Thesis, University of California, Riverside, 1975.

5. Biehler S., Kovach, R.L., and Allen, C.R. , "Geophysical Framework of the Northern End of the Gulf of California Structural Province", "Marine Geology of Gulf of Califormia", T. Van Andel and G. Shor, eds. , American Association of Petroleum Geologists, Mem. 3, pp 126-296, 1964.

6. Biehler S., "Gravity Studies in the Imperial Valley", Cooperative Geological-Geophysical-Geochemical Investigations of Geothenmal Resources in the Imperial Valley of California, R. W. Rex, Principal Investigator, University of California, Riverside, pp 29-43, 1971.

7. Brune, J.N., and Allen, C.R., "A Microearthquake Survey of the San Anareas Fault System in Southern California", Bulletin of Seism. Soc. Am., Vol. 57, pp 277-296, 1967.

8. Burley, J.D., "A Solution to Ground Subsidence Problems in Casing Strings and Well Heads", Journal of Petroleum Technology, 1971.

9. Califomia Department of Water Resources, "Geothermal Wastes and the Water Resources of the Salton Sea Area", Bulletin, Vol. 143, No. $7,1970$. 
10. Cloud, W.K., "Maximum Acceleration During Earthquakes", Proceedings, Chilean Conference on Seismology and Earthquake Engineering, Vol. I, University of Chile, July, 1963.

11. Cambs, J., "Heat Flow and Geothermal Resource Estimates for the Imperial Valley" , in Cooperative Geological-Geophysical-Geochemical Investigations of Geothermal Resources in the Imperial Valley Area of California, R. W. Rex, Principal Investigator, University of California, Riverside, pp 119-124, 1971.

12. Cambs, I., and Hadley, D.M., "Microearthquake Investigations of the Mesa Geothermal Anomlay, Imperial Valley, California", Gegphysics, Vol. 39, 1974.

13. Dibblee, T.W., "Geology of the Imperial Valley Region, Geology of Southern California", California Division of Mines Bulletin, 170, pp 21-28, 1954.

14. Donovan, N., "Earthquake Hazards for Buildings: Building Practices for Disaster Mitigation", Building Science Series, 46, Nat. Bureau of Standards, U.S. Department of Commerce, Washington, D.C, , pp 82-111, 1973.

15. Duke, C.M., and Leeds, D.J., "Site Characteristics of Southern California Strong Motion Earthquake Station, Report No. 62-55", Department of Engineering, University of California, Ios Angeles, California, 1962.

16. Dutcher, L.C., Hardt, W.F., and Moyle, W.R., Jr., "Preliminary Appraisal of Ground Water in Storage with Reference to Geothermal Resources in the Imperial Valley Area, California", U.S. Geological Survey Circular 649, 1972.

17. Elders, W.A., Rex, R.W., Meidav, T., Robinson, P.T., and Biehler, S., "Crustal Spreading in Southern California", Science, 178, pp 15-24, 1972.

18. Garfunkel. Z., "The Tectonics of the Salton Trough of California", Cooperative Investigations of Geothermal Resources in the Imperial Valley Area and Their Potential Value for Desalting of Water and Other Purposes, R. W. Rex, Ed., University of California, Riverside, pp Hl-H3, 1972 . 
19. Geertsma, J., "Iand Subsidence Above Compacting Oil and Gas Reservoirs", Journal of Petroleum Technology, June, 1973.

20. Geonomics, Inc., "Feasibility Study for a Low Salinity Hydrothermal Demonstration Plant, Reservoir Engineering Report, Phase II", Submitted to Electrical Power Research Institute for Holt/Procon, April 23, 1976.

21. Goldsmith, M., "Geothermal Resources in California, Potentials and Problems", California Institute of Technology, Environmental Quality Lab. Report No. 5, 1971.

22. Halton, J.W., "Ground Subsidence of a Geothermal Field During Exploration", Geothermics, Special Issue 2, pp 1294-1296, 1970.

23. Hamilton, W., "Origin of the Gulf of California", Geological Society of America Bulletin, Vol 72, 1961.

24. Helgeson, H.C., "Geologic and Thermodynamic Characteristics of the Salton Sea Geothermal System", American Journal of Science, Vol. 266, pp 129-166, 1968.

25. Hileman, J.A., Allen, C.R., and Nordquist, J.M., "Seismicity of the Southern California Region: 1 January, 1932 to 31 December, 1972", Seismological Laboratory Bulletin, C.I.T., Pasadena, California, 1973.

26. Hill, D., Mowinckel, P., and Lahr, "Catalog of Earthquakes in the Imperial Valley, California, June 73-May 74", U.S.G.S. Open File Report, Washington, D.C., 1975.

27. Hill, D., Mowinckel, P., and Peake, I. "Earthquakes, Active Faults, and Geothemal Areas in the Imperial Valley, Califomia", Science, 188, pp $1306-1308,1975$.

28. Housner, G.W., "Intensity of Earthquake Ground Shaking Near the Causative Fault", Proceedings, 3rd World Conference on Earthguake Engineering, New zealand, Vol. 1, 1965.

29. Jacquin, C., and Poulet, M.J., "A Study of the Hydrodynamic Pattern in a Sedimentary Basin Project to Subsidence", Society of Petroleum Engineers of ATME Preprint No. SPE 2988, 1970.

30. Jahns, R.H., "Investigations and Problems of Southern Califomia Geology", California Division of Mines Bulletin, 170, pp 5-29, 1954. 
31. Johnson, C.E., and Hadley, D.M., "Tectonic Implications of the Brawley Earthquake Swarm, Imperial Valley, California", Seismological - Laboratory, California Institute of Technology, Pasadena, California, 1975.

32. Johnson, D., and Hanks, T., "Strong-Motion Accelerograms of the Brawley Swarm: January 25, 1975", Bulletin of Seism. Soc. Am., 65. December, 1975.

33. Koenig, J.B., "Geothermal Resources in California", California Division of Mines and Geology, Mineral Information Service, Vol. 19, No. 6, pp 94-95, 1966.

34. - "The Salton Mexicali Geothermal Province", California Division of Mines and Geology, Mineral Information Service, Vol. 20, pp 2845-2871, 1967.

35. Kovach, R. L., Allen, C.R., and Press, F., "Geophysical Investigations in the Colorado Delta Region", Journal of Geophysical Research, Vol. 67, pp 2845-2871, 1962.

36. Lange, A.L., "Microearthquakes in Geothermal Prospecting", Amax Exploration, Inc., Annual Meeting of the Society of Econamic Geologists, Miami, Florida, November 18, 1974.

37. Leeds, D.J., "The Design Earthquake, in Geology, Seismicity, and Environmental Impact", Association of Engineering Geologists, Special Publication, D.E. Moran, J.E. Slosson, R.O. Stone, and

. C.A. Yelverton, eds., pp 337-347, 1973.

38. Loeltz, O.J., Irelan, B., Robinson, J.H., and Olmstead, F.H., "Geohydrologic Reconnaisaance of the Imperial Valley, California", Geological Survey Professional Paper 486-K, 1975.

39. Lofgren, B.E., "Measuring Ground Movement in Geothermal Areas of Imperial Valley, California", Proceedings of the Conference on Research for the Development of Geothermal Energy Resources, Pasadena, California, pp 128-133, September (23-25), 1974.

40. Iamitz, C., Mooser, F., Allen, C.R., Brune, J.N., and Thatcher, W., "Seismicity of the Gulf of California Region, Mexico -- Preliminary Results", Geofisica Internacional, Vol.10, 1970. 
41. Longwell, C.R., "History of the Lower Colorado River and Imperial Depression, Geology of Southern California"., Part 9, Chapter. 5, California Department of Natural Resources, Division of Mines Bulletin, 170, pp 53-56, 1954.

42. Meidav, T., and Furgerson, R., "Resistivity Studies of the Imperial

- Valley Geothermal Area, California", Geothermics, Vol. I, pp 47-62, 1972.

43. Meidav, H.T. and Rotstein, Y., "A Structural Gravity Model for the Imperial Valley", (unpublished), 1971.

44. Meidav, H.T., James, R., and Sanyal, S.K., "Utilization of Gravimetric Data for Estimation of Hydrothermal Reservoir Characteristics in the East Mesa Field, Imperial Valley, California", Stanford Geothermal Program (NSF) Workshop on Geothermal Reservoir - Engineering, SAP-TR-12, December 15-17, 1975.

45. Merriam, R., and Bandy, O.L., "Source of Upper Cenozoic Sediments in Colorado Delta Region", Journal of Sedimentary Petrology, Vol. 35, PP 911-916, 1965.

46. Miller, R.W., Pope, A.J., Staltner, H.S., and David, J.L., "Crustal Movement Investigations -- Triangulation", Imperial Valley, Operational Data Report DGS DR-10, Coast and Geodetic Survey, U.S. Department of Commerce, Rockville, Maryland, 1970.

47. Muffler, L.J.P., and Doe, B.R., "Composition and Mean Age of Detritus of the Colorado River Delta in the Salton Trough, Southeastern California", Journal of Sedimentary Petrology, Vol. 38, pp 384-399, 1968.

48. Nordquist, J.M., "A Catalog of Southern California Earthquakes and Associated Electronic Data Processing", Bulletin of Seism. Soc. Am., Vol. 54, pp 1003-1011, 1964.

49. Olmstead, F.H., Loeltz, O.J., and Irelan, B., "Geohydrology of the Yuma Area, Arizona and California", U.S.G.S. Professional Paper $486-\mathrm{H}, 1972$.

50. Poland, J.F., "Underground Waste Management and Environmental Implications", American Association of Petroleum Geologists, Memoir 18, 1972. 
51. Raghaven, R., Miller, F.G., "Mathematical Analysis of Sand Campaction", Compaction of Coarse-Grained Sediments I, G. V. Chillingarian and K.H. Wolf, eds., Developments in sedimentology $18 \mathrm{~A}$, Elsevier Scientific Publishing Co., New York, pp 403-524, 1975.

52. Raleigh, C.B., Healy, T.H., and Bredehoff, J.D., "Faulting and crustal Stress at Rangely, Colorado", Flow and Fracture of Rocks, Geophysical Monograph, 16, pp 275-285, 1972.

53. Randall w., "Percent Volume Sand Bodies in the Imperial Valley (Preliminary Report)" , Cooperative Geological-GeophysicalGeochemical Investigations of Geothermal Resources in the Imperial Valley Area of Califormia, R.W. Rex, Principal Investigator, University of California, Riverside, pp 119-124, 1971.

54. - "An Analysis of the Subsurface Structure and Stratigraphy of the Salton Sea Geothermal Ancmaly, Imperial Valley, California", Ph.D. Dissertation, University of California, Riverside, December, 1974.

55. Rex, R.W., Babcock, E.A., Biehler, S., Cambs, J., Coplen, T.B., Elders, W.A., Furgerson, R.B., Garfunke., Z., Meidav, T. , and Robinson, P.T., "Cooperative Geological-Geophysical-Geochemical Investigations of Geothermal Resources in the Imperial Valley Area of California", University of California, Riverside, 1971.

56. Rex, R.W., Biehler, S., Cambs, J., Coplen, T.B., Furgerson, R.B., Garfunkel, Z., Getts, T., Maas, J., and Reed, M., "Cooperative Investigation of Geothermal Resources in the Imperial Valley Area and Their Potential Value for Desalting of Water and Other Purposes", Institute of Geophysics and Planetary Physics, University of California, Riverside, 1972.

57. Rex, R.W., "Investigation of Geothermal Resources in the Imperial Valley and Their Potential Values in Desalination of Water and Electricity Production, A Study in Resource Management", University of California Press, pp 190-205, 1971.

58. Richter, C.F., and Gutenberg, B., "Seismicity of Southem Califomia", Bulletin of the California Division of Mines, 170, Chapter 4, 1954.

59. Richter, C.F., "Elementary Seismology", W.H. Freeman and Company, Inc. 1958.

60. Savage, J.C., Goodrean, D., and Prescott, W.H., "Possible Fault Slip on the Brawley Fault, Imperial Valley, California", Bulletin of Seism. Soc. Am., 64, pp 713-715, 1974. 
61. Schnabel, P.B., Seed, H.B., "Accelerations in Rock for Earthquakes in the Western United States", E.Q. Engineering Research Center Report, 72-2, 1972.

62. Scholz, C.H., and Fitch, T.J., "Strain Accumulation Along the San Andreas Fault", Journal of Geophysical Research, Vol. 74, No. 27, 1969.

63. Seed, H.B., Irdriss, I.M., and Kiefer, F.W., "Characteristics of Rock Motions During Earthquakes", FERC Report No. 68-6, 1968.

64. Sharp, R.V., "Tectonic Salting of the Salton Trough in the Borrego Mountains Earthquake of April 9, 1968", U.S.G.S. Professional Paper No. 787, 1972.

65. Swanberg, C.A., "The Mesa Geothermal Anomaly, Imperial Valley, California: A Comparison and Evaluation of Results Obtained from Surface Geophysics and Deep Drilling", submitted for publication, Proceedings of the Second United Nations Symposium on the Development and Use of Geothermal Resources, San Francisco, California, May 20-29, 1975.

66. Telectyne Geotech, "Geothermal Noise Survey of the Heber Area of Imperial County", California Technical Report 72-2, 1972.

67. Ulrich, F.P., "The Imperial Valley Earthquakes of 1940", Bulletin of Seism. Soc. Am., Vol. 31, pp 13-31, 1941 .

68. Van Kamp, P.C., "Holocene continental Sedimentation in the Salton Basin, California, A Reconnaissance", Geological society of America Bulletin, Vol. 84, pp 827-848, 1973.

69. Ward, P.I., "Microearthquakes: Prospecting Tool and Possible Hazand in the Development of Geothermal Resources", Geothermics, Vol 1, No. 1, pp 3-13, 1972.

70. Whitten, C.A., "Crustal Movement in California and Nevada", American Geophysical Union Transactions, Vol. 37, No. 4, pp 393-398, 1956.

71. - "Measurements of Earth Movements in Califomia", California Division of Mines Bulletin, 171, pp 75-80, 1955.

72. - "Horizontal Movements in the Earth's Crust", Joumal of Geophysics, Res. 65, Pp 2839-2844, 1960. 